INSTITUTO DE PESQUISAS ENERGÉTICAS E NUCLEARES

Autarquia associada à Universidade de São Paulo

CLONAGEM, EXPRESSÃO, PURIFICAÇÃO E CARACTERIZAÇÃO ESTRUTURAL DA PROTEÍNA RIBOSSOMAL L10 HUMANA RECOMBINANTE

LARISSA MIRANDA PEREIRA

São Paulo

2009 


\section{INSTITUTO DE PESQUISAS ENERGÉTICAS E NUCLEARES}

Autarquia associada à Universidade de São Paulo

Clonagem, Expressão, Purificação e Caracterização Estrutural da Proteína

Ribossomal L10 Humana Recombinante

\section{Larissa Miranda Pereira}

Dissertação apresentada como parte dos requisitos para obtenção do Grau de Mestre em Ciências na Área de Tecnologia Nuclear - Aplicações.

Orientadora:

Dra Regina Affonso

São Paulo 
Aos meus pais, Nuno e Vera, com todo amor e carinho. 


\section{Agradecimentos}

Agradeço primeiramente à minha orientadora Dra. Regina Affonso, pelos ensinamentos de Biologia Molecular, pela amizade, por todo incentivo, apoio e paciência, principalmente nas horas mais difíceis, por ter confiado em mim e por todos os ensinamentos que ultrapassaram a Biologia Molecular.

À Dra. Ligia Ely Morganti Ferreira Dias, pelo uso de seu laboratório, pela colaboração na expressão da proteína QM com suas enriquecedoras sugestões e por todas as discussões sobre o trabalho.

A Dra. Dulce E. Casarini, da Universidade Federal de São Paulo (UNIFESP), por permitir utilizar toda a infra-estrutura de seu laboratório, o que foi essencial para a obtenção dos resultados.

Ao Dr. Patrick Jack Spencer, pelos ensinamentos, pela paciência e por toda ajuda com a purificação da proteína.

À Dra. Maria Teresa C. P. Ribela, pela ajuda e sugestões com a purificação da proteína.

À Dra. Nanci do Nascimento, gerente do Centro de Biotecnologia, pelo apoio.

Ao grupo de Hormônios do Centro de Biotecnologia pela utilização de toda infraestrutura.

À Dra. Nélida, do Instituto de Química - USP, por toda ajuda com os ensaios de dicroísmo circular.

À Dani Aragão, do laboratório da Dra. Dulce, da UNIFESP, pela ajuda com a exclusão molecular. 
À amiga Natália Malavasi, pela amizade conquistada, risadas, conversas na copa, por toda ajuda no laboratório, por todas as discussões científicas, pela paciência e por me ajudar, especificamente, nos ensaios de fluorescência.

À amiga Karina Corleto, pela amizade, por todos os momentos bons, almoços, conversas, risadas e ajuda no laboratório e, especificamente, por me ajudar na purificação da proteína.

Aos amigos, Danielle Borim, Rosa Maria Chura-Chambi, Juliana Branco Novo, Camila Miyagui Yonamine, Keli Nunes Balduino, por todos os bons momentos e discussões científicas.

Às amigas Bruna e Jose, por compartilharem comigo bons momentos no laboratório, por toda a ajuda e interesse.

Às amigas, Rê, Bia e Eliza, pelos bons momentos no IPEN.

Aos funcionários e amigos, Edu, Johnny, Junqueira, Rute e Arlete, sempre dispostos a ajudar.

A todos os funcionários e amigos do IPEN, principalmente, Dona Gê e Seu Longino, pela manutenção e organização do laboratório.

Aos meus pais, Nuno e Vera, pelo amor incondicional, pelo interesse, incentivo, confiança, respeito, por proporcionarem toda a tranqüilidade para a realização deste trabalho, pela paciência, pela luta de vocês, por estarem sempre por perto.

À minha irmã Ana Paula, pelo seu amor, carinho, apoio e por alegrar a minha vida.

Ao Guilherme, pela paciência, confiança, interesse, por me ajudar em toda a confecção deste trabalho, pela leitura dos textos, pelos comentários e sugestões e por todos bons momentos juntos. 
À amiga Camila Keiko Takahashi, Keiko, que está bastante longe fisicamente, mas, que me ajudou muito neste trabalho, não só lendo, comentando e pontuando sugestões, mas me incentivando o tempo todo com palavras carinhosas. Obrigada por sua amizade, pelo seu carinho, por tudo!

Ao amigo Eduardo Baer, "Almeida", pelo seu interesse no meu trabalho, sempre perguntando alguma coisa...Obrigada por ler e me ajudar com o Abstract.

Às amigas/irmãs Pitú, Dai, Fefa, Fer, Natty, Tata, Vâ e Vívian, pela amizade, pelo amor, por estarem sempre por perto, pelo interesse, pelas palavras de incentivo, por todo carinho e por me fazerem mais feliz. 


\title{
CLONAGEM, EXPRESSÃO, PURIFICAÇÃO E CARACTERIZAÇÃO ESTRUTURAL DA PROTEÍNA RIBOSSOMAL L10 HUMANA RECOMBINANTE
}

\author{
Larissa Miranda Pereira
}

\section{RESUMO}

A proteína ribossomal L10 (RP L10) é uma forte candidata a ser incluída na classe de proteínas supressoras de tumor. Também denominada QM, a proteína em questão é conhecida por participar da ligação das subunidades ribossomais $60 \mathrm{~S}$ e $40 \mathrm{~S}$ e da tradução de mRNAs. Possui massa molecular entre 24 a 26 kDa e ponto isoelétrico (pl) 10,5. A seqüência da proteína QM é bastante conservada em mamíferos, plantas, invertebrados, insetos e leveduras indicando que esta possui funções críticas na célula. Com função supressora de tumor, a proteína RP L10 foi estudada em linhagens de tumor de Wilm (WT-1) e em células tumorais de estômago, nas quais se observou uma diminuição na quantidade de seu mRNA. Mais recentemente a RP L10 foi encontrada em baixas quantidades nos estágios iniciais de adenoma de próstata e com uma mutação em câncer de ovário, indicando uma participação no desenvolvimento destas doenças. Como proteína, já foi descrito que esta interage com as proteínas c-Jun e c-Yes, inibindo a ação ativadora de fatores de crescimento e divisão celular. Este trabalho tem um papel importante no estabelecimento da expressão desta proteína solúvel, para estudos posteriores que tenham como objetivo avaliar a ação de regiões específicas que atuam na ligação das subunidades ribossomais $60 S$ e $40 S$ e tradução, bem como nas regiões que se ligam a proto-oncogenes. $O$ cDNA para proteína QM foi amplificado por PCR e clonado no vetor de expressão periplásmica p3SN8. A proteína QM foi expressa em E.coli BL21 (DE3) no citoplasma e periplasma bacteriano e na melhor condição, a expressão de QM de bactérias transformadas pelo plasmídeo recombinante p1813_QM em 25 ou $30^{\circ} \mathrm{C}$, a proteína foi obtida solúvel e com quantidades muito pequenas de contaminantes. Os ensaios de estrutura secundária demonstraram que a proteína QM tem predominância de $\alpha$-hélice, mas quando do seu desenovelmento, essa condição muda e a proteína passa a ter característica de folhas $\beta$. 


\title{
CLONING, PERIPLASMIC EXPRESSION, PURIFICATION AND STRUCTURAL CHARACTERIZATION OF HUMAN RIBOSOMAL PROTEIN L10 RECOMBINANT
}

\author{
Larissa Miranda Pereira
}

\begin{abstract}
The ribosomal protein L10 (RP L10) is a strong candidate to be included in the class of tumor suppressor proteins. This protein, also denominated as $\mathrm{QM}$, is known to participate in the binding of ribosomal subunits $60 \mathrm{~S}$ and $40 \mathrm{~S}$ and the translation of mRNAs. It has a molecular weight that varies between 24 and 26 $\mathrm{kDa}$ and an isoelectric point of $(\mathrm{pl}) 10.5$. The sequence of the protein $\mathrm{QM}$ is highly conserved in mammals, plants, invertebrates, insects and yeast which indicates its critical functions in a cell. As a tumor suppressor, RP L10 has been studied in strains of Wilm's tumor (WT-1) and tumor cells in the stomach, where was observed a decrease in the amount of its mRNA. More recently, the RP L10 was found in low amounts in the early stages of prostate adenoma and showed some mutation in ovarian cancer, what indicates its role as a suppressor protein in the development of these diseases. It has also been described that this protein interacts with c-Jun and c-Yes inhibiting growth factors and consequently, cell division. This work has an important role on the establishment of soluble expression of QM to give base information for further studies on expression that aim to evaluate the specific regions where it acts binding the $60 \mathrm{~S}$ and $40 \mathrm{~S}$ ribossomal subunits and translation, as well as its binding to proto-oncogenes. The CDNA for QM protein was amplified by PCR and cloned into periplasmic expression vector p3SN8. The QM protein was expressed in E. coli BL21 (DE3) in the region of cytoplasm and periplasm, the best condition was obtained from the expression of the recombinant plasmid QM p1813_QM at $25^{\circ} \mathrm{C}$ or $30^{\circ} \mathrm{C}$, the soluble protein was obtained with small amounts of contaminants. The assays of secondary structure showed that the QM protein is predominantly alpha-helix, but when it loses the folding, this condition changes and the protein is replaced by $\beta$ sheet feature.
\end{abstract}




\section{SUMÁRIO}

1 INTRODUÇÃO

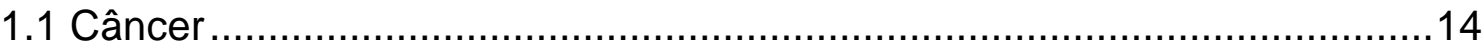

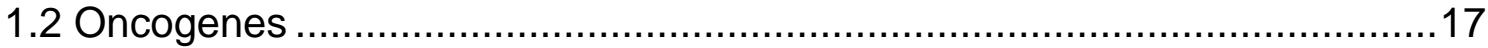

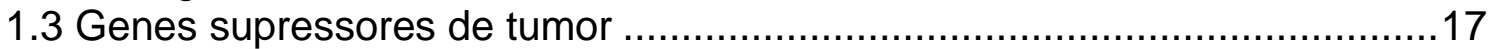

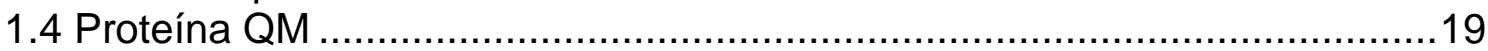

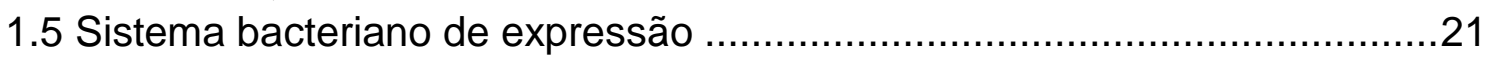

2 OBJETIVOS

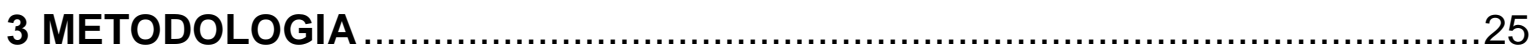

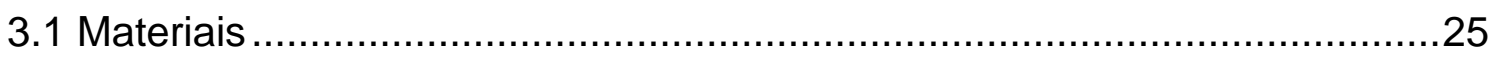

3.1.1 Equipamentos e acessórios principais ...........................................25

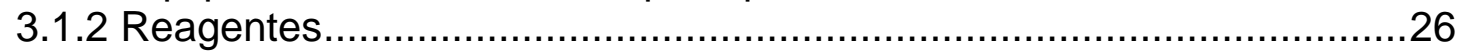

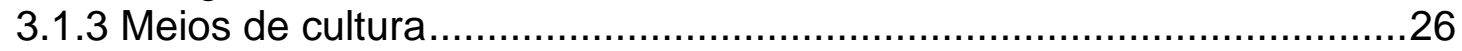

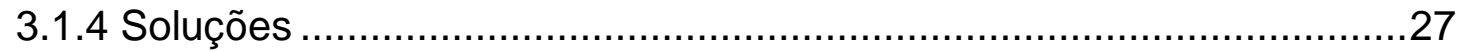

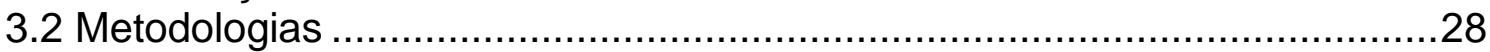

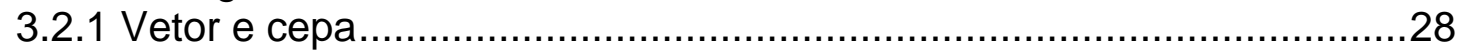

3.2.1.1 Vetor de expressão bacteriano...............................................28

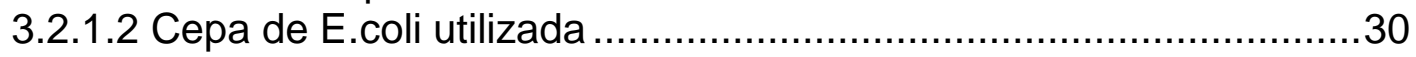

3.2.2 Amplificação dos plasmídeos........................................................30

3.2.2.1 Preparação dos plasmídeos .....................................................30

3.2.2.2 Remoção de proteínas e RNA (extração do DNA com limpeza por fenol) ................................................................................

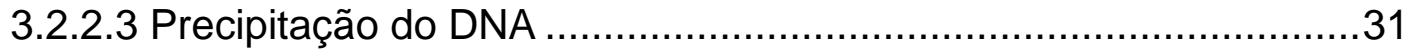

3.2.2.4 Eletroforese em gel de agarose................................................32

3.2.2.5 Separação e purificação de DNA .............................................32

3.2.2.6 PCR para amplificação do gene da proteína QM ...........................32

3.2.2.7 Reação de ligação de DNA ......................................................33

3.2.2.8 Preparo de bactérias competentes ...............................................33

3.2.2.9Transformação de bactérias E.coli ...............................................34

3.2.3 Expressão da proteína recombinante ..............................................34

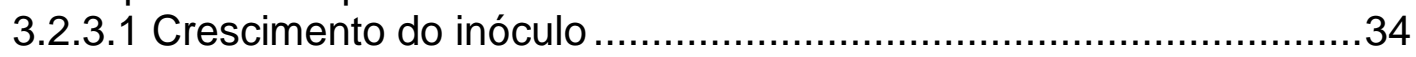

3.2.3.2 Ativação com adição de IPTG ....................................................35

3.2.3.3 Extração da proteína heteróloga QM por choque osmótico ............35

3.2.3.4 Extração da proteína recombinante por lise celular por sonicador.36

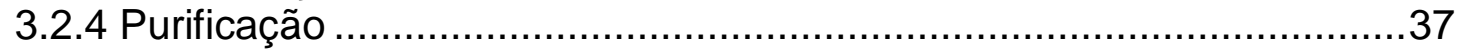

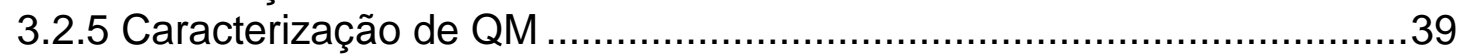

3.2.5.1 Eletroforese em gel de poliacrilamida (SDS-PAGE) .......................39

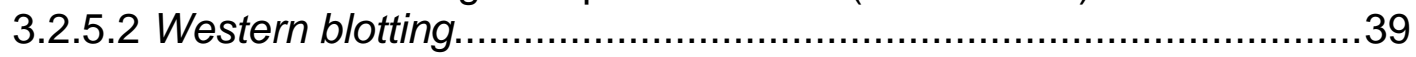

3.2.6 Dosagem de QM expressa pelos vetores ..........................................40

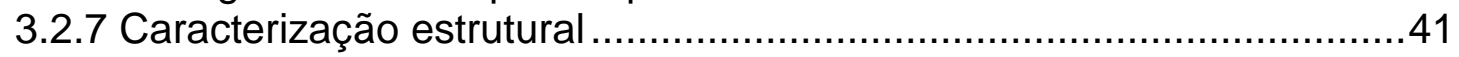

3.2.7.1 Dicroísmo circular (CD) ...................................................... 41

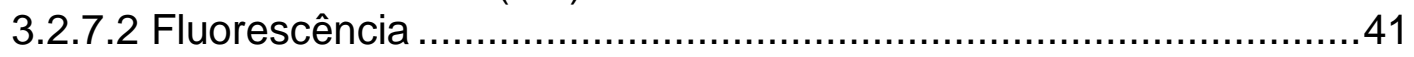

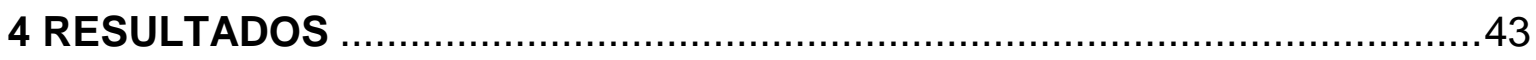

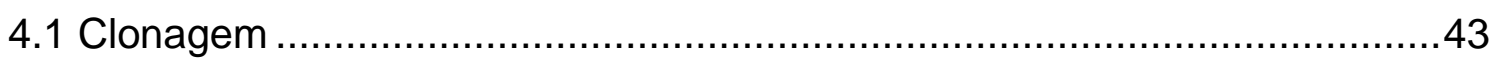

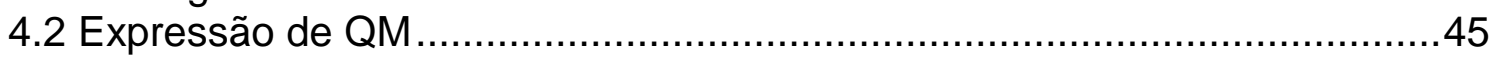


4.2.1 Padronização das condições de ativação na expressão da proteína humana recombinante $\mathrm{QM}$

4.2.1.1 Expressão Periplásmica .........................................................45

4.2.1.2 Expressão Citoplásmica .......................................................47

4.2.2 Extração da proteína QM recombinante do espaço periplásmico .........48

4.2.3 Quantificação de QM ...............................................................52

4.2.3.1 Quantificação de QM produzido pelas bactérias transformados com

o vetor pET26_QM

4.2.3.2 Quantificação de QM produzido pelas bactérias transformadas com

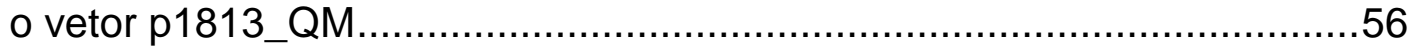

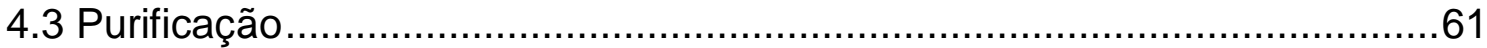

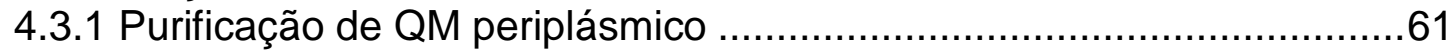

4.3.2 Purificação de QM citoplásmico ......................................................63

4.4 Caracterização estrutural por Dicroísmo Circular ......................................65

4.5 Caracterização de QM por emissão de fluorescência .............................72

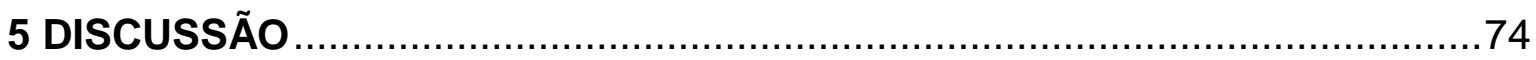

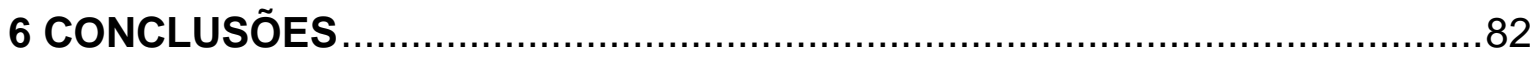

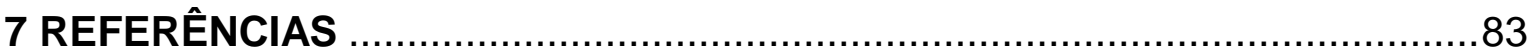




\section{ÍNDICE DE FIGURAS}

FIGURA 1: Capacidades adquiridas pelo câncer (Hanahan \& Weinberg, 2000). .15 FIGURA 2: Proteínas Supressoras de Tumor (a) p53 e (b) pRb e suas funções no ciclo celular e apoptose (Godefroy e cols., 2006)..............................................19 FIGURA 3: Esquema da parede bacteriana de E. coli. (modificado de vários autores).....

FIGURA 4: Vetores de expressão periplásmica (a) pET26b (Novagen), (b) p3SN8 e citolplásmica (c) p1813 com seus respectivos sítios de clonagem. ....................29

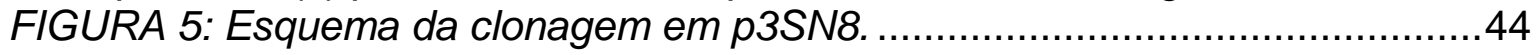
FIGURA 6: Inserto e vetor p3SN8..............................................................4 FIGURA 7: Análise da expressão da proteína QM por SDS_PAGE (a) e Western blotting (b).

FIGURA 8: Expressão de QM por bactérias transformadas com pET26_QM a 30 C por 16 horas.

FIGURA 9: Expressão de QM citoplasmático em bactérias transformadas com p1813 em diferentes temperaturas de ativação. ...............................................47

FIGURA 10: Análise de Western blotting das frações periplásmicas.

FIGURA 11: Análise de Western blotting das frações periplásmicas.

FIGURA 12: Análise em Western blotting de QM produzido por bactérias ativadas com IPTG a $30^{\circ} \mathrm{C}$ por 16 horas.

FIGURA 13: Análise em SDS-PAGE de QM com ultracentrifugação...

FIGURA 14: Gel de SDS-PAGE com amostras da expressão de QM pelas bactérias transformadas pelo vetor pET26_QM, utilizado para quantificação por Bradford.

FIGURA 15: Curva de concentração de albumina para padronização do ensaio de

Bradford.

FIGURA 16: Imagem dos gráficos gerada a partir do programa ImageJ. .55

FIGURA 17: Gel de SDS-PAGE com amostras de expressão de QM produzido pelas bactérias transformadas com o vetor p1813_QM em diferentes temperaturas de ativação utilizado na quantificação de proteínas solúvel pelos métodos de Bradford e ImageJ.

FIGURA 18: Expressão da proteína QM pelas bactérias transformadas com o vetor recombinante $p 1813$ Q $Q M$ ativadas a temperatura de $25^{\circ}$.

FIGURA 19: Expressão de QM em SDS-PAGE nas temperaturas de $25^{\circ} \mathrm{C}$ e $30^{\circ} \mathrm{C}$.

FIGURA 20: Análise da purificação com íons Ni e Co.

FIGURA 21: Western blotting do ensaio de purificação em troca cationica, coluna

HiTrap SP XL.

HiTrap SP XL. .......................................................................................62

FIGURA 22: Cromatografia de troca catiônica em coluna HiTrap SP XL em

tampão Fosfato de Sódio 50mM pH 7,2.....

FIGURA 24: Perfil da cromatografia por exclusão molecular com amostras da ativação a $30^{\circ} \mathrm{C}$.

FIGURA 25: Cromatografia por Exclusão Molécula em SDS-PAGE....................65

FIGURA 26: Perfil de CD da amostra de QM sp2 expressa a 25C . .....................66

FIGURA 27: Perfil de CD da amostra de QM sp2 expressa a 30 C. ....................67

FIGURA 28: Perfil de estrutura secundária de QM citoplásmico expresso a $25{ }^{\circ}$

por Dicroísmo Circular com acréscimo de guanidina. 
FIGURA 29: Perfil de estrutura secundária de QM citoplásmico expresso a $30{ }^{\circ} \mathrm{C}$ por Dicroísmo Circular com acréscimo de guanidina.

$\mathrm{Na}$ legenda estão as diferentes concentrações de guanidina que foram adicionadas á amostra. 69

FIGURA 30: Curva da emissão de fluorescência do triptofano da amostra de QM citoplásmica ativada a $25^{\circ} \mathrm{C}$ com desnaturação da pro teína por Guanidina. .72 FIGURA 31: Curva da emissão de fluorescência do triptofano da amostra de QM citoplásmica ativada a $25^{\circ} \mathrm{C}$ com desnaturação da pro teína por Guanidina. .73 FIGURA 32: Curva da emissão de fluorescência do triptofano da amostra de QM citoplásmica ativada a $25^{\circ} \mathrm{C}$ com acréscimo de zinco. 


\section{ÍNDICE DE TABELAS}

TABELA 1: Quantificação de QM pelo método de Bradford .56

TABELA 2: Porcentagem de QM na amostra de proteína produzida no citoplasma

TABELA 3: Quantificação de QM pelo método de Bradford

TABELA 5: Modificações na estrutura secundária de QM com acréscimo de guanidina em amostra de QM sp2 expressa a $25^{\circ} \mathrm{C}$

TABELA 6: Modificações na estrutura secundária de QM com acréscimo de 70 guanidina em amostra de QM sp2 expressa a $30^{\circ} \mathrm{C}$ 


\section{LISTA DE ABREVIATURAS E SIGLAS}

Aids

Síndrome da imunodeficiência

adquirida

Amp

Ampicilina

BSA

Albumina bovina sérica

$\mathrm{Da}$

Dalton

DCC

Deleção em carcinoma de cólon

DNA

Ácido desoxirribonucléico

DO

Densidade óptica

dNTPs

Deoxiribonucleotídeos

DNTs

Doenças não transmissíveis

EDTA

Inca

IPTG

ácido etilenodiamino tetra-acético

Instituto Nacional do câncer

Isopropil $\beta$-d-tiogalactosídeo

LB

Meio Luria-Bertani

MM

Massa molecular

OMS

Organização Mundial de Saúde

PBS

PCR

$\mathrm{pl}$

RNA

RNAm

Solução salina tamponada

Reação de polimerização em cadeia

Ponto isoelétrico

Ácido ribonucléico

Ácido ribonucléico mensageiro

RPM

Rotações por minuto

SDS-PAGE

Sodium Dodecyl Sulphate -

Poliacrilamide Gel Electrophoresis

SOC

Meio super ótimo com repressão da catabólitos

WAGR

Tumor de Wilm, aniridia, anomalia

geniturinária e retardo mental

$\mu \mathrm{L}$

microlitros

$\mu \mathrm{g}$

microgramas 


\section{INTRODUÇÃO}

\subsection{Câncer}

Segundo a OMS ${ }^{1}$ (Organização Mundial da Saúde), em 2008, o câncer foi responsável por 7,6 milhões de mortes no mundo, mais do que a AIDS, malária e tuberculose juntas e, de acordo com Seffrin e cols (2009), o câncer caminha para a principal causa de morte no mundo, seguido por doenças do coração e acidente vascular cerebral. O câncer sozinho acusa mais de 5,3 milhões de mortes anualmente em países de classes média e baixa, o que representa mais de $70 \%$ das mortes por câncer no mundo. Em maio de 2009, os líderes das Nações Unidas e a OMS se reuniram em Doha, no Catar, e como conclusão deste encontro foi aprovada uma declaração pedindo a inclusão de Doenças Não Transmissíveis (DNTs) nas discussões mundiais sobre o desenvolvimento, incluindo o câncer e outras doenças nas Metas para o Desenvolvimento do Milênio. Nesta declaração há um pedido de incentivo à comunidade global de saúde para proporcionar um maior nível de atenção e financiamento a essa doença e assim buscar uma nova agenda de saúde global (Seffrin e cols., 2009).

De acordo com o $\operatorname{lnca}^{2}$ (2009), câncer é o nome dado a um conjunto de mais de 100 doenças que têm em comum o crescimento desordenado de células que invadem os tecidos e órgãos, podendo espalhar-se (metástase) para outras regiões do corpo. Dividindo-se rapidamente, estas células tendem a ser muito agressivas e incontroláveis, determinando a formação de tumores (acúmulo de células cancerosas) ou neoplasias malignas.

É uma doença extremamente heterogênea: tumores em diferentes tecidos mostram diferentes comportamentos. É também complexa, pois envolve a desregulação das múltiplas vias de transdução. Apesar da heterogeneidade

\footnotetext{
${ }^{1}$ www.who.int
} 
observada, a maioria dos tumores apresenta as mesmas características: autosuficiência em sinais de crescimento, insensibilidade para anti-sinais de crescimento, evasão de apoptose, aquisição de um sistema replicativo ilimitado, angiogênese como potencial sustentável, invasão tecidual e metástase (FIG.1) (Pedraza-Fariña, 2006). O câncer é, portanto, um processo multifásico e essas fases refletem alterações genéticas em que células normais são progressivamente transformadas em malignas (Hanahan \& Weinberg, 2000). Estudos de cânceres humanos e modelos animais demonstram que o desenvolvimento do tumor provém de um processo análogo à evolução proposta por Darwin, onde a sucessão das mudanças genéticas sofridas confere algum tipo de vantagem na proliferação, levando a uma progressiva conversão das células humanas normais para células cancerígenas (Nowell, 1976).

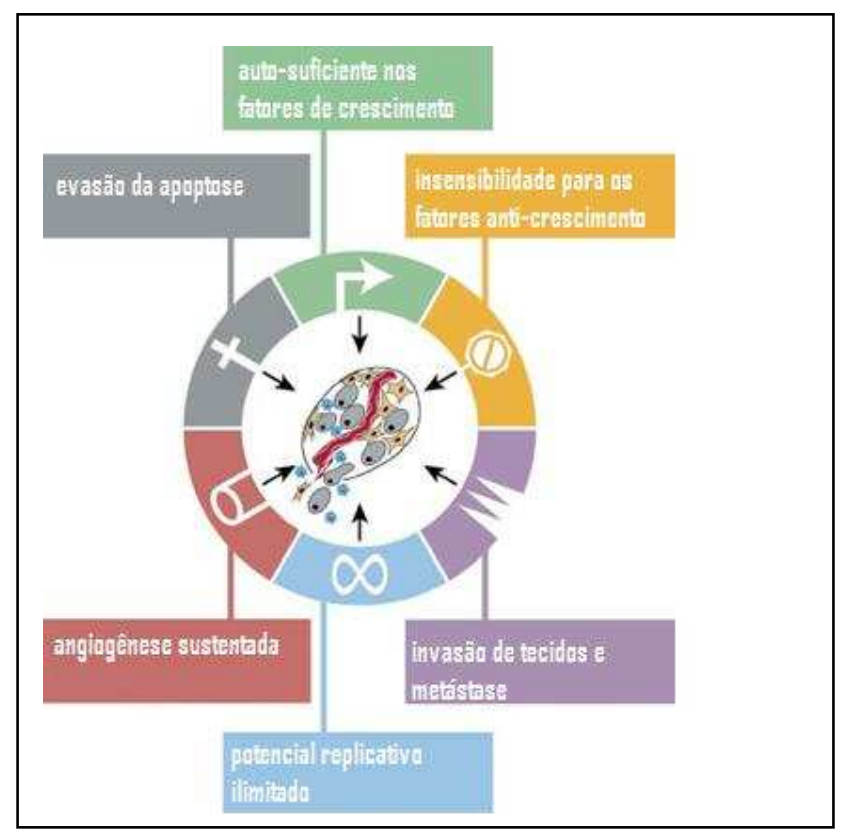

FIGURA 1: Capacidades adquiridas pelo câncer (Hanahan \& Weinberg, 2000).

Hanahan \& Weinberg (2000) acreditam que as células cancerígenas possuem defeitos no circuito regulatório que regem a proliferação e homeostase de células normais. Os autores sugerem que a manifestação dos vários genótipos de células cancerosas são manifestações de alterações na fisiologia da célula que, coletivamente, determinam o crescimento maligno. 
A principal razão para o desenvolvimento do câncer se dá por conta de alterações na seqüência de DNA, que podem ser transmitidas através da linhagem germinativa (cerca de 10\%) e resultar em susceptibilidade ao câncer, ou podem surgir por mutação somática (cerca de 90\%). A mutação somática mais comum envolve translocações cromossômicas e é bastante comum nas leucemias, linfomas e tumores mesenquimais. Mutações em pelo menos 291 genes humanos estão diretamente relacionadas ao desenvolvimento do câncer humano. Cerca de 25.000 genes do genoma humano já foram decodificados, e destes, 1\% está relacionado ao desenvolvimento do câncer (Futreal e cols, 2004).

Segundo Pedraza-Fariña (2006) há uma semelhança no processo celular em todas as células de câncer, independentemente de seu tecido de origem. Isso provavelmente indica que um tumor comum inicia os mecanismos para as patologias complexas encontradas em amostras clínicas do tumor. É possível que haja uma "assinatura genética" em diferentes tipos de cânceres determinada tanto pelo tecido e células de origem, como pelo oncogene ou supressor tumoral que sofreram lesão ou foram mutados.

O modelo utilizado para o desenvolvimento do câncer pode ser reduzido a dois mecanismos independentes: (i) estímulo da proliferação com (ii) um bloqueio simultâneo da morte celular dentro da mesma célula. No entanto, a proliferação e a morte fazem parte do desenvolvimento normal de uma célula, e uma alta taxa proliferativa é necessária em alguns estágios deste desenvolvimento. Dados sugerem que os sinais do ambiente e hábitos da vida cotidiana são cruciais para o estímulo oncogênico dessa proliferação (PedrazaFariña, 2006). Segundo a $\mathrm{OMS}^{3}$, entre os sinais do ambiente e hábitos mais comuns relacionados ao câncer estão: uso de cigarro, exposição ao Sol e presença de vírus.

O que está claro é que o genoma das células tumorais é invariavelmente alterado em vários níveis e que a ativação de oncogenes e inativação dos genes supressores de tumor são etapas críticas para a inicialização e progressão de tumores. Análises moleculares de oncogenes e genes supressores de tumor têm um potencial de fornecer informações úteis no diagnóstico de cânceres, no monitoramento dos efeitos de tratamento

\footnotetext{
${ }^{3}$ www.who.int
} 
anticancerígenos e na confecção de drogas inibidoras do desenvolvimento de alguns tipos de cânceres (Cooper, 2000).

\subsection{Oncogenes}

Os oncogenes conduzem à proliferação anormal celular. Foram originalmente identificados como agentes de transformação em tumores virais, e mais tarde foi encontrada uma versão mutada desses oncogenes que haviam incorporado o genoma viral por recombinação, os proto-oncogenes. Portanto, os oncogenes são obtidos por ativação ou ganho de funções por mutações dos proto-oncogenes (Hunter, 1991). Mutações ou eventos epigenéticos, levam à atividade desregulada ou à expressão aumentada de oncogenes, o que normalmente é encontrado na maioria dos tumores. A ativação de oncogenes está implícita na proliferação celular e as mutações nos mesmos, geralmente, são dominantes (Pedraza-Fariña, 2006).

De acordo com Hunter (1991), experimentos com células primárias de roedores indicaram que a expressão de dois ou mais oncogenes independentes é necessária para a transformação tumorigênica in vitro. Neste contexto há, portanto, o que os pesquisadores chamam de cooperação entre oncogenes. Esta cooperação é definida como uma situação em que um par de oncogenes pode converter uma célula normal em uma linhagem celular tumorigênica, onde um oncogene sozinho não teria tal capacidade. Também a cooperação é usada num sentindo mais amplo abrangendo os casos em que a perda de um gene supressor em conjunto com um ou mais oncogenes contribui para o fenótipo tumorigênico. É por isso, então, que vários eventos são necessários para a carcinogênese; a expressão de oncogenes e a perda de genes supressores cooperam neste processo.

\subsection{Genes supressores de tumor}

Os genes supressores têm a função de inibir a proliferação desenfreada da célula e o desenvolvimento tumoral. Em muitos tumores, estes 
genes são perdidos ou inativos, deixando de expressar suas proteínas que inibiriam os fatores de crescimento celular (Cooper, 2000).

Experimentos sugerem que as células tumorais podem deixar de manifestar um ou mais genes com papéis na regulação negativa do crescimento celular. Esses genes supressores foram localizados em regiões únicas dos cromossomos por meio de técnicas de transferência de cromossomos. A cópia do gene pode ter sido inativada por uma variedade de mecanismos, como por exemplo, um evento genético que resulta em homozigose da região do cromossomo (Hunter, 1991). Estudos levando-se em conta essa probabilidade geraram uma série de genes candidatos a supressores tumorais: pRB (proteína retinoblastoma), p53, DCC (deleção em carcinoma de cólon), e WAGR (Tumor de Wilms, aniridia, anomalia geniturinário e retardo mental). A inativação de genes supressores de tumor ocorre tanto pela perda de função por mutações que inativam a proteína, ou simplesmente por deleção do gene (Hunter, 1991).

As proteínas supressoras tumorais mais estudadas atualmente são a p53 e pRb, cada uma atuando especificamente no ciclo celular. A p53 provoca parada do crescimento das células em G1 o que implica que para as células entrarem na fase S a p53 deve ser "desativada" (FIG. 2) (Bishop, 1991). Pouco se sabe sobre a pRB, embora a expressão do tipo selvagem seja suficiente para reverter e diferenciar certas linhagens de células tumorais humanas (Zhang e cols., 2003). Como a p53, há evidências crescentes de que a pRB age em G1 para impedir a progressão do ciclo celular e a inativação de pRB por fosforilação, permite a entrada na fase S (FIG. 2) (Malumbres \& Barbacid, 2001).

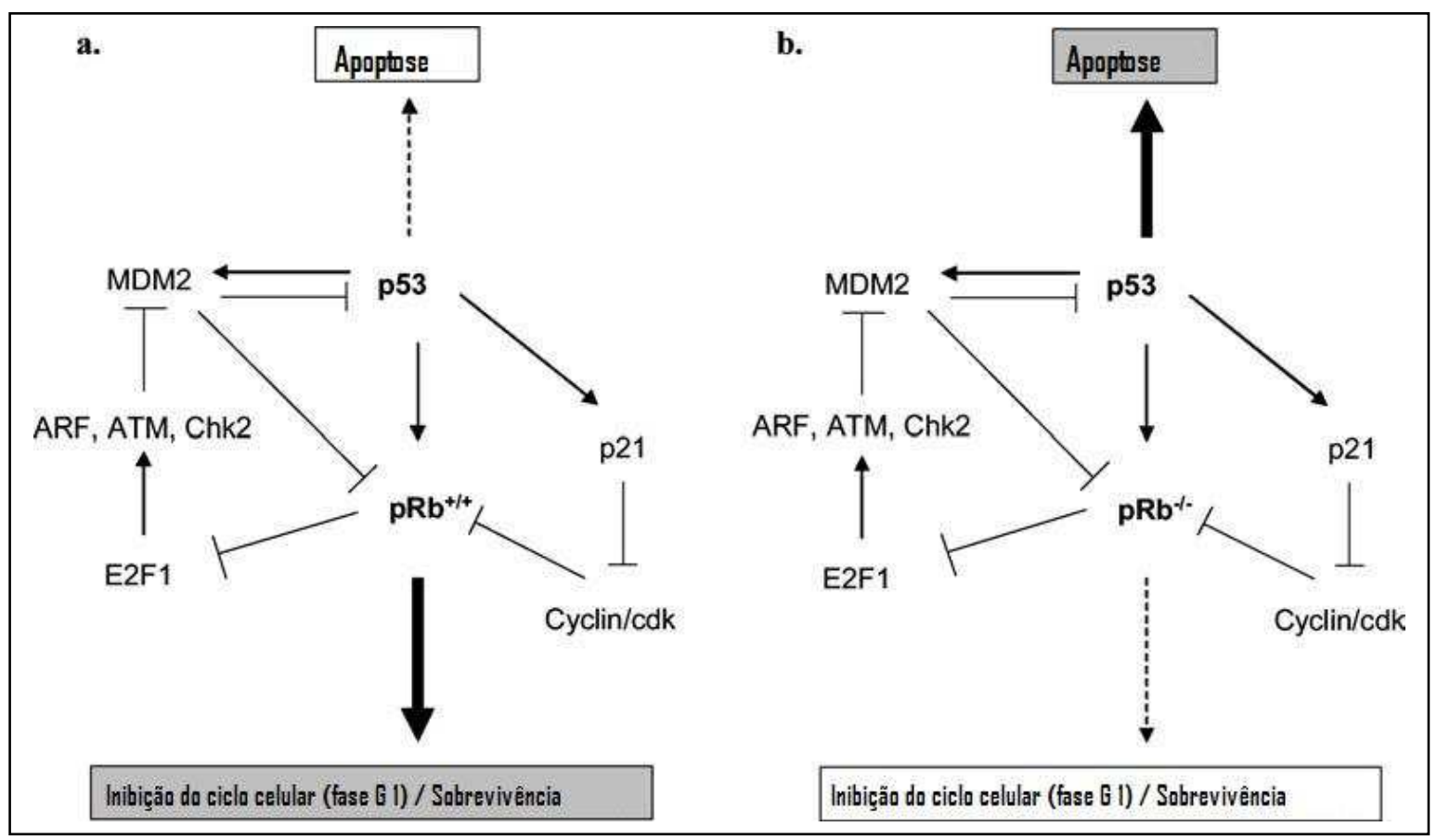


FIGURA 2: Proteínas Supressoras de Tumor (a) p53 e (b) pRb e suas funções no ciclo celular e apoptose (Godefroy e cols., 2006).

Na FIG 2 encontra-se o esquema de atuação algumas das proteínas supressoras de tumor, a p53 e pRB, em a a pRb está ativa, demonstrando o seu papel na condução para parada do ciclo celular em G1. Em b, p53 está ativa e ela prórpia conduz à morte celular programada (apoptose), bem como, ativa outras proteínas supressoras de tumor, como p21 e pRb.

Os genes supressores de tumor normalmente atuam como reguladores negativos das vias que são ativadas por oncogenes. Normalmente estes supressores de crescimento são poderosos o suficiente para interditar o sinal estimulatório fornecido pelos oncogenes e, portanto, há uma forte seleção para inativar estes supressores de tumor (Hunter, 1991).

No intuito de ampliar o conhecimento sobre proteínas supressoras de tumor, foi escolhida como alvo de estudo a Proteína Ribossomal L10 (RP L10), também denominada QM.

\subsection{Proteína QM}

QM é uma proteína ribossomal que participa da ligação das subunidades $60 \mathrm{~S}$ e $40 \mathrm{~S}$ do ribossomo e é indispensável na ligação do RNA mensageiro na tradução (West e cols., 2005). Esta proteína possui massa molecular entre 24 e $26 \mathrm{kDa}$ e ponto isoelétrico (pl) de 10,5. Seu gene é conservado e está presente em diferentes espécies como plantas, animais e fungos o que caracteriza função importante na célula (Farmer e cols., 1996). Loftus e cols. (1997) demonstraram que a proteína QM é periférica e está associada com a membrana, na face citoplasmática da membrana, ao invés de ser uma proteína de membrana integral. Estudos com células de camundongo indicaram que QM é adicionada a subunidade 60S ribossomal, fazendo parte da ligação 40S, no citoplasma e não no núcleo da célula como se pensava inicialmente (Nguyen e cols., 1998). 
O primeiro estudo indicando que a proteína QM tinha ação supressora de tumor foi feito em linhagens celulares de tumor de Wilms (WT-1), um nefroblastoma pediátrico, que possui baixa quantidade de mRNA para esta proteína quando comparada com a concentração deste mRNA em culturas revertidas ao fenótipo normal (Dowdy, 1991). Entretanto, foi com o trabalho de Monteclaro \& Vogt (1993), quando foi estudada uma proteína homóloga a QM, Jif1 (jun-interacting factor 1), demonstrou-se a existência de uma interação de Jif-1 com a proteína Jun. A proteína Jun, por controlar a proliferação celular, atuar no processo de apoptose e na expressão gênica, é uma das proteínas oncogênicas mais estudadas no desenvolvimento de tumores. Esta proteína forma dímeros de Jun: Jun e Jun: Fos, denominados AP-1, que se ligam a seqüências específicas de DNA promovendo a transcrição de fatores de crescimento celular (Angel \& Karin, 1991). A proteína Jif-1/QM liga-se a Jun, impedindo a formação do fator AP-1, desta forma não permitindo a ativação destes fatores de crescimento (Monteclaro \& Vogt, 1993).

A ação de QM não se limita somente à interação com Jun, como fator de supressão de tumor. Estudos feitos por Oh e cols. (2002) mostraram uma interação desta com o a proteína c-Yes, uma tirosina quinase da família Src. As proteínas quinases são proto-oncogenes que participam de funções na morfologia, proliferação e sobrevivência da célula (Roskoski, 2004). Esta interação QM: c-Yes reduz a atividade quinase in vitro de c-Yes em $70 \%$, em linhagens de células Hela, HT29, Kato III, SNU16 e SW480.

A proteína QM recentemente foi relacionada com outros cânceres humanos. Seu mRNA foi encontrado em menor quantidade em células tumorais de estômago, em câncer de ovário e adenocarcinoma de próstata (Meireles, 2003; Shen e cols., 2006; Altinok e cols., 2006).

O trabalho de Massad-Costa e cols. (2007), estudando pacientes com falência ovariana prematura, detectou que nessas pacientes, o gene para proteína QM encontrava-se mutado em pelo menos cinco pontos e em quatro deles, as alterações dos nucleotídeos determinou mudanças nos aminoácidos o que se mostrou compatível com um aumento da estabilidade da proteína levando à ativação descontrolada da mesma em células de ovário com um conseqüente aumento da ocorrência de apoptose. 
Com estas funções extra-ribossomais e por possuir características bioquímicas adequadas para expressão em sistema bacteriano, como não ser glicosilada, ser hidrofílica e básica (Farmer e cols., 1996), esta proteína poderia ser expressa neste sistema em quantidades adequadas para estudos mais detalhados de sua estrutura.

\subsection{Sistema bacteriano de expressão}

A expressão de proteínas recombinantes em microrganismos transformados tem se mostrado uma técnica fundamental na biologia molecular moderna (Qoronflech e cols., 2007). A produção de proteínas recombinantes, principalmente as de eucariotos, vem sendo feita desde a década de 70. Em um primeiro momento, as proteínas eram extraídas diretamente de animais, o que não se mostrou uma alternativa adequada, pois além da dificuldade de obtenção em quantidades comerciais, havia o problema da contaminação com vírus e questões éticas relacionadas. As proteínas extraídas serviam como substitutos de proteínas ou hormônios endógenos, como o hormônio do crescimento ou insulina, e substâncias que bloqueiam o desenvolvimento de cânceres, como o interferon, além de insumos para a agricultura e pecuária.

O aumento da demanda incentivou o desenvolvimento das técnicas de manipulação e expressão. Estas se tornaram mais eficientes e hoje temos uma série de sistemas de expressão in vivo e in vitro com diversas finalidades.

As proteínas recombinantes podem ser obtidas em diferentes hospedeiros como, bactérias, leveduras, células de mamíferos sendo que, a bactéria é o meio de expressão de proteínas heterólogas mais utilizado, principalmente a bactéria Escherichia coli. É um organismo bastante conhecido geneticamente, seu cultivo é rápido e pode produzir altas quantidades de proteína recombinante a baixo custo, porém é um sistema limitado, pois não há modificações pós-traducionais (Makrides, 1996).

No sistema bacteriano, a proteína recombinante expressa pode ser enviada para três regiões diferentes:

- Meio extracelular, onde a proteína recombinante é enviada para o meio de cultura. A expressão pode resultar em altas quantidades de 
proteína e esta ter a conformação nativa. Porém, com o cultivo, o meio passa a ter proteases que degradam as proteínas produzidas, além de diluí-las (Sorensen e cols., 2005).

- Periplasma bacteriano, região localizada entre a membrana celular e a parede bacteriana. Neste ambiente o meio é oxidativo e possui enzimas que possibilitam a conformação natural da proteína, porém em baixas concentrações (FIG. 3) (Makrides, 1996).

- Citoplasma bacteriano, onde a proteína é expressa em grandes quantidades, porém de forma agregada (corpos de inclusão). Estes agregados podem conter $90 \%$ da proteína de interesse, mas para a obtenção da proteína solúvel é necessário o uso de reagentes desagregadores (guanidina ou uréia), ou técnicas com alta pressão hidrostática ou temperaturas de cultivo baixas (FIG. 3) (Clark, 2001). 


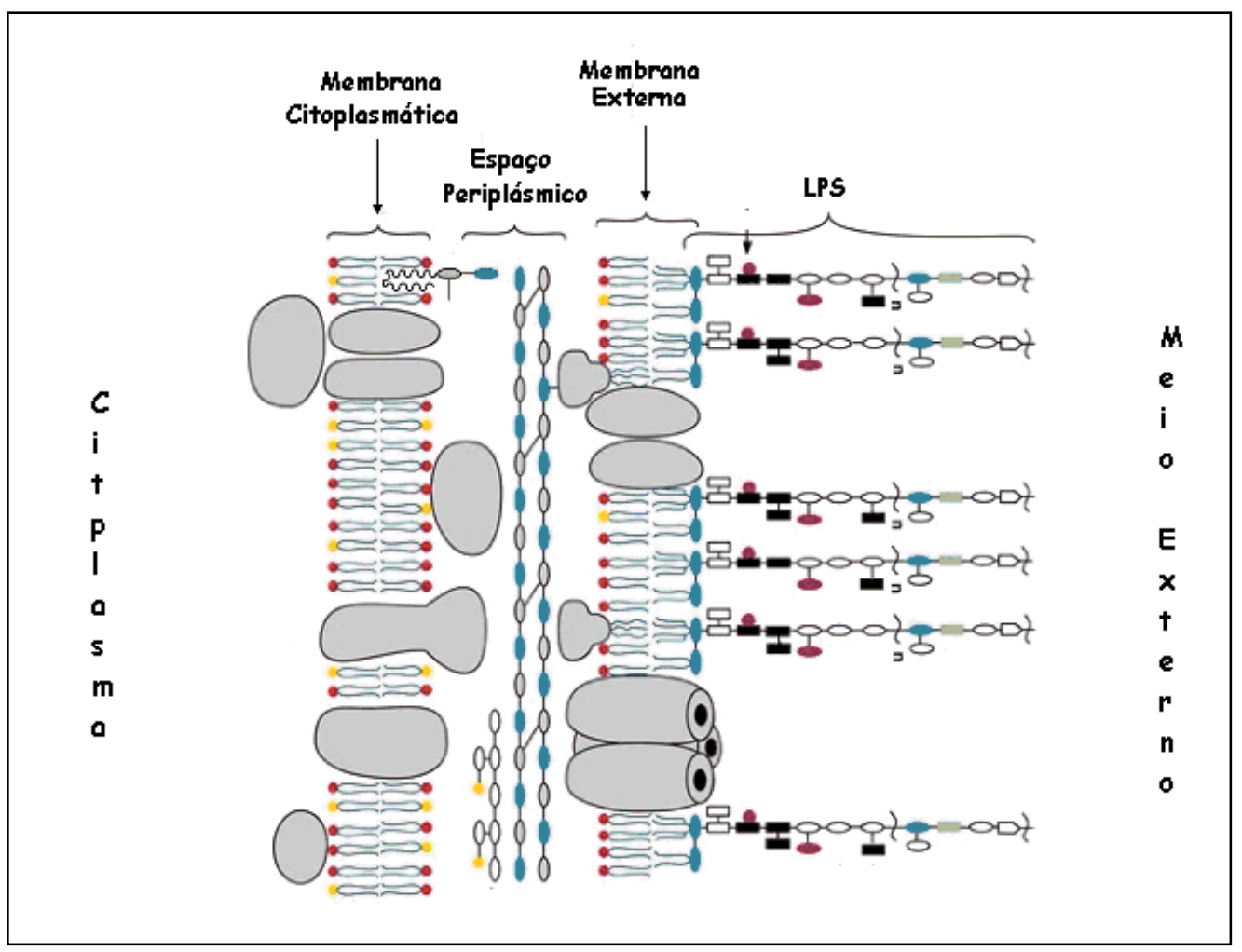

FIGURA 3: Esquema da parede bacteriana de E. coli. (modificado de vários autores).

Nos estudos estruturais e de bioatividade, há a necessidade de se obter grandes quantidades de proteínas solúveis por isso é muito importante a escolha do tipo sistema em que se pretende expressar a proteína de estudo e qual a estratégia a utilizar.

De posse da proteína solúvel é possível realizar uma série de análises conformacionais e de estabilidade por meio de técnicas como Fluorescência e Dicroísmo Circular, que geram um conjunto de elementos estruturais que definem a estrutura da proteína, o que é fundamental para o conhecimento sobre sua função. 


\section{OBJETIVOS}

O presente trabalho teve com objetivos:

- Clonagem do gene da proteína humana QM em vetor de expressão periplásmica

- Expressão da proteína no periplasma e citoplasma da bactéria Escherichia coli e, comparação dos dois tipos de expressão em termos de rendimento protéico

- Purificação da proteína QM humana recombinante;

- Caracterização da estrutura secundária com análise por Dicroísmo Circular;

- Caracterização da estrutura terciária com análise por Fluorescência;

- Estudo da estabilidade protéica por Dicroísmo Circular. 


\section{METODOLOGIA}

\subsection{Materiais}

\subsubsection{Equipamentos e acessórios principais}

- Agitador rotatório de tubos (Tayo Rotator).

- Aparelho Mili-Q-plus, purificador de água (Millipore).

- Autoclave, modelo SS-245E (Tomy).

- Banho-maria, modelo 100, (Fanem).

- Banho-maria, modelo Type 16500 Dri-Bath (Thermolyne).

- Balança analítica, modelo AW 220 (Shimadzu).

- Balança de precisão, modelo P1200 (Mettler).

- Centrífuga refrigerada automática, modelo 5810R (Eppendorf).

- Centrífuga refrigerada automática, modelo (Sorvall).

- Colunas (exclusão molecular, troca catiônica, his-tag, hidrofobicidade).

- Espectrofotômetro (Beckman).

- Espectropolarímetro Jasco J-810

- Estufa bacteriológica (QUIMIS).

- Filmes radiográficos (Kodak).

- Fluorímetro AB2 Luminescence Spectrometer

- Fluxo laminar modelo 2256 (TROX).

- Freezer -80ㄷ, modelo 939 (Forma Scientific, Inc).

- Image Master VDS (Amershan pharmacia).

- Incubadora refrigerada com agitação, modelo TE421 (TECNAL).

- Integrated Speed Vack System, Farmingdale, NY (Savant Instruments INC). 
- Termociclador para a técnica de PCR 240024 poços (Perkin Elmer Gene Amplification).

- Sistema de eletroforese vertical, modelo SE250, Hoefer (Pharmacia Biotech).

- Sistema semi-seco de eletrotransferência (BioRad).

- Sonicador, Danbury Connecticut U.S. ${ }^{\text {a }}$ (Sonics \& Materials Inc).

\subsubsection{Reagentes}

- Agarose, Grau Biologia Molecular (BioRad).

- Antibióticos: Canamicina (Invitrogen).

- Anticorpo secundário conjugado a peroxidase de cavalo (Armeshan Pharmacia Biotech).

- Anticorpo policlonal.

- Kit de purificação de DNA plasmidial, WizardPlus S. V. (Promega).

- Kit de purificação do DNA em gel de agarose, QIAquick Gel Extraction (Quiagen).

- Kit de quimioluminescência para revelação de Western blotting ECL, (Armesham Pharmacia Biotech).

- Leite em pó desnatado e liofilizado (Molico).

- Vetores de clonagem pET26b+ (Novagen), p3SN8 e p1813.

\subsubsection{Meios de cultura}

Todos os meios de cultura foram preparados com água deionizada MilliQ (Millipore).

- LB - Triptona $10 \mathrm{~g} / \mathrm{L}$, extrato de levedura $5 \mathrm{~g} / \mathrm{L}$, cloreto de sódio 10 $\mathrm{g} / \mathrm{L}$ (o pH deve ser ajustado para 7,0 com $\mathrm{NaOH} 0,1 \mathrm{~N}$ ) e o meio deve ser esterilizados por autoclave.

- LB-ágar - $15 \mathrm{~g}$ de select-agar para 1L de meio de cultura líquido, deve ser esterilizado por autoclave e quando estiver em temperatura 
ambiente, distribuí-lo em placas de $50 \mathrm{~cm}^{2}$ em superfície plana nivelada e esperar solidificar. Estocar a $4^{\circ} \mathrm{C}$ por a té 1 mês.

- SOC - Triptona $20 \mathrm{~g} / \mathrm{L}$, extrato de levedura $5 \mathrm{~g} / \mathrm{L}$, cloreto de sódio 0,5 g/L, 2,5 mM de $\mathrm{KCl}$ (ajustar o pH para 7,0 com NaOH $5 \mathrm{~N}$ ), o meio deve ser esterilizado em autoclave, antes de usar acrescentar $10 \mathrm{mM}$ de $\mathrm{MgCl}_{2}$ e $20 \mathrm{mM}$ de glicose.

\subsubsection{Soluções}

Todas as soluções foram preparadas em água deionizada Milli-Q (Millipore).

- PBS - Cloreto de potássio 2,7 mM, cloreto de sódio $137 \mathrm{mM}$, fosfato dibásico de sódio $8,1 \mathrm{mM}$, fosfato monobásico de potássio $1,5 \mathrm{mM}$ $\mathrm{pH} 7,4$.

- Solução de acrilamida $30 \%$ - acrilamida $29 \%, \quad N, \quad N$ metilenobisacrilamida $1 \%$ em água deionizada.

- Solução de azul de Comassie - ácido acético glacial 10\%, azul de Comassie R250 0,25\%, etanol 45\%.

- Solução descorante - ácido acético glacial 10\%, metanol 30\%.

- Tampão TAE - EDTA $1 \mathrm{mM}$, TRIS $40 \mathrm{mM}$, ácido acético $20 \mathrm{mM}$ pH 8,5 .

- Tampão de amostra 10x para o gel de agarose - azul de bromofenol 0,25\%, Ficol (tipo 400) 15\%, xileno cianol FF 0,25\% em água deionizada.

- Tampão de amostra 5x para SDS-PAGE - azul de bromofenol 0,1\%, glicerol $10 \%, \beta$-mercaptoetanol $100 \mathrm{mM}$, SDS $2 \%$, tris- $\mathrm{HCl} 50 \mathrm{mM}$, $\mathrm{pH} 6,8$.

- Tampão de corrida para SDS-PAGE - glicina $192 \mathrm{mM}$, SDS 0,1\%, tris $25 \mathrm{mM}$.

- Tampão de transferência - glicina $192 \mathrm{mM}$, metanol 20\%, SDS $0,01 \%$, tris $25 \mathrm{mM}, \mathrm{pH} 8,3$. 
- Solução RF I- KCl $10 \mathrm{mM}, \mathrm{MnCl}_{4} 50 \mathrm{mM}$, acetato de potássio 30 $\mathrm{mM}, \mathrm{CaCl}_{2} 10 \mathrm{mM}$, glicerol 15\%, pH 5,8, esterilizar em filtro de 0,22 $\mu \mathrm{m}$.

- Solução RF II - KCl 10 mM, $\mathrm{CaCl}_{2} 75$ mM, MgCl 20 mM, Na-MOPS $10 \mathrm{mM}$, glicerol 15\%, pH 5,8, esterilizar em filtro 0,22 $\mu \mathrm{m}$.

- Solução alcalina I: $50 \mathrm{mM}$ de Glicose, $25 \mathrm{mM}$ de tris-HCl $(\mathrm{pH} 8,0)$ e $10 \mathrm{mM}$ de EDTA (pH 8,0), Estocar a 4 $\mathrm{C}$.

- Solução alcalina II: $0,2 \mathrm{~N}$ de $\mathrm{NaOH}$ e $1 \%$ de SDS. Estocada em temperatura ambiente.

- Solução alcalina III: $5 \mathrm{M}$ de acetato de potássio, $3 \mathrm{M}$ de ácido acético glacial, completar com água destilada para $50 \mathrm{~mL}$. Estocar a $4^{\circ} \mathrm{C}$ e transferir para gelo na hora em que for usar.

\subsection{Metodologias}

\subsubsection{Vetor e cepa}

\subsubsection{Vetor de expressão bacteriano}

O primeiro vetor de expressão utilizado foi o $\mathrm{pET} 26 \mathrm{~b}+$ (Novagen) possui uma seqüência codificante denominada pelB, que possibilita o direcionamento da proteína recombinante para o espaço periplásmico. Este vetor foi clivado com as enzimas Nco I e Bam HI para poder incorporar o inserto, e em seguida foi defosforilado para não haver a possibilidade de união das duas extremidades (FIG. 4). O cDNA para a proteína QM, que foi amplificado a partir de RNA mensageiro (mRNA) de tecido mamário, foi retirado do plasmídeo pTOPO101_QM com as mesmas enzimas utilizadas para a digestão do vetor. $O$ segundo vetor de expressão utilizado foi o p3SN8 (FIG. 4) que também direciona a proteína expressa para o espaço periplásmico da cepa e, finalmente, foi utilizado o vetor de expressão p1813, muito semelhante ao p3SN8. O vetor de expressão p1813, porém, não direciona a proteína para o periplasma: a proteína é produzida e permanece no citoplasma bacteriano, mas a quantidade produzida é, de modo geral, superior aos dois primeiros vetores. 


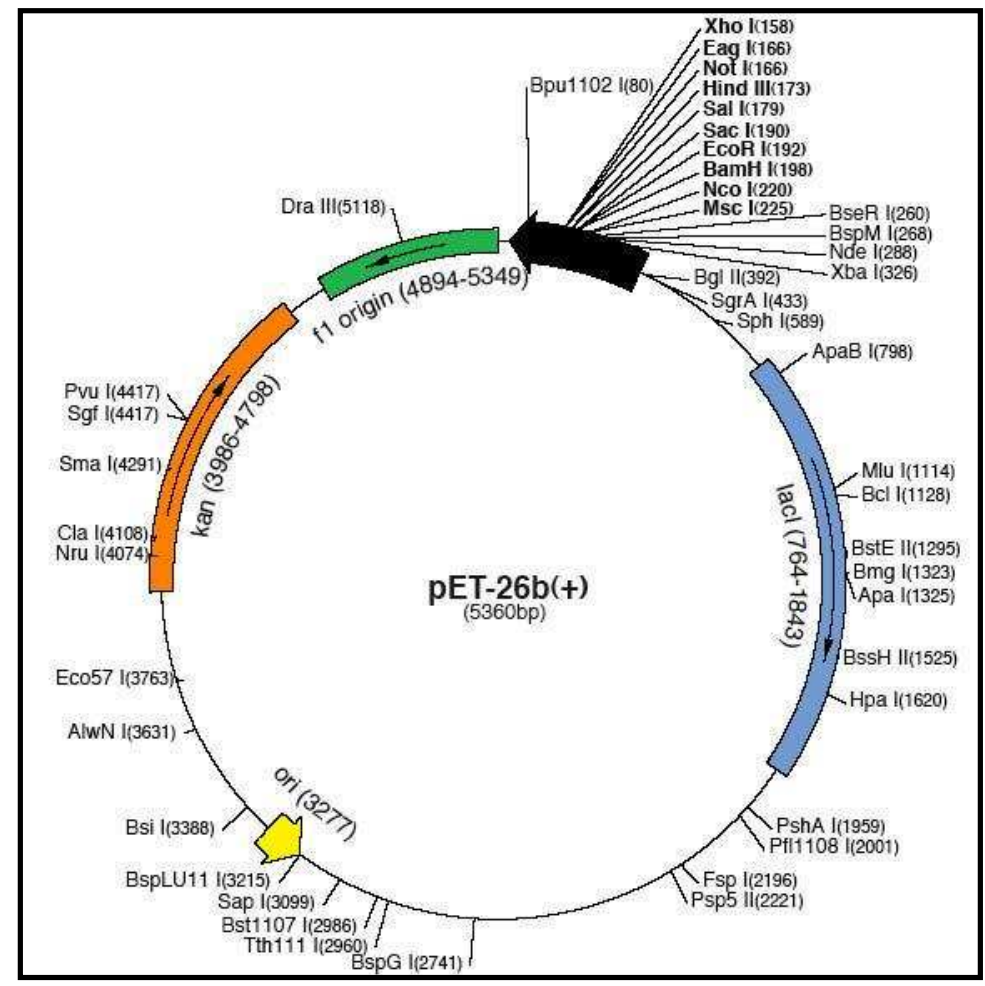

a

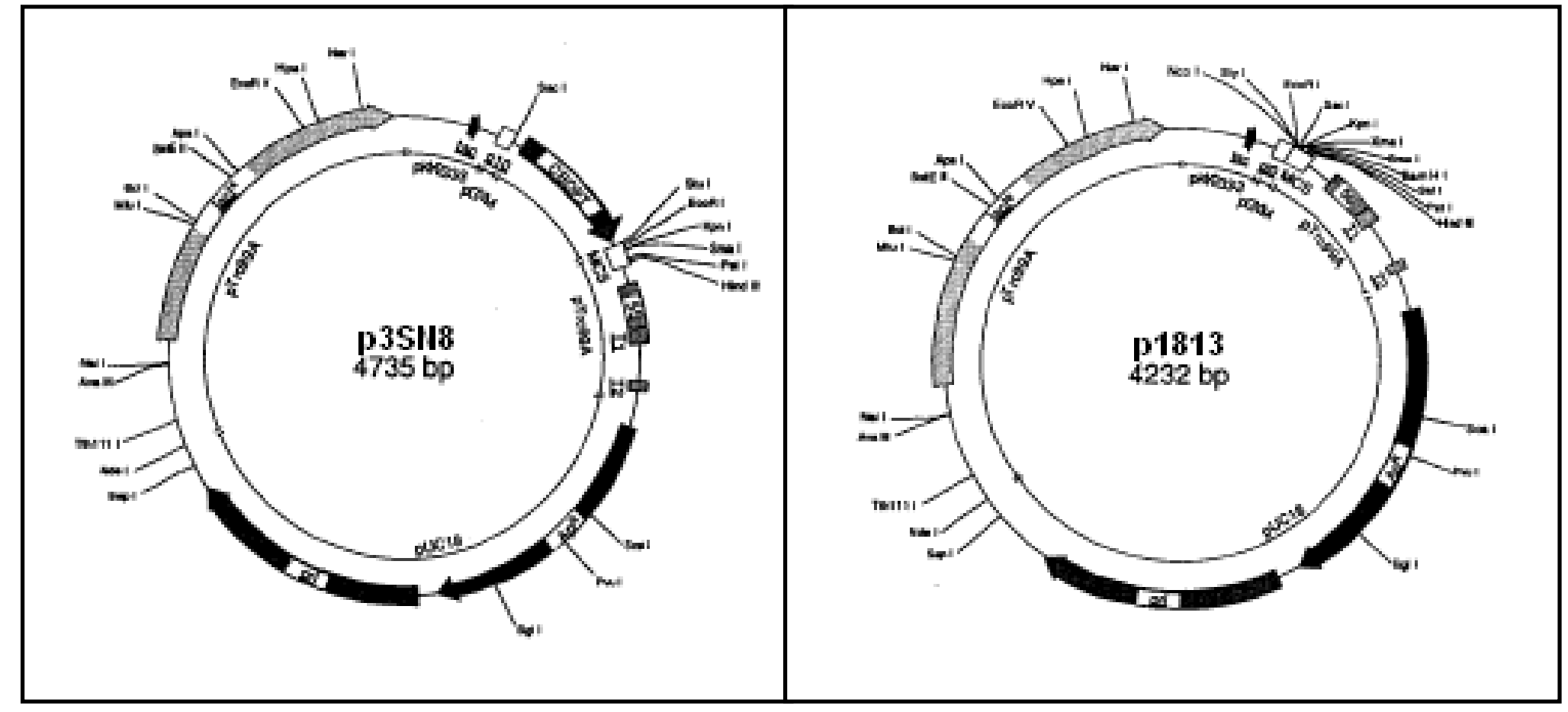

b

C

FIGURA 4: Vetores de expressão periplásmica (a) pET26b (Novagen), (b) p3SN8 e citolplásmica (c) p1813 com seus respectivos sítios de clonagem. 


\subsubsection{Cepa de E.coli utilizada}

A cepa de Escherichia coli BL21(DE3) foi utilizada na expressão da proteína QM com o vetor pET26_QM, pois é a mais adequada na ativação de proteínas recombinantes por IPTG (isopropil- $\beta-D-$ tiogalactopyranoside). Utilizada para ativação indireta de promotor T7 no plasmídeo pET26b.

A cepa BL 21(DE3) possui as seguintes características genéticas: $\operatorname{Star}^{\mathrm{TM}}$ (DE3) $\mathrm{F}^{-}$ampT hsdS $\mathrm{B}_{\mathrm{B}}\left(\mathrm{r}_{\mathrm{B}}^{-} \mathrm{m}_{\mathrm{B}}^{-}\right)$gal dcm rne131 (DH3).

A cepa de E. coli HB 2151 foi utilizada com os vetores p3SN8 e p1813 e possui as seguintes características: K12-ara $\Delta$ lac-pro thi ( $F^{\prime}$ proAB lacl $\left.{ }^{q} \Delta \mathrm{M} 15\right)$ (Luck e cols., 1989).

\subsubsection{Amplificação dos plasmídeos}

\subsubsection{Preparação dos plasmídeos}

A preparação dos plasmídeos foi realizada por lise alcalina seguida por uma etapa de purificação e precipitação do DNA. A lise alcalina é um dos procedimentos mais usados para a extração rápida de plasmídeos bacterianos.

Primeiramente foi inoculado, em $2 \mathrm{~mL}$ de meio de cultura LB contendo antibiótico apropriado ao crescimento, uma colônia de bactéria transformada com o plasmídeo de interesse.

Este inóculo foi incubado por 16 horas à $37^{\circ} \mathrm{C}$ com a gitação em torno de 200 RPM. $O$ volume de $1,5 \mathrm{~mL}$ desta cultura foi centrifugado por 1 minuto a $4^{\circ} \mathrm{C}$. Retirou-se bem o sobrenadante. O sobrenadante contém componentes da parede bacteriana que inibem posterior digestão enzimática.

O precipitado foi ressuspendido em STE num volume de $0,25 \times 0$ volume original de cultura e centrifugado por 1 minuto a $4^{\circ} \mathrm{C}$. O sobrenadante foi retirado.

Após esse processo inicial foi realizada a lise alcalina.

O precipitado foi ressuspendido em $100 \mu \mathrm{L}$ de solução alcalina I gelada com agitação vigorosa. Adicionou-se $200 \mu \mathrm{L}$ de solução alcalina II recém 
preparada. O tubo foi invertido por cinco vezes e colocado em banho de gelo por 2 minutos. A solução II por conter SDS e $\mathrm{NaOH}$ rompe a parede bacteriana liberando os componentes celulares.

Por fim, adicionaram-se $150 \mu \mathrm{L}$ de solução alcalina III gelada (esta solução contém íons $\mathrm{H}+$ que se ligam ao $\mathrm{PO}_{4}{ }^{-}$da dupla hélice de DNA tornando-a sem carga, possibilitando a precipitação deste). O tubo foi invertido por cinco vezes e colocado em gelo por 3 minutos. Após este período a amostra foi centrifugada por 10 minutos a $4^{\circ} \mathrm{C}$ a 14.000 RPM e o sobrenadante foi transferido para um tubo novo.

\subsubsection{Remoção de proteínas e RNA (extração do DNA com limpeza por fenol)}

Nas soluções de DNA em que foi necessária a retirada de proteínas e RNA, foi adicionado um volume igual ao da amostra de uma mistura composta por um volume de $400 \mu \mathrm{L}$ de fenol/clorofórmio, na proporção 1:1; álcool isoamílico. Após agitação por um minuto e centrifugação a 14.000 RPM por 5 minutos a $4^{\circ} \mathrm{C}$, o sobrenadante foi retirado e transferido para um novo tubo, onde foi adicionado um volume igual ao anterior de clorofórmio. A mistura foi homogeneizada e centrifugada nas mesmas condições anteriores e o sobrenadante foi passado para um tubo limpo.

\subsubsection{Precipitação do DNA}

Neste DNA "limpo de impurezas", após a passagem pelo fenol/clorofórmio, foi acrescentado um volume correspondente a $1 \%$ do volume da amostra de DNA, de acetato de sódio $(0,3 \mathrm{M})$ e dois volumes da amostra, de etanol. Após 15 minutos de incubação em gelo a amostra foi centrifugada a 14.000 RPM por 15 minutos a $4^{\circ} \mathrm{C}$. O DNA precipitado foi lavado com mesmo volume de etanol $70 \%$, centrifugado nas mesmas condições descritas 
anteriormente e seco em centrífuga speedvac. Este foi ressuspendido em $50 \mu \mathrm{L}$ água estéril e guardado a $-20^{\circ} \mathrm{C}$.

\subsubsection{Eletroforese em gel de agarose}

Os tamanhos do DNA plasmidial e de fragmentos de DNA foram analisados por migração em gel de agarose a 1\%. Para a preparação de géis, a agarose foi adicionada ao tampão TAE e a mistura aquecida em forno microondas até formar uma solução homogênea. A solução foi resfriada até aproximadamente $60^{\circ} \mathrm{C}$ e foi adicionada ao suporte para a solidificaç ão. Depois de solidificado, o gel foi imerso em solução de brometo de etídio na concentração de $1 \mu \mathrm{g} / \mathrm{mL}$, para permitir a visualização das bandas de DNA sob luz ultravioleta. O tampão de corrida utilizado foi TAE e a separação eletroforética foi feita sob tensão de $70 \mathrm{~V}$, por cerca de 1 hora. $O$ tamanho do DNA foi determinado por comparação de sua mobilidade com a dos marcadores de massa molecular, introduzido na primeira canaleta do gel no momento da corrida.

\subsubsection{Separação e purificação de DNA}

Após as clivagens com as enzimas, o cDNA e o vetor, foram submetidos a uma eletroforese em gel de agarose 1\%, corados com brometo de etídio e visualizados com luz UV. Após a separação eletroforética dos fragmentos de DNA, a banda correspondente ao fragmento de interesse foi cortada do gel com um estilete estéril e purificada com o uso do "Kit QIA quick" (Quiagen).

\subsubsection{PCR para amplificação do gene da proteína QM}

Primers flanqueadores foram especialmente desenhados com base em análises do genoma para a amplificação da seqüência gênica de interesse no vetor de expressão periplásmica. Foram incluídos sítios de restrição escolhidos para permitir a ligação do gene ao plasmídeo de expressão. 
- Primer sense: CTA GCT AGC ATG GGC CGC CCC GCC, que contém o sítio de restrição para a enzima Nhel na extremidade 5' do DNA.

- Pimer anti-sense: C GGG ATC CTC ATG AGT GCA GGG CCC GCC, que contém o sítio de restrição para a enzima BamHI na extremidade 3' do DNA.

O cDNA do gene de QM foi amplificado por reação de polimerização em cadeia (PCR) usando DNA genômico como molde. Etapas da amplificação: 50 $\mu \mathrm{L}$ de reação, DNA molde desnaturado a $94^{\circ} \mathrm{C}$ por 30 s egundos, hibridação com os primers $5^{\circ} \mathrm{C}$ por 30 segundos, extensão com DNA-polimerase (Taq-

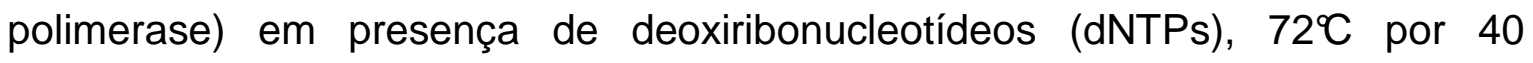
segundos. Foram realizados 30 ciclos em termociclador (Perkin-Elmer).

Os produtos de PCR foram submetidos a eletroforese em gel de agarose e purificados, após essas etapas deu-se a reação de ligação.

\subsubsection{Reação de ligação de DNA}

As ligações dos fragmentos de DNA de interesse aos plasmídeos linearizados foram feitas em $10 \mu \mathrm{L}$ de reação contendo a mistura do inserto com $50 \mathrm{ng}$ de vetor linearizado, numa proporção de $80 \mathrm{ng}$ de inserto para $100 \mathrm{ng}$ de vetor. Na reação de ligação de vetor com inserto foi utilizada uma unidade de T4 DNA ligase para $50 \mathrm{ng}$ de DNA, e $1 \mu \mathrm{L}$ de tampão de ligação (fornecido pelo fabricante). As reações foram incubadas por 16 horas a $1^{\circ} \mathrm{C}$.

\subsubsection{Preparo de bactérias competentes}

Competência de E.coli por $\mathrm{CaCl}_{2}$ : as bactérias foram estriadas em placa LB-ágar, incubadas por 16 horas a $37^{\circ} \mathrm{C}$. Uma c olônia isolada foi inoculada em $2 \mathrm{~mL}$ de meio LB e este mantido por 16 horas a $3^{\circ} \mathrm{C}$. O inóculo foi transferido para $100 \mathrm{~mL}$ de meio LB e a suspensão incubada por 2-3 horas a $37^{\circ} \mathrm{C}$ sob agitação. Ao atingir densidade ótica (OD $600 \mathrm{~nm}$ ) igual a 0,6 lido em espectrofotômetro, o cultivo foi transferido para gelo para estacionar a divisão 
celular. $\mathrm{O}$ inóculo foi dividido em 2 tubos $(50 \mathrm{~mL}$ ) aos quais foram adicionados 2 $\mathrm{mL}$ de $\mathrm{MgCl}_{2} 1 \mathrm{M}$, e centrifugados a $14.000 \mathrm{RPM}$ por 10 minutos a ${ }^{\mathrm{C}} \mathrm{C}$. Os precipitados foram ressuspendidos em $5 \mathrm{~mL}$ RF I, centrifugados por 15 minutos a 10.000 RPM a $4^{\circ} \mathrm{C}$, o sobrenadante foi descartado e a operação foi repetida. Então o precipitado foi ressuspendido em $1 \mathrm{~mL}$ de solução RF II, e distribuído em alíquotas de $50 \mu \mathrm{L}$ em microtubos de $1,5 \mathrm{~mL}$, os quais foram imediatamente congelados e estocados a $-80^{\circ} \mathrm{C}$.

\subsubsection{Transformação de bactérias E.coli}

Alíquotas de células quimicamente competentes $(50 \mu \mathrm{L})$ foram descongeladas em gelo, e a elas adicionados 1 a $5 \mu \mathrm{L}$ de solução de reação de ligação. As misturas foram mantidas em gelo por 30 minutos e então submetidas a choque térmico a $42^{\circ} \mathrm{C}$ por 2 minutos, voltando ao banho de gelo por mais 5 minutos. Em seguida foram adicionados $300 \mu \mathrm{L}$ de meio de cultura SOC às suspensões de células e estas foram mantidas por 90 minutos a $37^{\circ} \mathrm{C}$ sob agitação. Após esse período, as suspensões foram plaqueadas em meio LB-ágar contendo o antibiótico apropriado.

\subsubsection{Expressão da proteína recombinante}

\subsubsection{Crescimento do inóculo}

Para expressão de proteínas recombinantes, cepas bacterianas, BL21(DE3), transformadas com o plasmídeo de interesse foram cultivadas em 5 $\mathrm{mL}$ de meio de cultura LB com canamicina $(50 \mu \mathrm{g} / \mathrm{mL})$, mantidos sob agitação em torno de 200 RPM à temperatura de $37^{\circ} \mathrm{C}$ por 16 horas, ao final deste período a cultura foi diluída na proporção 1:20 em meio LB com canamicina e mantida nas mesmas condições de crescimento citadas acima, até a cultura atingir uma densidade óptica entre 0,5 e 0,8 com comprimento de onda de $600 \mathrm{~nm}$. As culturas foram separadas em frações para gerar controles, não induzido e induzidos. 


\subsubsection{Ativação com adição de IPTG}

Quando a absorbância desejada foi atingida, foi adicionado IPTG em uma concentração final de $0,5 \mathrm{mM}$, este reagente promove a expressão da proteína de interesse. A ativação das bactérias contendo os plasmídeos recombinantes pET26_QM e p3SN8_QM foi feita por 16 horas a $37^{\circ} \mathrm{C}$, com coletas de amostras nos tempos de 3, 5, 7 e 15 horas, as quais foram analisadas em SDS-PAGE para se determinar o tempo em que a proteína é expressa em maior concentração pela bactéria. Como controle negativo foi utilizado o mesmo clone, crescido pelo mesmo tempo de 16 horas, sem ativação por IPTG. Para o plasmídeo recombinante p1813_QM foi feito uma seleção das diferentes temperaturas de ativação, $1^{\circ} \mathrm{C}, 2^{\circ} \mathrm{C}, 30^{\circ} \mathrm{C}, 3^{\circ} \mathrm{C}$ e $4^{\circ} \mathrm{C}$ (Vera e cols., 2007), para verificar se havia diferença na quantidade de proteína solúvel produzida.

\subsubsection{Extração da proteína heteróloga QM por choque osmótico}

Para extração da proteína do espaço periplásmico foram testados quatro protocolos de choque osmótico diferentes. Todos resultando numa mudança da permeabilidade da superfície estrutural da bactéria.

No primeiro protocolo testado, foi seguido o modelo de choque osmótico descrito por Koshland \& Botstein (1980). Foram utilizados $40 \mathrm{~mL}$ de uma cultura com densidade óptica igual a 4 lida em $600 \mathrm{~nm}$, a cultura foi centrifugada a 3.500 RPM por 5 minutos a $4^{\circ} \mathrm{C}$. Os pellets gerados foram ressuspendidos em 5,0 $\mathrm{mL}$ ou $2,5 \mathrm{~mL}$ de solução $10 \mathrm{mM}$ tris- $\mathrm{HCl}, \mathrm{pH} 8,0$, contendo $20 \%$ de sacarose $(\mathrm{w} / \mathrm{v})$ gelada e adicionados $20 \mu \mathrm{l}$ de EDTA $0,5 \mathrm{M}, \mathrm{pH} 8,0$, incubados no gelo por 10 minutos sob agitação moderada. As células foram centrifugadas e o pellet foi ressuspendido em $5,0 \mathrm{~mL}$ ou $2,5 \mathrm{~mL}$ de solução de $0,5 \mathrm{mM} \mathrm{MgCl}$. Essa suspensão foi mantida em temperatura ambiente por 10 minutos com agitação e centrifugada novamente por 5 minutos. O sobrenadante foi reservado para análises.

O segundo protocolo testado foi modificado de Matsushita e cols. (1981), nele $50 \mathrm{~mL}$ de cultura ativada foram centrifugadas e ressuspendidas em 5 
$\mathrm{mL}$ de solução de tris-HCl 20 mM 1 mM EDTA pH 7,5 + sacarose $20 \%$ + 4,8 $\mu \mathrm{g}$ de lisozima. A suspensão foi agitada vigorosamente e mantida em agitação moderada por 10 minutos a $30^{\circ} \mathrm{C}$. Essa amostra foi novamente centrifugada a 14.000 RPM por 10 minutos e o sobrenadante foi reservado.

A enzima lisozima é muito utilizada em procedimentos de choque osmótico, a sua atividade catalítica é a hidrólise da ligação glicosídica que une os resíduos de açúcares aminados componentes do peptidioglicano da parede celular de bactérias (Lopes e cols., 2004).

O terceiro protocolo foi realizado de acordo com Soares e cols. (2003), onde $20 \mathrm{~mL}$ de cultura ativada foram centrifugados por 5 minutos a 5.000 RPM. $O$ pellet foi ressuspendido em uma solução gelada de $10 \mathrm{mM}$ tris- $\mathrm{HCl} \mathrm{pH} 8,0$ contendo $20 \%$ de sacarose (w/v) e EDTA correspondendo a:

Vol. Sacarose $=\underline{A_{600}} \underline{X \text { Vol. Meio }}$ 100

Vol. EDTA = Vol. Sacarose

30

Esta solução foi incubada em gelo por 10 minutos sob agitação moderada. As células foram centrifugadas e o pellet ressuspendido em tris- $\mathrm{HCl} 20$ $\mathrm{mM}$ pH 7,5 (mesmo volume usado para sacarose). Essa suspensão foi mantida em temperatura ambiente por 10 minutos com agitação e centrifugada novamente por 5 minutos. O sobrenadante foi reservado para análises.

Foi analisada, também, a eficiência de um choque feito em microescala descrito por Borjaliloo e cols. (2003). Neste choque utilizou-se 1,5 mL de cultura ativada com a Ab600 igual a um. Esta cultura foi centrifugada a 14.000 RPM por 5 minutos a $4^{\circ} \mathrm{C}$ e ressuspendida em $15 \mu \mathrm{L}$ de tris-HCl 0,2 M, EDTA 0,5 $\mathrm{M}$, Sacarose $0,5 \mathrm{mM}$ pH 8,0. Em seguida foi adicionada $22 \mu \mathrm{L}$ de água destilada gelada, misturada e incubada por 30 minutos em banho de gelo. Ao final da incubação a amostra foi centrifugada a 14.000 RPM por 20 minutos a $4^{\circ} \mathrm{C}$. O sobrenadante foi guardado.

\subsubsection{Extração da proteína recombinante por lise celular por sonicador}


A cultura bacteriana foi centrifugada a 8.000 RPM por 10 minutos a $4^{\circ} \mathrm{C}$. O pellet de bactérias formado foi ressuspendido em solução de tris- $\mathrm{HCl} 20$ mM, pH 7,5 e submetido à lise celular por sonicador por cinco vezes em banho de gelo, 30 segundos cada vez. Essa suspensão foi centrifugada a 8.000 RPM por 10 minutos a $4^{\circ} \mathrm{C}$. O sobrenadante contendo as proteí nas solúveis foi coletado. No caso do plasmídeo recombinante p1813_QM, o primeiro sobrenadante foi novamente centrifugado, nas mesmas condições da primeira, para uma maior limpeza da amostra (denominado sp1), o pellet foi novamente ressuspendido, sonicado uma vez por 30 segundos em gelo e centrifugado nas mesmas condições. O segundo sobrenadante foi denominado sp2.

\subsubsection{Purificação}

A partir dos extratos bacterianos as proteínas recombinantes foram purificadas por cromatografia.

A cromatografia é um dos métodos mais comuns de purificação de proteínas. Consiste na passagem de uma mistura protéica através de uma coluna (fase estacionária) que tem por objetivo reter ou diminuir a velocidade da passagem da fase móvel onde estão as macromoléculas (proteínas). A técnica a ser escolhida baseia-se numa propriedade particular da proteína, como o tamanho, carga ou afinidade química. A solução a analisar deve conter a proteína concentrada e o método deve ser rápido para evitar a degradação da mesma, devendo, no entanto, utilizar-se inibidores de proteases.

Neste trabalho, foram testados alguns protocolos utilizando diferentes resinas de purificação no intuito de aumentar a pureza das amostras.

A primeira metodologia utilizada foi a cromatografia por afinidade, que é uma técnica que utiliza propriedades físico-químicas para a separação. Proteínas com caudas de poli-histidinas possuem afinidade a metais, como 0 Níquel imobilizado na resina.

A resina foi carregada com solução fosfato de sódio $20 \mathrm{mM}$ e equilibrada com tampão tris- $\mathrm{HCl} 20 \mathrm{mM} \mathrm{pH} \mathrm{7,5.} \mathrm{As} \mathrm{cromatografias} \mathrm{foram}$ realizadas com fluxo de $1 \mathrm{~mL}$ por minuto. A coluna foi equilibrada com 5 volumes de coluna em tampão tris- $\mathrm{HCl} 20 \mathrm{mM} \mathrm{pH} \mathrm{7,5}$ e as soluções protéicas aplicadas, 
após lavagem com o mesmo tampão as proteínas foram eluídas com concentrações que variaram de $\mathrm{O}$ a $500 \mathrm{mM}$ de Imidazol.

A cromatografia de troca iônica baseia-se na carga da proteína em estudo. Se esta possuir carga positiva, a solução deve passar por uma coluna com carga negativa. A amostra se encontrava em tris- $\mathrm{HCl} \mathrm{pH} 7,5$ e a eluição foi feita utilizando um gradiente de $\mathrm{NaCl}$ de 0 a $1 \mathrm{M}$.

$\mathrm{Na}$ cromatografia em coluna hidrofóbica, a metodologia é fundamentada nas propriedades hidrofóbicas de algumas proteínas. Elas devem estar em elevada concentração de sal, o que aumenta a entropia da água, aumentando, assim, as interações hidrofóbicas. Na presença de elevadas concentrações de sal, os grupos fenil da matriz impedem a passagem de porções das proteínas hidrofóbicas. Pode-se controlar a separação de diferentes ligações à coluna das proteínas, reduzindo a concentração do sal ou adicionando solventes.

Utilizou-se como tampão inicial e de amostra tris- $\mathrm{HCl} 20 \mathrm{mM}$ com acetato de amônio $1 \mathrm{M}$. A eluição foi feita com um gradiente de acetato de amônio de 1 a $0 \mathrm{M}$ e em seguida um gradiente de tris $-\mathrm{HCl}$ de 20 a $0 \mathrm{mM}$, para retirada de qualquer proteína que possa ter ficado liga à resina.

$\mathrm{Na}$ cromatografia por exclusão molecular separa as proteínas de acordo com o tamanho. A coluna é constituída por uma matriz de pequenas esferas porosas empacotadas. Ao fazer passar a solução de proteínas pela matriz da coluna, as moléculas pequenas entram nos poros das esferas demorando a atravessá-los, enquanto que as grandes passam entre as esferas sendo separadas primeiro.

Essa purificação foi feita em tampão tris-HCl 20 mM com 150 mM de $\mathrm{NaCl}$ para possibilitar picos de eluição mais definidos.

As colunas His-Tag e Hi-Trap foram acopladas ao sistema Acta-FPLC e os procedimentos para as purificações seguiram as recomendações do fabricante, (Amershan/GE).

As amostras, tanto para QM expressa pelas bactérias transformadas com o vetor pET26_QM quanto pelo p1813_QM, foram purificadas nas três colunas acopladas ao Acta-FPLC. Somente a proteína produzida pelo plasmídeo recombinante p1813_QM, foi purificada em uma cromatografia por exclusão molecular. 


\subsubsection{Caracterização de QM}

\subsubsection{Eletroforese em gel de poliacrilamida (SDS-PAGE)}

A análise da proteína RP L10 foi realizada por eletroforese das amostras em gel de poliacrilamida SDS-PAGE (Sodium Dodecyl Sulphate Polyacrilamide Gel Electrophoresis) com gel de separação a $15 \%$ e o de empilhamento a 4\% (Laemmli, 1970). Foram analisadas as amostras de cultura bacteriana com e sem ativação por IPTG, amostras de ativação nos diferentes tempos e temperaturas, choque osmótico, lise por sonicação e amostras de purificação. As amostras foram aplicadas diretamente no gel e foram preparadas por mistura com o tampão de amostra 6x concentrado, o qual contém SDS e $\beta$ mercaptoetanol, aquecidas por 10 minutos a $95^{\circ} \mathrm{C}$.

A corrida foi feita em tampão de corrida tris/glicina/SDS, sob corrente de $25 \mathrm{~mA}$ em temperatura ambiente, até que o corante azul de bromofenol chegasse ao final do gel.

A coloração das proteínas separadas no gel foi realizada tratando-o com uma solução de Comassie durante 30 minutos e em seguida foi descorado em uma solução descorante, até visualização das bandas de proteína.

Após a coloração do gel, este foi fotografado e analisado com o programa ImageJ para quantificação da proteína expressa.

\subsubsection{Western blotting}

Após separação das proteínas por eletroforese em gel de poliacrilamida, elas foram transferidas para uma membrana de nitrocelulose pelo método semi-seco como descrito por Burnette (1981). Foram colocadas duas folhas de papel filtro pré-umedecidas em tampão de transferência $(0,3 \%$ glicina, 0,6\% tris-base, $0,04 \%$ SDS, $20 \%$ metanol) e em seguida, do pólo positivo para o pólo negativo, a membrana de nitrocelulose pré-umedecida, o gel e mais duas folhas de papel filtro pré-umedecidas. 
A corrente foi fixada de acordo com a área de gel $\left(0,85 \mathrm{~mA}\right.$ por $\left.\mathrm{cm}^{2}\right)$ para a transferência total das proteínas. A transferência foi realizada por uma hora.

Após lavar a membrana com solução de PBS e leite desnatado (Molico) $5 \%$, esta foi incubada com anticorpo policlonal contra a proteína QM, em uma diluição 1:200 em PBS + leite durante 16 horas em gelo com agitação lenta. Em seguida a membrana foi lavada cinco vezes com a solução de PBS + leite desnatado $5 \%$ e incubada com anticorpo conjugado marcado com HRP, em uma diluição de 1:2000 em PBS + leite desnatado 5\%, por 1 hora em gelo com agitação lenta. Após a incubação, a membrana foi lavada 5 vezes com PBS + leite e duas vezes só com PBS. A detecção da proteína de interesse foi feita utilizando o KitECL (GE) e as membranas foram expostas a filmes radiográficos, os quais foram revelados.

\subsubsection{Dosagem de QM expressa pelos vetores}

O método utilizado para determinação do conteúdo protéico com o objetivo de avaliar o rendimento da expressão foi o descrito por Bradford (1976). Este método baseia-se na capacidade do corante Comassie Blue R-250 se ligar às proteínas, em meio ácido, resultando na modificação proporcional da cor, detectável em $595 \mathrm{~nm}$.

Uma curva padrão com zero a $25 \mu \mathrm{g}$ de albumina bovina sérica (BSA) foi feita para cada experimento. Às amostras de volume de $200 \mu \mathrm{L}$ em solução salina foram adicionados $800 \mu \mathrm{L}$ do corante Comassie para ensaio de Bradford. A dosagem foi feita por leitura da absorbância em $\star 595 \mathrm{~nm}$.

As amostras foram todas preparadas nas mesmas condições. Após 10

minutos, à temperatura ambiente, foi medida a densidade ótica em espectrofotômetro em $\lambda 595 \mathrm{~nm}$. Todos os pontos foram feitos em triplicata e os dados geraram uma curva padrão que foi utilizada para cálculo das dosagens das amostras. 


\subsubsection{Caracterização estrutural}

\subsubsection{Dicroísmo circular (CD)}

Para verificar se as proteínas recombianantes possuíam estrutura secundária correta, foram realizados experimentos de dicroísmo circular.

Esta é uma técnica que permite obter dados da composição de estrutura secundária de proteínas ( $\alpha$-hélice e conformações $\beta$ ). As análise foram feitas em concentrações de proteína pura entre 100 a $500 \mu \mathrm{g} / \mathrm{mL}$ em tampão tris$\mathrm{HCl} 20 \mathrm{mM} \mathrm{pH} 7,5$. Os espectros foram coletados entre os comprimentos de onda de $\lambda 190$ a $260 \mathrm{~nm}$, em intervalos de $0,5 \mathrm{~nm}$, com 4 leituras acumuladas para se obter uma média entre os espectros. O caminho óptico utilizado foi $1 \mathrm{~mm}$. As análises dos resultados do CD foram feitas com o programa CDNN (Bohm e cols., 1992).

Além do ensaio de caracterização, foi feita uma avaliação da ação do reagente Guanidina em diferentes concentrações: $0 \mathrm{M}, 10 \mathrm{mM}, 25 \mathrm{mM}, 50 \mathrm{mM}$, $75 \mathrm{mM}, 100 \mathrm{mM}, 500 \mathrm{mM}$ e $1 \mathrm{M}$, essas diferentes concentrações foram adicionadas à amostra de QM que ficaram incubando por 15 minutos antes da leitura do espectro.

\subsubsection{Fluorescência}

Foram feitos ensaios de Fluorescência que permitiram estudar a conformação terciária da proteína, por emissão de fluorescência dos triptofanos presentes na mesma. Com esta técnica foi estudada a incorporação de íons Zinco, que sabidamente estão ligados à proteína QM e que desempenham uma ação importante na atividade da proteína quando esta interage com a proteína Jun.

As amostras de proteína pura em concentrações variando entre 100 a

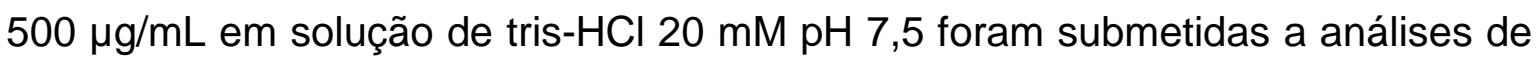
Fluorescência. O comprimento de onda de excitação foi $280 \mathrm{~nm}$ e os espectros de fluorescência foram coletados entre os comprimentos de onda de $\star 300$ a $400 \mathrm{~nm}$. 
Nesse ensaio também foi feita a curva com Guanidina da mesma maneira realizada para o ensaio de CD. 


\section{RESULTADOS}

\subsection{Clonagem}

No intuito de compararmos a eficiência da expressão da proteína QM em bactérias transformadas com vetores de expressão periplásmica, foi realizada uma clonagem do cDNA para a proteína QM no vetor p3SN8. Este vetor foi escolhido por já ter demonstrado uma boa expressão de proteínas recombinantes como abg, phoa e o hormônio Prolactina (Grahan, 1995, Morganti e cols., 1996).

Para a clonagem no vetor p3SN8 foram desenhadas duas seqüências de primers contendo os sítios de restrição que possibilitariam a inserção do cDNA no vetor.

Para a amplificação do cDNA para a proteína QM foi utilizado como DNA molde o vetor pET26_QM (QM já havia sido clonado neste vetor antes do presente estudo).

Após a amplificação do cDNA para a proteína QM, ele foi clivado com as enzimas de restrição Nhe I e Bam HI. O vetor p3SN8 também foi clivado com as mesmas enzimas e em seguida foi defosforilado com a enzima CIP para que não houvesse a possibilidade de união das duas extremidades que foram abertas, FIGURA 5. 


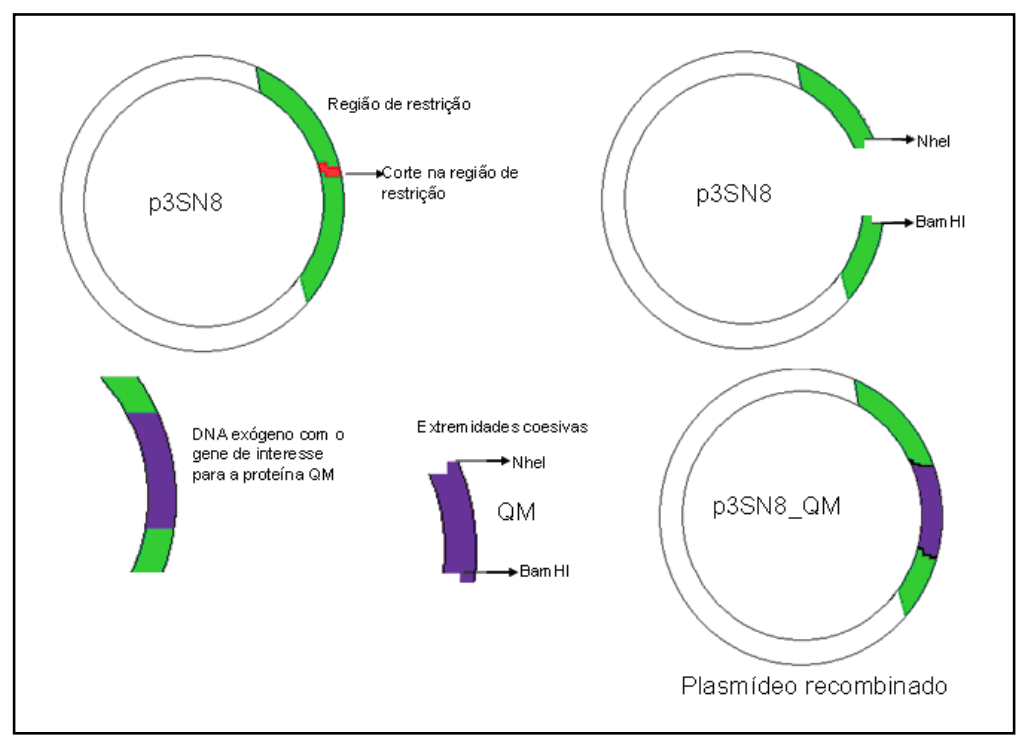

FIGURA 5: Esquema da clonagem em p3SN8.

$\mathrm{Na}$ FIG. 6 encontra-se uma foto de gel de agarose onde pode ser observado o vetor p3SN8 de $5 \mathrm{Kpb}$ (coluna 1) e inserto de 680 pb (colunas 2 e 3). A clonagem produziu três clones que, após mapa de clivagem com as enzimas PST I e Hind III, foram confirmados serem positivos.

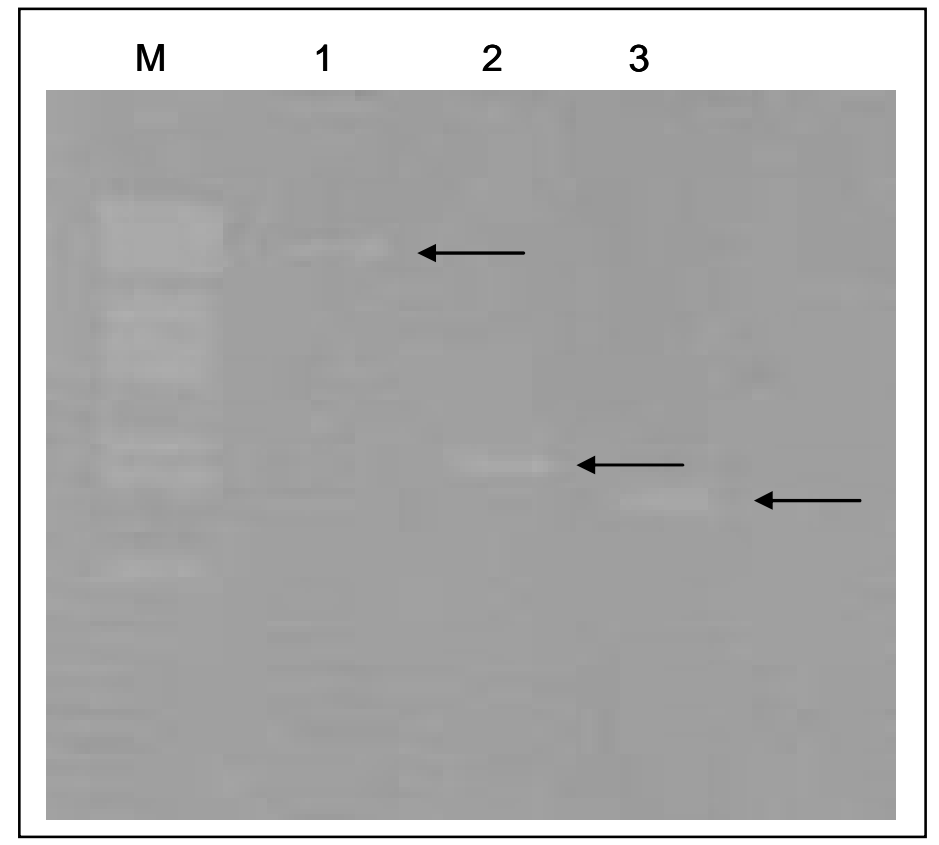

FIGURA 6: Inserto e vetor p3SN8.

Foi realizada uma eletroforese em gel de agarose $1 \%$ e o DNA foi corado com solução de Brometo de Etídio. M, marcador de massa molecular; coluna 1, vetor p3SN8 digerido e purificado; coluna 2, fragmentos de cDNA de QM sem digestão (controle); coluna 3, QM digerido e purificado. 
O plasmídeo recombinante foi introduzido em uma cepa de E.coli, HB2151 quimicamente competente. Esta cepa é importante porque possibilita a expressão de proteínas recombinantes quando transformadas com este vetor, o que não ocorre na cepa BL21 (DE3).

\subsection{Expressão de QM}

\subsubsection{Padronização das condições de ativação na expressão da proteína humana recombinante $Q M$}

\subsubsection{Expressão Periplásmica}

Nos primeiros ensaios de expressão da proteína foram utilizados os dois vetores, pET26_QM e p3SN8_QM; utilizando na ativação da expressão protéica $0,5 \mathrm{mM}$ de IPTG em uma temperatura de $37^{\circ} \mathrm{C}$ por 4 a 7 horas. Neste ensaio não houve produção da proteína recombinante (dados não mostrados).

Para analisar a influência da temperatura e aperfeiçoar a expressão da proteína humana QM, decidiu-se padronizar as condições de expressão da mesma, diminuindo a temperatura para $30^{\circ} \mathrm{C}$ e analisa ndo a expressão ao longo de 25 horas.

A expressão da proteína recombinante foi confirmada na forma solúvel pelas análises em SDS-PAGE e Western blotting (FIG. 7), mas, somente em bactérias transformadas com o vetor pET26_QM.

A maior quantidade de expressão foi encontrada nos tempos 15 horas, 20 horas e 25 horas, não havendo grandes diferenças entre os tempos, optou-se por padronizar o tempo em 15 horas de incubação FIG. 8.

Não foi conseguido confirmar pelo ensaio de Western blotting a expressão da proteína QM em bactérias transformadas pelo vetor p3SN8 (dados não mostrados), por isso decidimos continuar os ensaios apenas com o vetor pET26b_QM. 

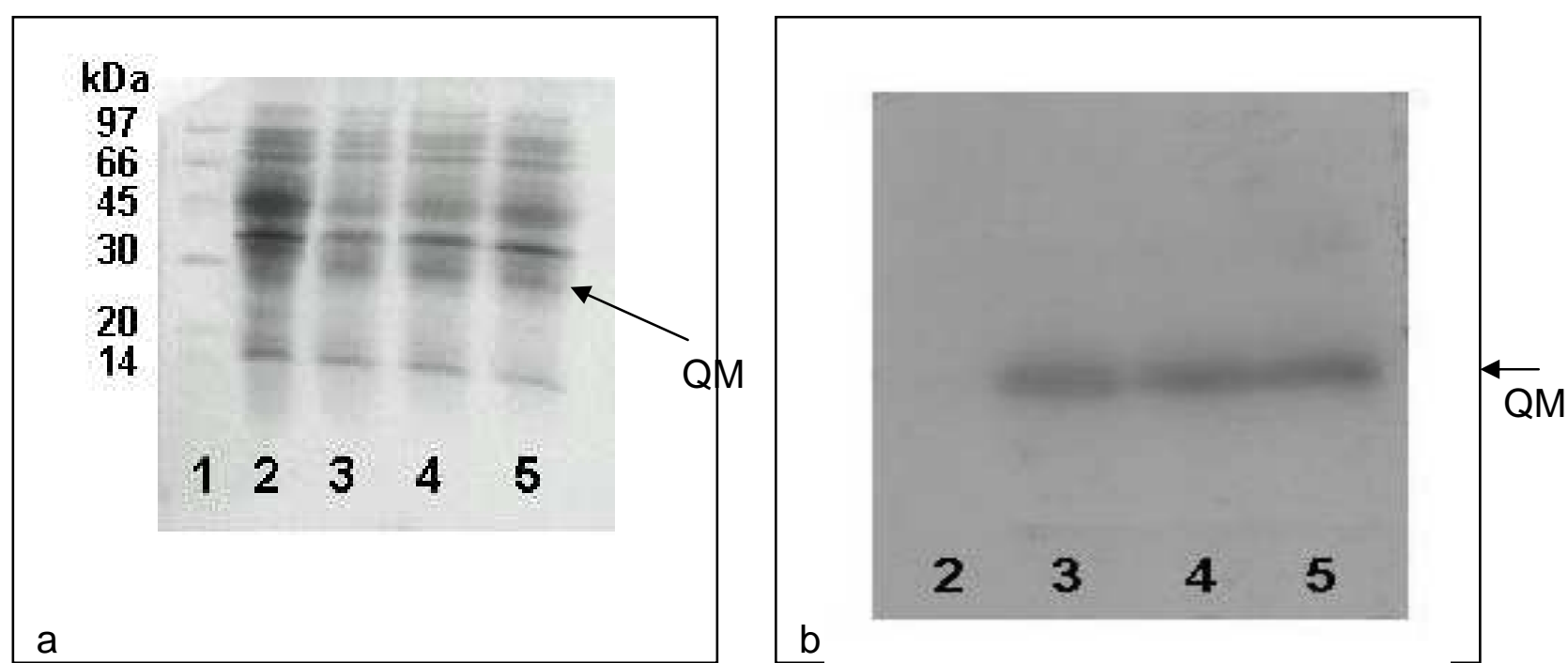

FIGURA 7: Análise da expressão da proteína QM por SDS_PAGE (a) e Western blotting (b).

Coluna 1, marcador de massa molecular;a) e b) coluna 2, cultura não induzida; colunas 3, 4 e 5 culturas ativadas por 15, 20 e 25 horas, respectivamente.

A partir desses dados, foi padronizado o protocolo de expressão de pET26_QM no espaço periplásmico da bactéria, sendo a condição mais adequada para os experimentos e que mantinham a mesma expressão de QM: a ativação a $30^{\circ} \mathrm{C}$ em 16 horas, FIG. 8.

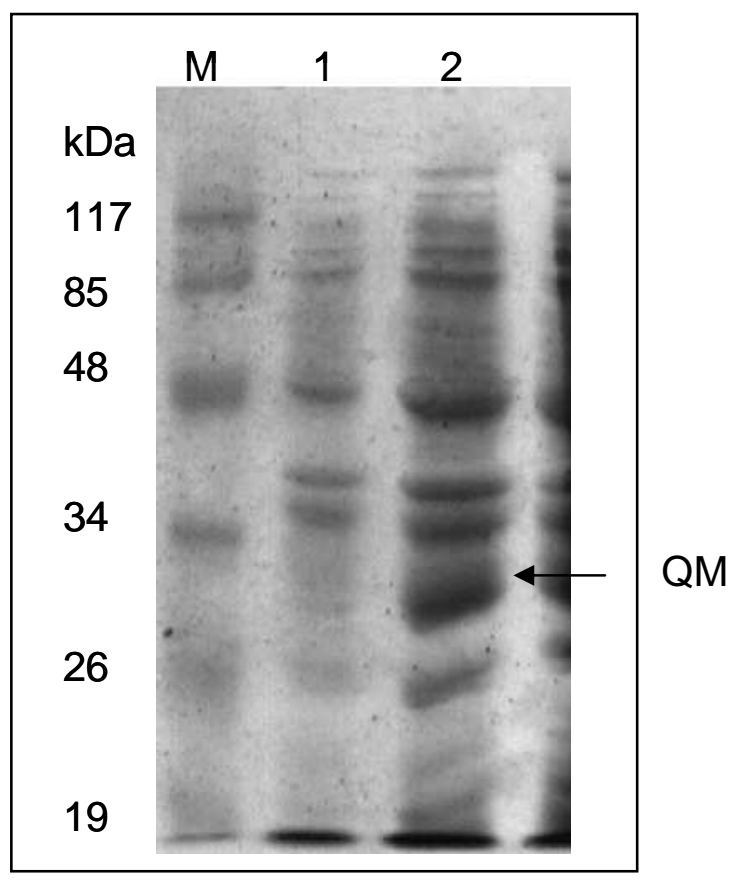

FIGURA 8: Expressão de QM por bactérias transformadas com pET26_QM a $30 \mathrm{C}$ por 16 horas. 
M, marcador de massa molecular, coluna 1, pET26_QM sem ativação, coluna 2 pET26_QM ativado a 30ำ por IPTG por 16 horas.

\subsubsection{Expressão Citoplásmica}

Para o plasmídeo recombinante p1813_QM a ativação foi feita por 16 horas com $0,5 \mathrm{mM}$ de IPTG em diferentes temperaturas, ${ }^{\circ}{ }^{\circ} \mathrm{C}, 25^{\circ} \mathrm{C}, 30^{\circ} \mathrm{C}, 3^{\circ} \mathrm{C}$ e $42^{\circ} \mathrm{C}$, nesse caso, só havia interesse na proteína que estivesse solúvel, por isso essas temperaturas foram testadas. A expressão da proteína recombinante foi confirmada na forma solúvel pelas análises em SDS-PAGE (FIG. 9).

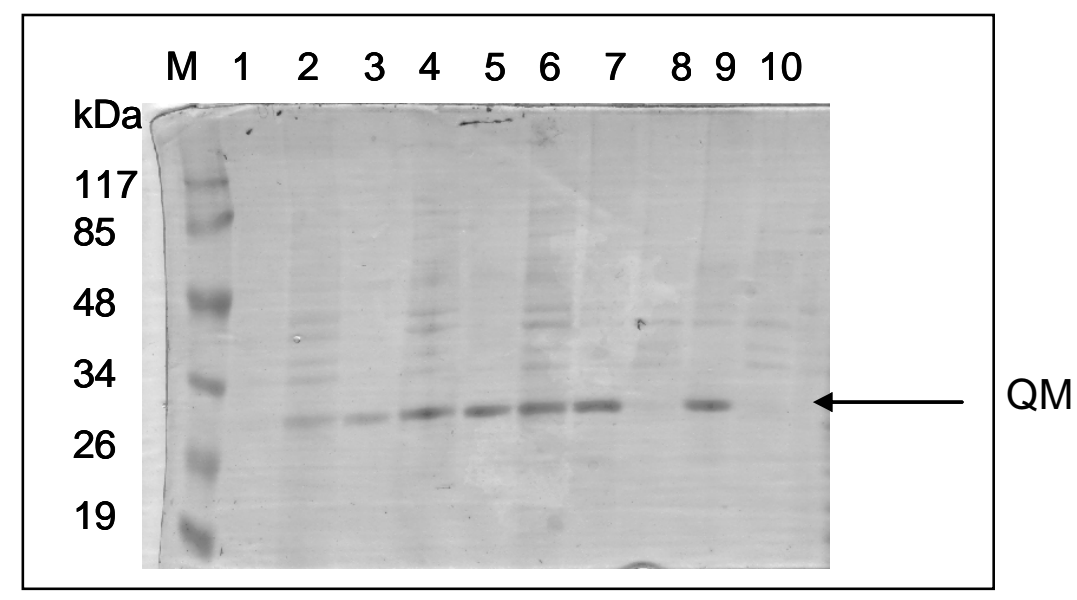

FIGURA 9: Expressão de QM citoplasmático em bactérias transformadas com p1813 em diferentes temperaturas de ativação.

$M$, marcador de massa molecular, colunas 1 e 2, pellet e sobrenadante da ativação a $18 \mathrm{C}$, respectivamente; colunas 3 e 4 , pellet e sobrenadante da ativação a $25 \mathrm{C}$; colunas 5 e 6 , pellet e sobrenadan te da ativação a $300^{\circ}$; colunas 7 e 8, pellet e sobrenadante da ativação a 37C; colunas 9 e 10, pellet e sobrenadante da ativação a $42 \mathrm{C}$.

A partir desse SDS-PAGE, foi possível observar que dos $18^{\circ} \mathrm{C}$ até os $3^{\circ} \mathrm{C}$ há um aumento gradativo de proteína solúvel em comparação com a quantidade não solúvel (colunas 2, 4 e 6), a partir dos $37^{\circ} \mathrm{C}$, esse padrão parece se inverter, com queda de níveis de proteína solúvel. Além da quantidade de proteína QM expressa, ser bem significativa, embora aqui ainda não haja 
quantificação, as amostras parecem apresentar menos contaminantes do que no periplasma, podendo ser purificada diretamente desta etapa.

A partir desse ensaio, decidiu-se que as ativações de p1813_QM seriam realizadas em ${ }^{2} 5^{\circ} \mathrm{C}$ e $30^{\circ} \mathrm{C}$ devido a quantidad e de proteína solúvel produzida.

\subsubsection{Extração da proteína QM recombinante do espaço periplásmico}

A proteína QM foi isolada do espaço periplásmico por choque osmótico e sonicação. Foram testados quatro protocolos de choque osmótico.

Os trabalhos de recuperação da proteína de interesse por choque osmótico iniciaram-se pelo protocolo descrito por Koshland \& Botstein (1980), que utiliza o volume de $5 \mathrm{~mL}$ de recuperação de proteína, como pode ser observado na coluna 2 (FIG. 10).

A quantidade de proteína extraída do choque foi muito pequena, tanto que, só foi detectada pelo ensaio de Western blotting, que é uma técnica bastante sensível, portanto decidiu-se testar o mesmo protocolo com diferentes volumes de recuperação de amostra para tentar concentrá-la a ponto de ser visível em SDSPAGE.

Os volumes originais de recuperação nesse protocolo foram reduzidos a metade. Na FIG. 10, estão representadas as três metodologias empregadas para aumentar a eficiência de recuperação da proteína QM no choque osmótico. Metodologias: (A) volumes solução de sacarose e $\mathrm{MgCl}_{2}$ como os utilizados no trabalho de Koshland \& Botstein (1980). (B) volume de sacarose igual a (A), volume de $\mathrm{MgCl}_{2}$ reduzido a metade. (C) volumes de sacarose e $\mathrm{MgCl}_{2}$ reduzidos a metade.

Na coluna 2 desta figura está representada a amostra obtida a partir de choque osmótico de (A). Na coluna 3, (B) promovendo uma maior concentração da amostra, enquanto na coluna $4(\mathrm{C})$ e, neste último, o resultado obtido foi uma menor recuperação da proteína de interesse. 


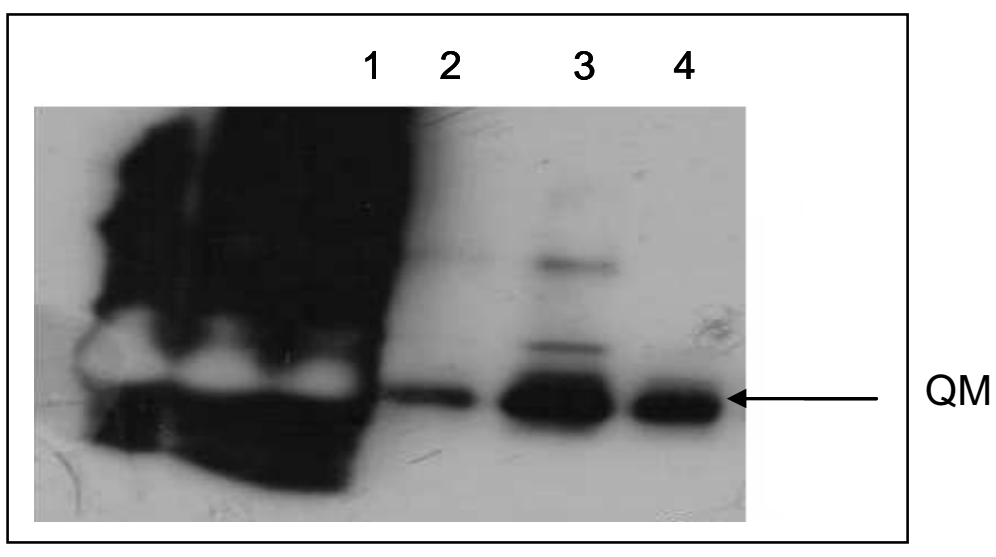

FIGURA 10: Análise de Western blotting das frações periplásmicas.

Coluna 1, cultura ativada; coluna 2, choque osmótico com $5 \mathrm{~mL}$ de solução de $\mathrm{MgCl}_{2}$; coluna 3, choque osmótico concentrado; coluna 4, choque osmótico com $2,5 \mathrm{~mL}$ de solução $\mathrm{MgCl}_{2}$

Mesmo assim, a quantidade de proteína recombinante obtida a partir desse protocolo de choque osmótico, foi extremamente baixa, tanto que em todos os casos a proteína só foi detectada por Western blotting, o que ainda era insuficiente para os ensaios posteriores de purificação.

Com o intuito de aumentar essa eficiência da extração da proteína QM, foi testado um protocolo de choque osmótico em que se adicionava a enzima lisozima na etapa da adição da solução de sacarose. A lisozima adicionada nesta etapa do choque possibilita maior liberação da proteína no espaço periplásmico. Na FIG. 11, comparando-se as colunas 1 e 2, onde se encontram as amostras de cultura total ativada e choque com uso de lisozima, respectivamente, aqui a recuperação da proteína QM também é bastante baixa.

Foi testado um protocolo de fácil execução, que utiliza bem pouca amostra, descrito por Brojaliloo e cols. (2003), infelizmente não foi obtido resultado positivo neste Western blotting (coluna 3 ). 


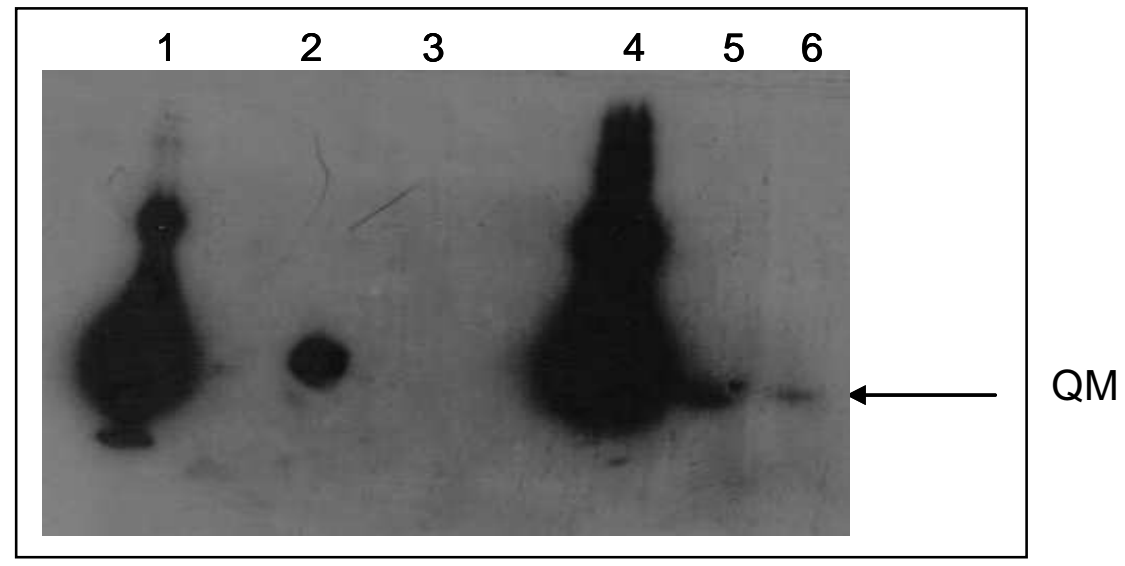

FIGURA 11: Análise de Western blotting das frações periplásmicas.

Coluna 1, Cultura induzida; coluna 2, choque osmótico com lisozima (Matsushita e cols., 1981); coluna 3, choque osmótico feito a partir do protocolo descrito por Borjailoo e cols. (2003); coluna 4, amostra sonicada; coluna 5, choque osmótico segundo o protocolo descrito por Soares e cols. (2003); coluna 6: choque osmótico segundo o protocolo Koshland.

Ainda na FIG. 11, coluna 4, pode-se observar o primeiro experimento de extração da proteína QM por sonicação. Neste resultado de Western blotting observa-se claramente a diferença entre a recuperação da proteína QM por choque e sonicação nas colunas 2 e 4, respectivamente. Com uma obtenção muito maior de proteína no último caso, sendo bem próxima da quantidade de proteína produzida na cultura induzida (coluna 1).

As colunas 5 e 6 são resultados positivos de choque osmótico, embora em quantidades muito insignificantes.

A exposição em radiografia foi deixada por um tempo maior do que 0 usual para a detecção das amostras de choque osmótico (que se apresentavam em baixa quantidade); e neste caso, as amostras de cultura induzida e material sonicado ficaram muito intensas.

Em análise por Western blotting, claramente se vê a grande quantidade de proteína QM que foi extraída por meio do ensaio de sonicação (FIG. 10 e 11), porém em análise por SDS-PAGE havia muitas outras proteínas contaminantes (FIG. 12), o que não era interessante para etapa de purificação. 
Visando reduzir a quantidade desses contaminantes, foi introduzida uma etapa de ultracentrifigação (30.000 RPM por duas horas) após a centrifugação normal do protocolo (10.000 RPM por 10 minutos).

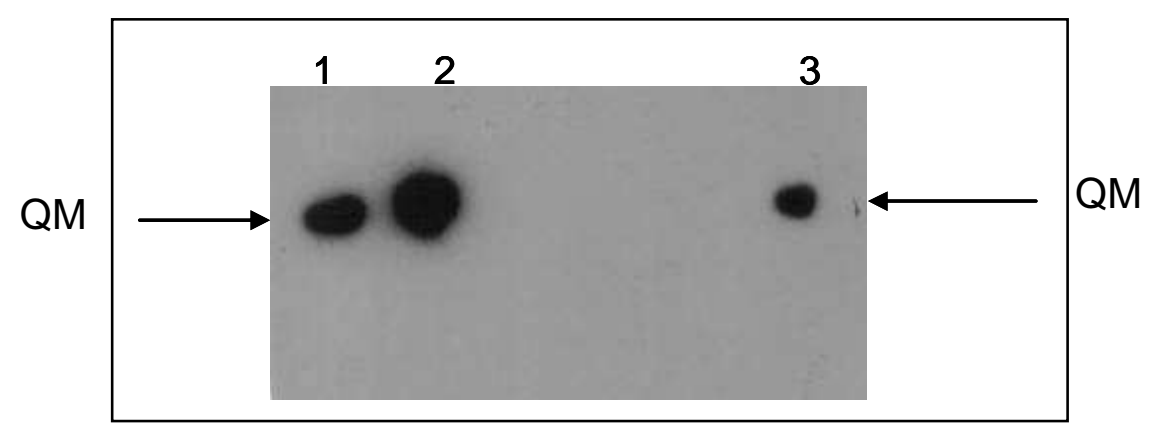

FIGURA 12: Análise em Western blotting de QM produzido por bactérias ativadas com IPTG a $30^{\circ} \mathrm{C}$ por 16 horas.

Coluna 1, Cultura não ativada; coluna 2, cultura ativada sonicada em tris- $\mathrm{HCl} 20$ $\mathrm{mM}$ pH7,5 (amostra com beta mercaptol); coluna 3, cultura ativada sonicada em

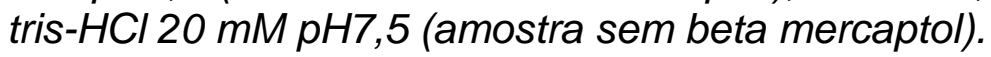

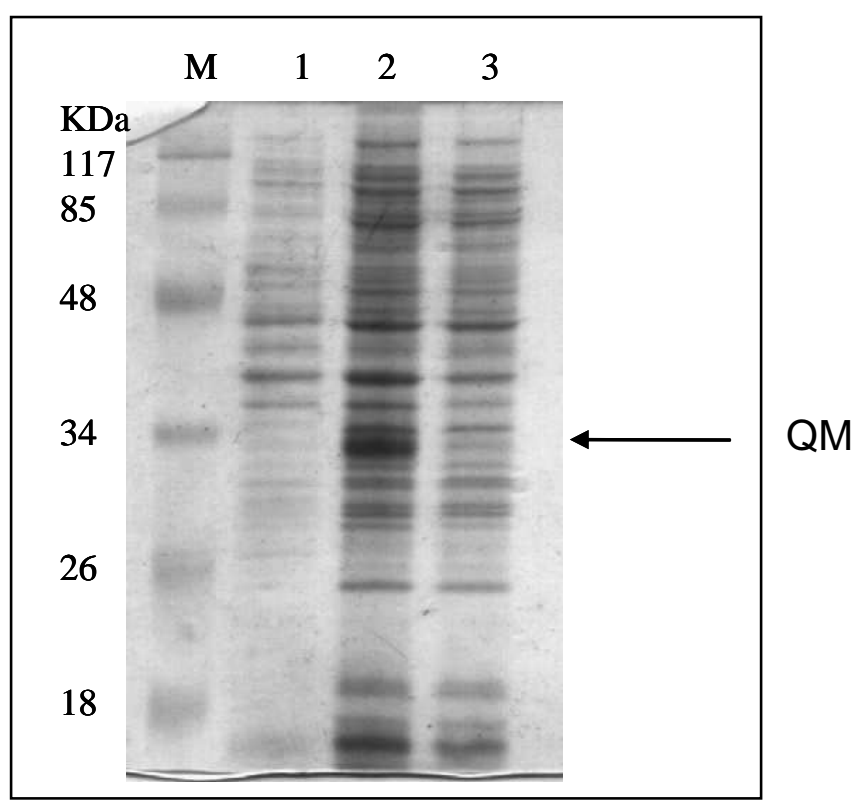

FIGURA 13: Análise em SDS-PAGE de QM com ultracentrifugação.

$M$, marcador de massa molecular; Coluna 2, cultura não ativada; coluna 3, cultura ativada sonicada em tris- $\mathrm{HCl} 20 \mathrm{mM} \mathrm{pH} \mathrm{7,5;} \mathrm{coluna} \mathrm{4,} \mathrm{sobrenadante} \mathrm{da}$ ultracentrifugação. 
De acordo com a FIG. 13, o que pode ser observado é que o processo de ultracentrifugação não foi eficiente para limpar a amostra, pois houve uma redução na quantidade das proteínas totais, inclusive na QM. De acordo com esse resultado, este protocolo foi ineficiente.

\subsubsection{Quantificação de QM}

A quantificação da proteína recombinante QM foi realizada a partir de culturas ativadas e do total de proteínas solúveis obtidas por sonicação. O ensaio de quantificação foi realizado a partir da caracterização da proteína em gel de poliacrilamida $15 \%$, esse gel foi escaneado e analisado pelo programa ImageJ, que gera um gráfico da área da corrida da amostra.

Cada pico do gráfico é específico de uma proteína. A partir da área do pico do QM, foi possível quantificá-lo no gel, através da seguinte proporção: área do pico da proteína QM / área da corrida total. A partir desse valor em porcentagem, quantificamos a amostra pelo método descrito por Bradford (1976), no qual foi possível obter a quantidade protéica da amostra em massa/volume.

Foi quantificada a expressão de QM pelas bactérias transformadas com o plasmídeo recombinante pET26_QM (extrato cru e proteína solúvel) e p1813_QM, nesse último, foi quantificada a proteína no extrato cru e a proteína solúvel nas etapas de centrifugação do sobrenadante. 


\subsubsection{Quantificação de QM produzido pelas bactérias transformados com o vetor PET26_QM}

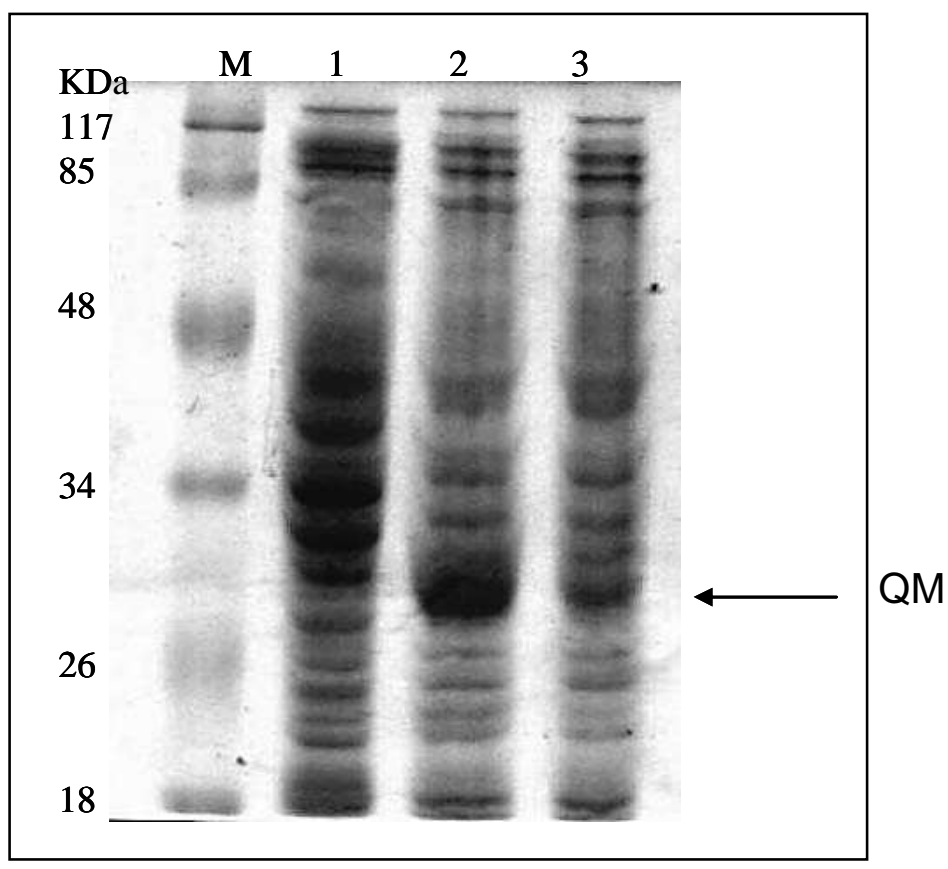

FIGURA 14: Gel de SDS-PAGE com amostras da expressão de QM pelas bactérias transformadas pelo vetor pET26_QM, utilizado para quantificação por Bradford.

M: marcador de massa molecular, coluna 2, cultura transformada com o vetor pET26_QM sem ativação por IPTG; coluna 3, cultura transformada com o vetor pET26_QM ativado por IPTG por 16h; coluna 4, sobrenadante da cultura transformada com o vetor pET26_QM sonicada em tris-HCl 20 mM ph 7,5.

Para o ensaio de Bradford foi necessária a construção de uma curva de padronização que foi feita com Soro Albumina Bovina (BSA). Esta curva foi feita em cada ensaio e um exemplo de uma das curvas obtidas pode ser observado na FIGURA 14. Esta curva serviu para obtenção dos valores em $\mathrm{mg} / \mathrm{mL}$ de proteína total obtida nos experimentos de ativação da proteína QM. 


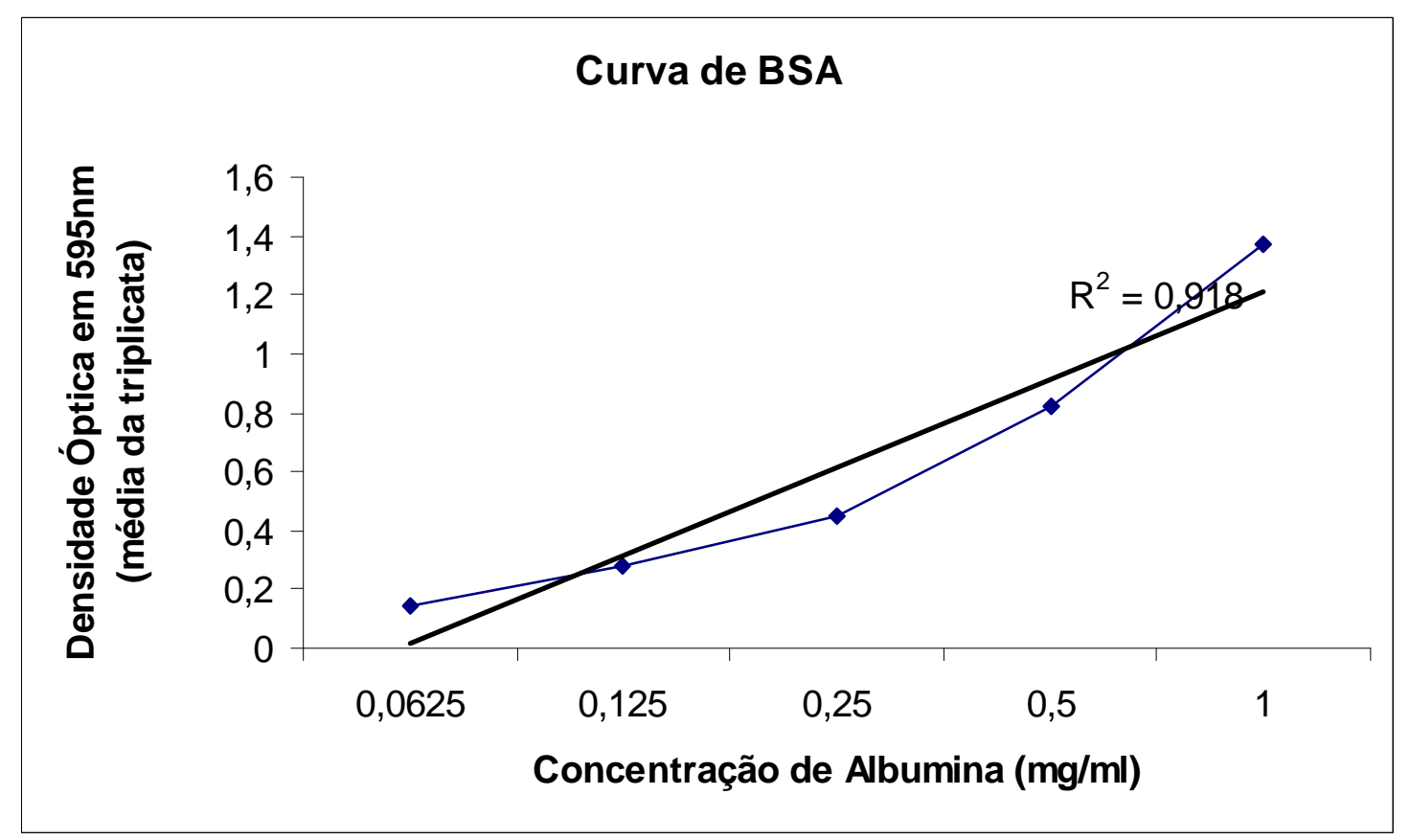

FIGURA 15: Curva de concentração de albumina para padronização do ensaio de Bradford.

Depois de quantificar a proteína total, a próxima etapa foi quantificar a proteína QM, especificamente, havia na amostra, essa quantificação foi feita a partir da leitura das proteínas (bandas) contidas em cada coluna do gel de SDSPAGE. Esta metodologia permite obter o valor em porcentagem de cada proteína contida na amostra em relação ao total protéico da coluna analisada.

Na FIG. 16 estão os gráficos obtidos com essa metodologia referentes ao gel da FIG. 14. 


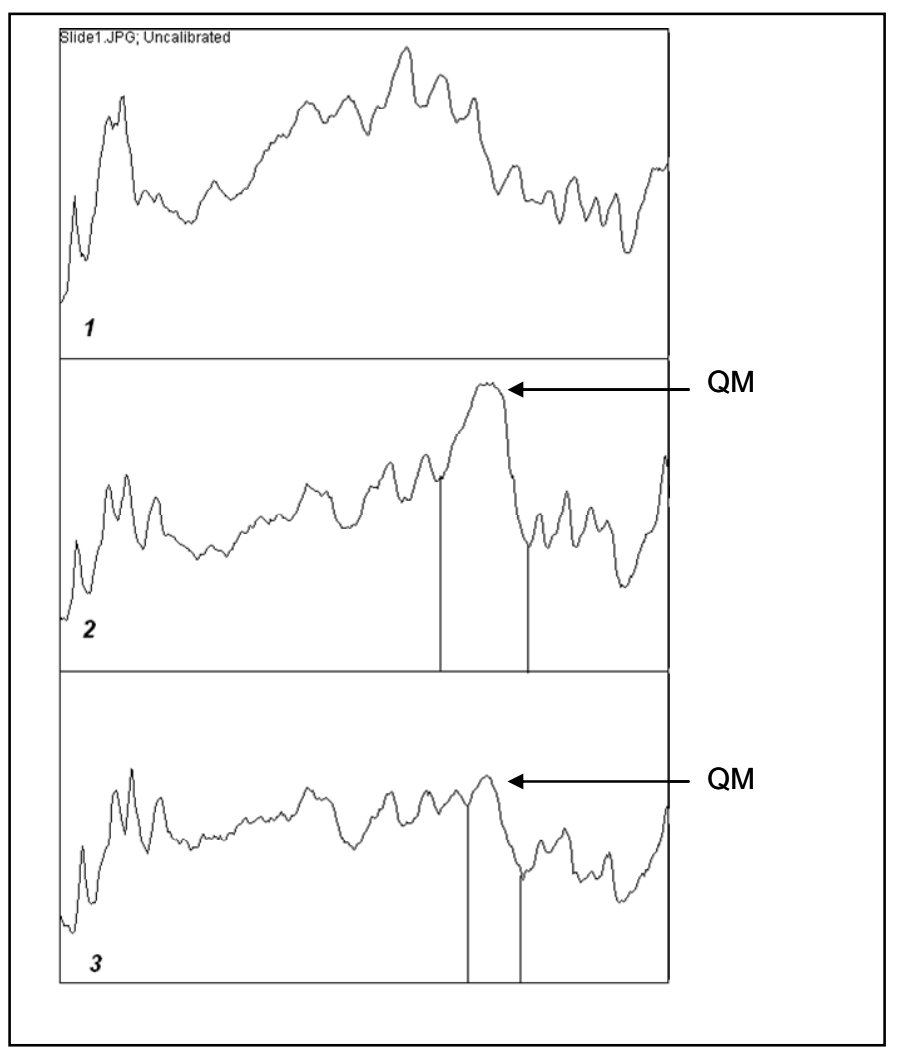

FIGURA 16: Imagem dos gráficos gerada a partir do programa ImageJ.

Gráfico 1 representa a corrida em SDS-PAGE de amostra de cultura com o vetor pET26_QM sem ativação por IPTG; gráfico 2, representa corrida em SDS-PAGE de amostra de cultura com o vetor $P E T 26$ _QM ativado por IPTG por 16 horas e no gráfico 3 a corrida em SDS-PAGE de amostra do sobrenadante de cultura com o vetor pET26_QM ativada por 16 horas e sonicada em tampão tris- $\mathrm{HCl} 20 \mathrm{mM} \mathrm{pH}$ 7,5. As áreas em destaque representam a quantidade da proteína $Q M$ que foi expressa.

O pico referente à proteína QM foi identificado utilizando a primeira imagem, que é um controle negativo, portanto não há QM na amostra. O pico que aparece nos dois últimos gráficos e não aparece no primeiro é, portanto, referente ao pico da proteína em questão.

A partir desses dados, tanto da imagem do gel, quanto do gráfico, fica evidente que há uma perda de proteína na sonicação.

No gráfico 2, FIG. 16, a área total calculada foi 68651 e, a área do pico de QM foi equivalente a 4669 (valores gerados pelo programa ImageJ), portanto a porcentagem de QM na amostra total foi de 6,8. 
As porcentagens da proteína QM obtidas pelos gráficos acima descritos, foram aplicadas na quantificação feita pelo método de Bradford, para o cálculo de QM no total de proteínas em cada amostra

No ensaio de Bradford, foi obtido uma quantificação de aproximadamente 0, $129 \mathrm{mg} / \mathrm{mL}$ de proteína QM na amostra total, TABELA 1, este valor é referente a $6,8 \%$ do total de proteínas da bactéria, conclui-se que há em torno de $0,13 \mathrm{~g} / \mathrm{L}$ na amostra total, o que significa uma quantidade satisfatória. A amostra foi analisada por Western blotting confirmando que a proteína está na sua forma solúvel.

TABELA 1: Quantificação de QM pelo método de Bradford

\begin{tabular}{cc}
\hline $\begin{array}{c}\text { Média da DO em } \\
595 \mathrm{~nm}\end{array}$ & $\begin{array}{c}\text { Média da quantificação de QM } \\
(\mathrm{mg} / \mathrm{mL})\end{array}$ \\
\hline 0,29 & 0,129 \\
\hline
\end{tabular}

\subsubsection{Quantificação de QM produzido pelas bactérias transformadas com o vetor p1813_QM}

A quantificação da proteína QM expressa pelas bactérias transformadas com o vetor p1813_QM foi feita em diferentes temperaturas de ativação, o que se pôde observar foi um aumento da concentração de proteína na fração solúvel, até a temperatura de $30^{\circ} \mathrm{C}$.

Na FIG. 17, nas colunas 1 e 2, ativação a $1^{\circ} \mathrm{C}$, obs erva-se que não há banda referente à proteína no pellet e há uma pequena quantidade na fração solúvel, nas colunas 3 e 4 , ensaio a ${ }^{\circ} 5^{\circ}$, há prote ína no pellet e na fração solúvel, um pouco mais nessa última, nas colunas 5 e 6 , ensaio a $30^{\circ} \mathrm{C}$, o que se pôde observar é que houve um aumento na produção da proteína tanto no pellet quanto na fração solúvel. Nas colunas 7 e 8 , ensaio a $37^{\circ} \mathrm{C}$, há um pico bastante expressivo no pellet o mesmo ocorre nas colunas 9 e 10, referentes ao ensaio a $42^{\circ} \mathrm{C}$. 


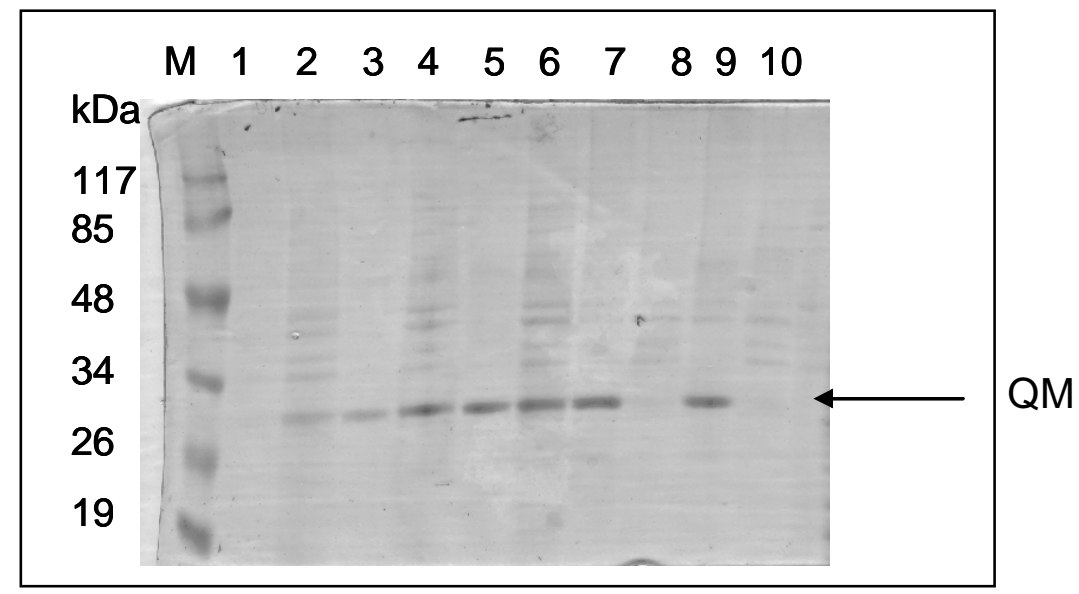

FIGURA 17: Gel de SDS-PAGE com amostras de expressão de QM produzido pelas bactérias transformadas com o vetor p1813_QM em diferentes temperaturas de ativação utilizado na quantificação de proteínas solúvel pelos métodos de Bradford e ImageJ.

A partir desses dados foi possível perceber que as ativações a $25^{\circ} \mathrm{C}$ e $30^{\circ} \mathrm{C}$ produziram maior quantidade de proteína no cit oplasma bacteriano portanto, decidimos fazer um ensaio de Bradford para análise da produção de QM nas duas temperaturas e decidir qual temperatura de ativação seria utilizada.

Nesse experimento, utilizamos três amostras de cada uma das duas temperaturas, a amostra extrato cru (EC), que é a obtida logo após a sonicação, como descrito em Metodologias, a amostra sobrenadante do pellet 1 (sp1), que é o sobrenadante da primeira centrifugação, o pellet gerado por essa centrifugação foi sonicado mais uma vez e centrifugado, dando origem à amostra sobrenadante do pellet 2 (sp2). 


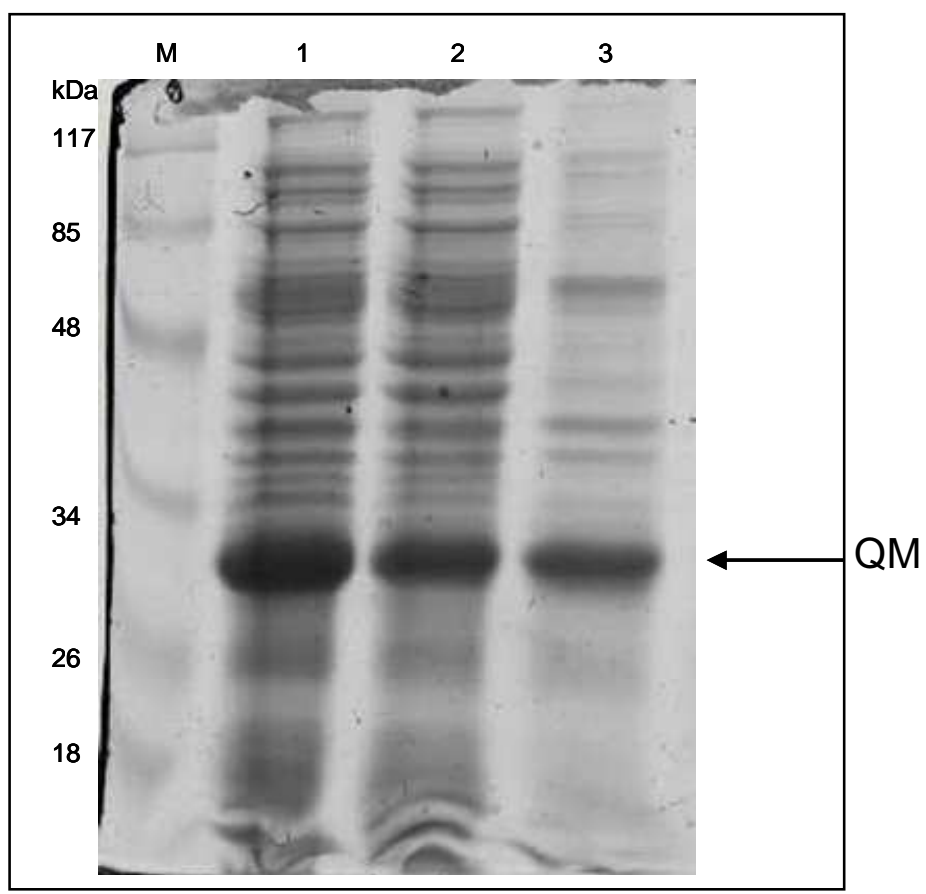

FIGURA 18: Expressão da proteína QM pelas bactérias transformadas com o vetor recombinante $p 1813$ QM ativadas a temperatura de $25^{\circ} \mathrm{C}$.

M: marcador de massa molecular; coluna 1, extrato cru; coluna 2, amostra de sp1 e; coluna 3, amostra de sp2.

TABELA 2: Porcentagem de QM na amostra de proteína produzida no citoplasma

\begin{tabular}{ccc}
\hline $\begin{array}{c}\text { Amostra de } \\
\text { QM }\end{array}$ & $\begin{array}{c}\text { Média da porcentagem de QM no } \\
\text { total da amostra }\end{array}$ & $\begin{array}{c}\text { Desvio } \\
\text { padrão }\end{array}$ \\
\hline EC & $26,14 \%$ & 1,5 \\
sp1 & $18,37 \%$ & 2,2 \\
sp2 & $31,7 \%$ & 2,3 \\
\hline
\end{tabular}

$\mathrm{Na}$ Tabela 2 pode-se observar a porcentagem obtida em cada banda de QM referente ao total calculado para cada coluna lida no gel de SDS-PAGE.

Na FIG 18, em todas as amostras de proteínas analisadas, a que se apresenta em maior quantidade é a proteína QM.

No extrato cru analisado há uma produção de $26,14 \%$ de QM, como a quantidade de contaminantes vai diminuindo a cada centrifugação a tendência é que a porcentagem de QM aumente, em compensação é bem provável que haja 
perdas nesses processos, inclusive precipitação de proteína que não esteja solúvel e que, portanto, não é de interesse, provavelmente por isso o valor encontrado em sp1 é menor. Em sp2, como visto nos géis anteriores, a amostra está bem limpa de contaminantes e em destaque está a proteína QM.

De posse desses dados, foi realizada uma quantificação de proteínas totais do espaço citoplásmico produzidas nas duas temperaturas analisada $\left(25^{\circ} \mathrm{C}\right.$ e $30^{\circ} \mathrm{C}$ ) pelo ensaio de Bradford e de QM pela anális e do SDS-PAGE.

$\mathrm{Na}$ FIG. 19 encontram-se amostras de culturas ativadas a $2^{\circ} \mathrm{C}$ e $300^{\circ} \mathrm{C}$, analisadas em SDS-PAGE. Nela é possível observar que a quantidade de contaminantes se reduz a cada centrifugação feita.

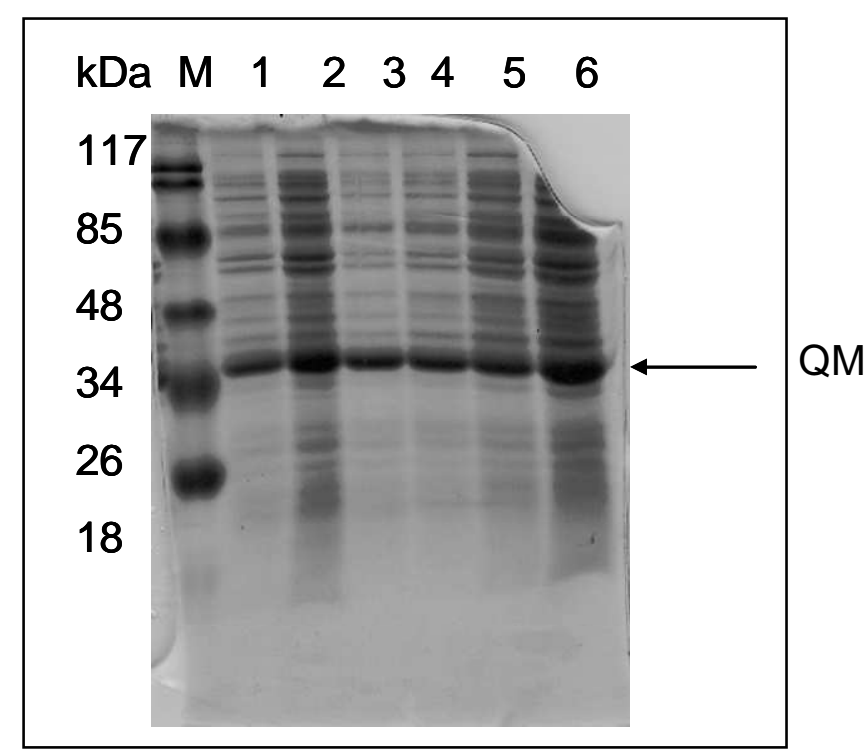

FIGURA 19: Expressão de QM em SDS-PAGE nas temperaturas de $25^{\circ} \mathrm{C}$ e $30^{\circ} \mathrm{C}$. M: marcador de massa molecular, colunas 1, 2 e 3, extrato cru, sp1 e sp2, respectivamente, de $Q M$ a 25. Colunas 4, 5 e 6, sp2, sp1 e extrato cru, respectivamente, de $Q M$ a $30^{\circ} \mathrm{C}$

Amostras caracterizadas como na FIG. 19, foram analisadas pelo método de varredura com quantificação por área pelo programa ImageJ. Os resultados obtidos em porcentagem de QM, sobre o total de bandas de proteína na coluna referente a cada etapa (EC, sp1 e sp2), foram utilizados na quantificação pelo método de Bradford. Por este método obteve-se a concentração em mg/mL de QM nas três etapas e estão descritos na TABELA 3. 
TABELA 3: Quantificação de QM pelo método de Bradford

\begin{tabular}{ccc}
\hline $\begin{array}{c}\text { Amostra de } \\
\text { QM }\end{array}$ & $\begin{array}{c}\text { Quantificação de proteína total na } \\
\text { amostra }(\mathrm{mg} / \mathrm{mL})\end{array}$ & $\begin{array}{c}\text { Quantificação de QM } \\
(\mathrm{mg} / \mathrm{mL})\end{array}$ \\
\hline $2^{\circ} \mathrm{C}$ EC & 5,2 & 1,4 \\
$25^{\circ} \mathrm{C}$ sp1 & 1,5 & 0,3 \\
$25^{\circ} \mathrm{C}$ sp2 & 0,6 & 0,2 \\
$30^{\circ} \mathrm{C}$ EC & 4,5 & 1,2 \\
$3^{\circ} \mathrm{C}$ sp1 & 1,6 & 0,3 \\
$3^{\circ} \mathrm{C}$ sp2 & 0,3 & 0,1 \\
\hline
\end{tabular}

Foi produzida em torno de $1,4 \mathrm{~g} / \mathrm{L}$ de proteína $\mathrm{QM}$ na amostra total do extrato cru em $25^{\circ} \mathrm{C}$ e um valor bem próximo em $30^{\circ} \mathrm{C} \quad(1,2 \mathrm{~g} / \mathrm{L})$, esse valor é quase 10 vezes maior que o da proteína produzida no periplasma, mesmo na amostra sp2 ainda há mais proteína QM do que no extrato cru da periplásmica, além disso, ela é obtida com menores níveis de contaminação.

Com a intenção de diminuir a quantidade de contaminantes presentes, foram introduzidas duas centrifugações após a retirada de QM solúvel da amostra, há perda de proteína nessas centrifugações, como já era esperado, mas ainda assim há uma recuperação de cerca de $20 \%$ de QM na primeira centrifugação e $25 \%$ na segunda (valores da proteína produzida a ${ }^{\circ} 5^{\circ} \mathrm{C}$ ) e esses valores em termos de $\mathrm{mg} / \mathrm{mL}$ ainda são satisfatórios.

Em termos de quantidade, a expressão de $\mathrm{QM}$ a $25^{\circ} \mathrm{C}$ é 1,15 vezes maior do que a expressa a $30^{\circ} \mathrm{C}(1,36 \mathrm{mg} / \mathrm{mL}$ e $1,19 \mathrm{~m} \mathrm{~g} / \mathrm{mL})$; o que não é uma diferença muito significativa. A recuperação em $25^{\circ} \mathrm{C}$ foi maior do que em $30^{\circ} \mathrm{C}$ (TAB. 4). 
TABELA 4: Recuperação de QM em porcentagem

\begin{tabular}{lll}
\hline Amostra & $\mathrm{sp} 1$ & $\mathrm{sp} 2$ \\
\hline $25^{\circ} \mathrm{C}$ & $21,4 \%$ & $25 \%$ \\
$30^{\circ} \mathrm{C}$ & $14,3 \%$ & $8 \%$ \\
\hline
\end{tabular}

A amostra de sp1 continha menor grau de impurezas e maior quantidade protéica, portanto, foi a utilizada nos ensaios de purificação.

\subsection{Purificação}

\subsubsection{Purificação de QM periplásmico}

A proteína $\mathrm{QM}$, por não ter sido recuperada no espaço periplásmico bacteriano, foi extraída de cultura ativada por lise celular por sonicação. Esta metodologia possibilitou a obtenção da proteína de interesse embora com muitas outras proteínas contaminantes.

A expressão de QM periplásmica produzida pelas bactérias transformadas com o vetor pET26_QM produziu uma proteína ligada a uma seqüência de 6 histidinas, sequência de aminoácidos que tem afinidade por metal, o que possibilitaria a utilização de resinas de afinidade por metais como Níquel ou Cobalto.

Inicialmente foram feitos algumas purificações com amostras de QM produzidas em bactérias e sonicadas em tris- $\mathrm{HCl} 20 \mathrm{mM} \mathrm{pH} \mathrm{7,5} \mathrm{em} \mathrm{resina} \mathrm{His-}$ Tag contendo íons Ni ou Co (FIG. 20). Essa purificação não foi eficiente, pois a proteína de interesse não se ligou à coluna, sendo eluída por completo durante a aplicação da amostra (flowthrough).

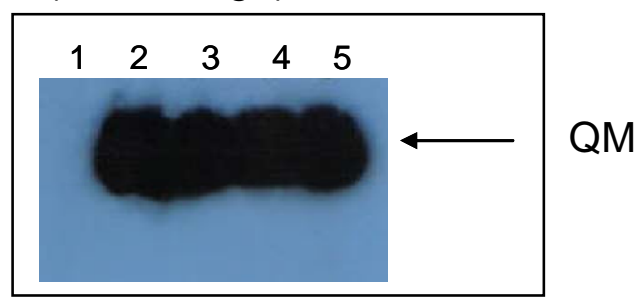

FIGURA 20: Análise da purificação com íons Ni e Co.

Coluna 1, marcador de massa molecular; coluna 2, amostra sonicada $150 \mathrm{~mL}$ de cultura de bactérias E.coli induzidas para expressão de QM em tris- $\mathrm{HCl} 20 \mathrm{mM}$ pH7,5 EDTA 10mM); coluna 3, amostra de sobrenadante de cultura ativada e 
sonicada após a diálise para retirada do EDTA; coluna 4, flowthrough da purificação em coluna His-Tag Ni; coluna 5, flowthrough da purificação em coluna His-Tag Co.

O fato de que o $\mathrm{pl}$ teórico da proteína QM tem seu valor em torno de 10, possibilita análises de purificação em diferentes tampões, portanto, foi utilizada uma estratégia de purificação de amostras, em resina de troca catiônica, com 4 diferentes tampões. As amostras foram sonicadas em tampões com pHs abaixo do pl da proteína QM, e os resultados de eluição encontram-se nas FIG. 21 e 22.

As purificações foram feitas em uma coluna de troca catiônica HiTrap SP XL (GE). A eluição de QM foi obtida com $250 \mathrm{mM}$ de $\mathrm{NaCl}$ em tampão tris- $\mathrm{HCl}$ $20 \mathrm{mM} \mathrm{pH} \mathrm{7,5,} \mathrm{houve} \mathrm{perda} \mathrm{de} \mathrm{QM} \mathrm{que} \mathrm{saiu} \mathrm{com} \mathrm{as} \mathrm{proteínas} \mathrm{não} \mathrm{retidas,} \mathrm{o} \mathrm{que}$ sugeriu uma otimização do ensaio. Portanto, foram feitas mais três purificações alterando-se o pH do tampão onde a amostra foi sonicada.

Na FIG. 21 está representada uma análise em Western blotting de etapas de purificação em dois tampões diferentes, trisHCl pH 7,5 e bicina pH 8,3.

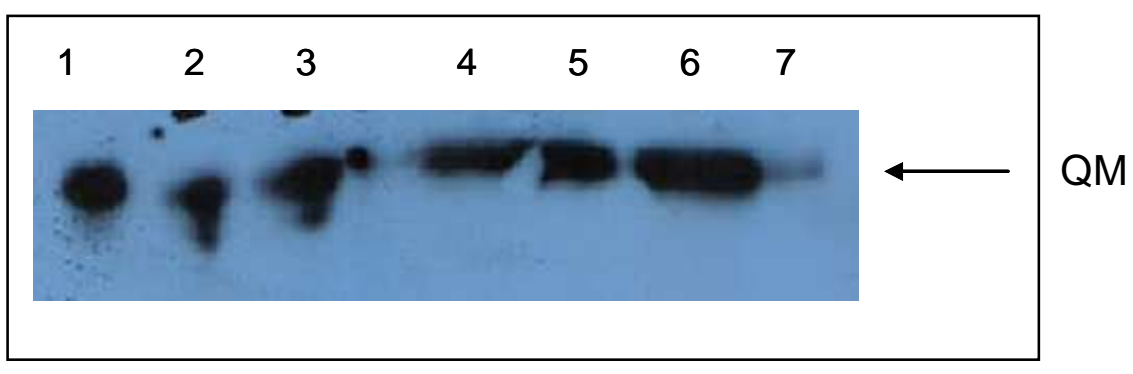

FIGURA 21: Western blotting do ensaio de purificação em troca catiônica, coluna HiTrap SP XL.

Coluna 1, cultura ativada; coluna 2, cultura ativada com extração da poteína QM por sonicação em tris- $\mathrm{HCl} 20 \mathrm{mM} \mathrm{pH} \mathrm{7,5;} \mathrm{coluna} \mathrm{3,} \mathrm{flowthrough} \mathrm{da} \mathrm{purificação} \mathrm{em}$ coluna HiTrap SP XL (tris-HCl); coluna 4, eluição com tris- $\mathrm{HCl} 250 \mathrm{mM} \mathrm{NaCl}$; coluna 5, cultura ativada com extração da proteína QM por sonicação em tampão Bicine 50mM pH 8,33; coluna 6, flowthrough da purificação HiTrap SP XL (Bicine); coluna 7, eluição com Bicine $250 \mathrm{mM} \mathrm{NaCl}$.

Outra cromatografia de troca catiônica em coluna HiTrap SP XL foi feita com tampão fosfato de sódio $50 \mathrm{mM} \mathrm{pH} \mathrm{7,2.}$ 
Uma amostra foi sonicada em fosfato de sódio $50 \mathrm{mM} \mathrm{pH} \mathrm{7,2} \mathrm{e} \mathrm{uma}$

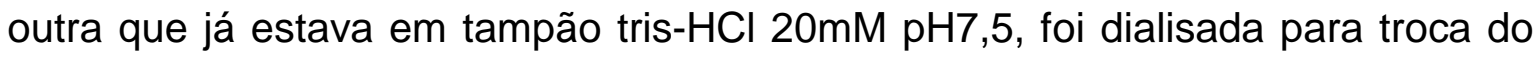
tampão por fosfato. A diálise foi feita em saquinho de diálise de poro $14 \mathrm{kDa}$ e as amostras foram dialisadas contra $2 \mathrm{~L}$ de solução de fosfato de sódio $50 \mathrm{mM} \mathrm{pH} \mathrm{7,2}$ com agitação lenta a $7^{\circ} \mathrm{C}$. A solução tampão foi trocada por três vezes.

Na FIG. 22, é possível observar que há uma perda de QM na diálise pela presença de QM na coluna 4, que é o precipitado formado após a amostra ter sido dialisada. A partir desse ensaio, não foi feita nenhuma diálise para não haver perda de proteína. Além disso, a purificação em tampão fosfato não foi eficiente, sendo detectada a presença de QM na amostra que passou pela coluna (coluna 3).

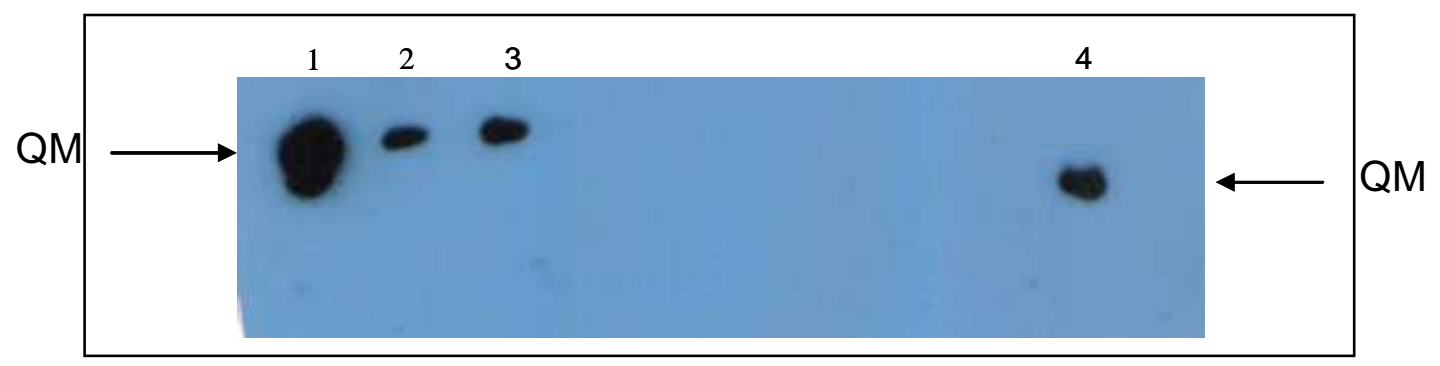

FIGURA 22: Cromatografia de troca catiônica em coluna HiTrap SP XL em tampão Fosfato de Sódio 50mM pH 7,2.

Coluna 1, amostra sonicada em Fosfato de Sódio $50 \mathrm{mM} \mathrm{pH} \mathrm{7,2;} \mathrm{coluna} \mathrm{2,}$ amostra após a diálise; coluna 3, amostra após passar pela coluna da Purificação em coluna HiTrap SP XL; coluna 4, QM precipitado após diálise.

\subsubsection{Purificação de QM citoplásmico}

A purificação de QM citoplásmico, fração sp1, foi exclusivamente por cromatografia de exclusão molecular, isso porque a amostra era produzida com bem pouco contaminante e em quantidades suficientes para este tipo de separação (FIG 25, colunas 2, 3 e 4). Como dito anteriormente, utilizamos as duas temperaturas escolhidas $25^{\circ} \mathrm{C}$ e $30^{\circ} \mathrm{C}$. Nessa pur ificação, foi adicionado à amostra uma concentração de $150 \mathrm{mM}$ de $\mathrm{NaCl}$, este procedimento permite que a amostra seja eluída em picos melhor definidos. A purificação foi realizada numa coluna Sepharose 200, com coletas de $0,5 \mathrm{~mL}$ por tubo, num fluxo de $1 \mathrm{~mL}$ / 
minuto e, de acordo com ensaios anteriores, os 20 primeiros tubos, $10 \mathrm{~mL}$, foram descartados.

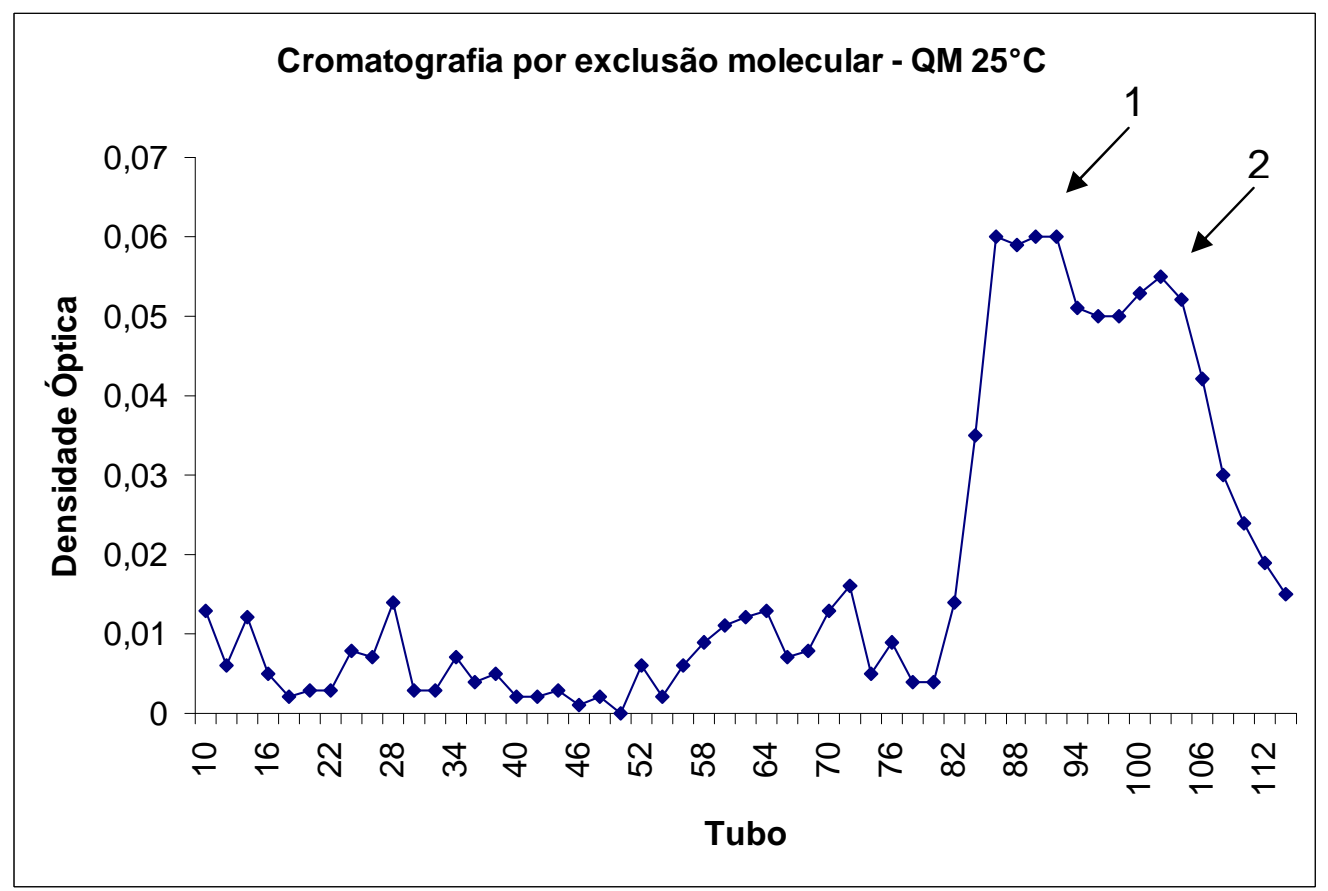

FIGURA 23: Perfil da cromatografia por exclusão molecular com amostras da ativação a $25^{\circ} \mathrm{C}$.

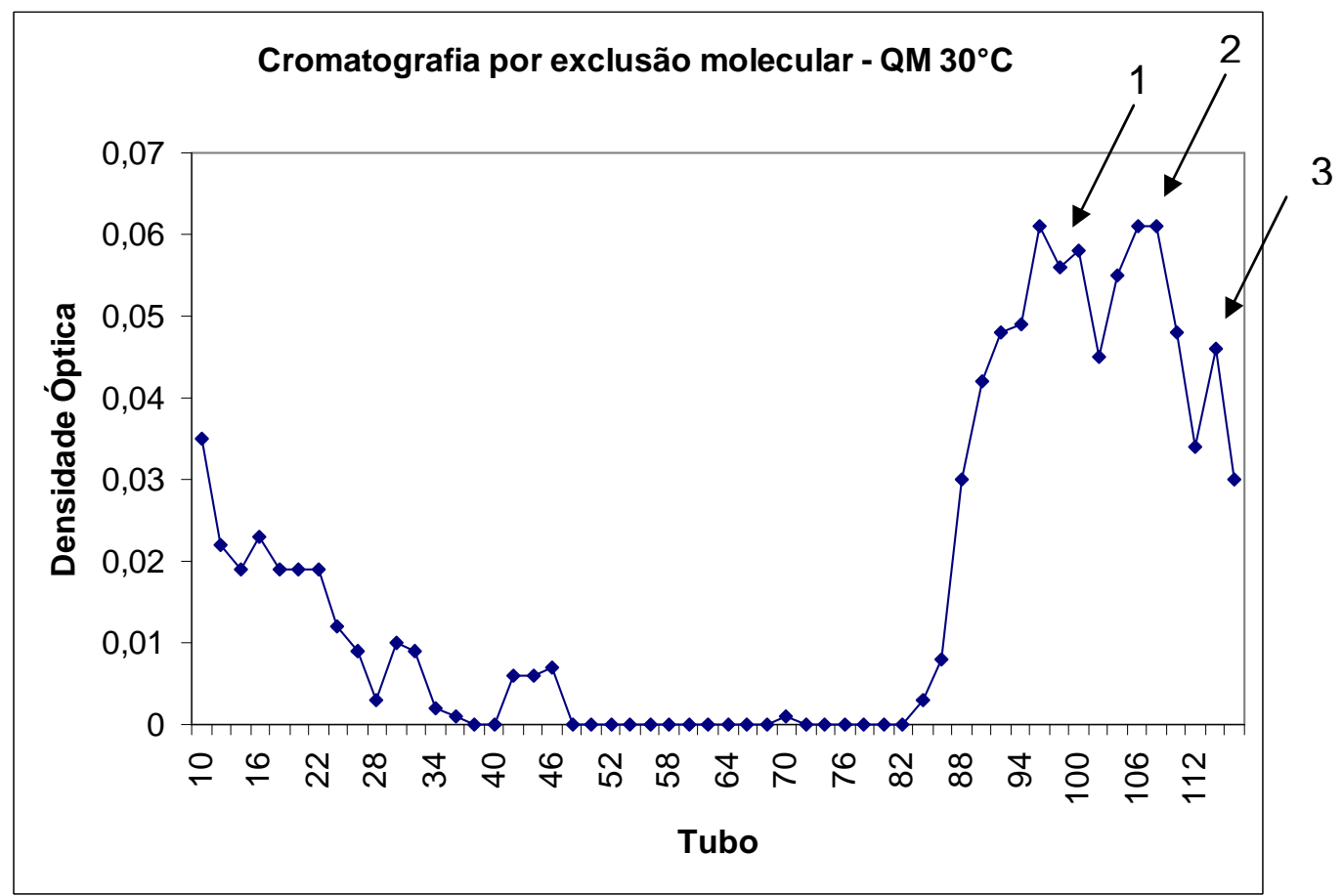

FIGURA 24: Perfil da cromatografia por exclusão molecular com amostras da ativação a $30^{\circ} \mathrm{C}$. 
Pode-se notar que, tanto na amostra produzida a $25^{\circ} \mathrm{C}$ quanto a produzida a $30^{\circ} \mathrm{C}$, a proteína saiu no final da corri da, em ambos os casos, por volta do tubo 82, este resultado é esperado, já que o massa molecular dela que é em torno de $25 \mathrm{kDa}$.

Uma avaliação dos resultados obtidos nas purificações em cromatografia de exclusão molecular encontra-se na FIG. 25.

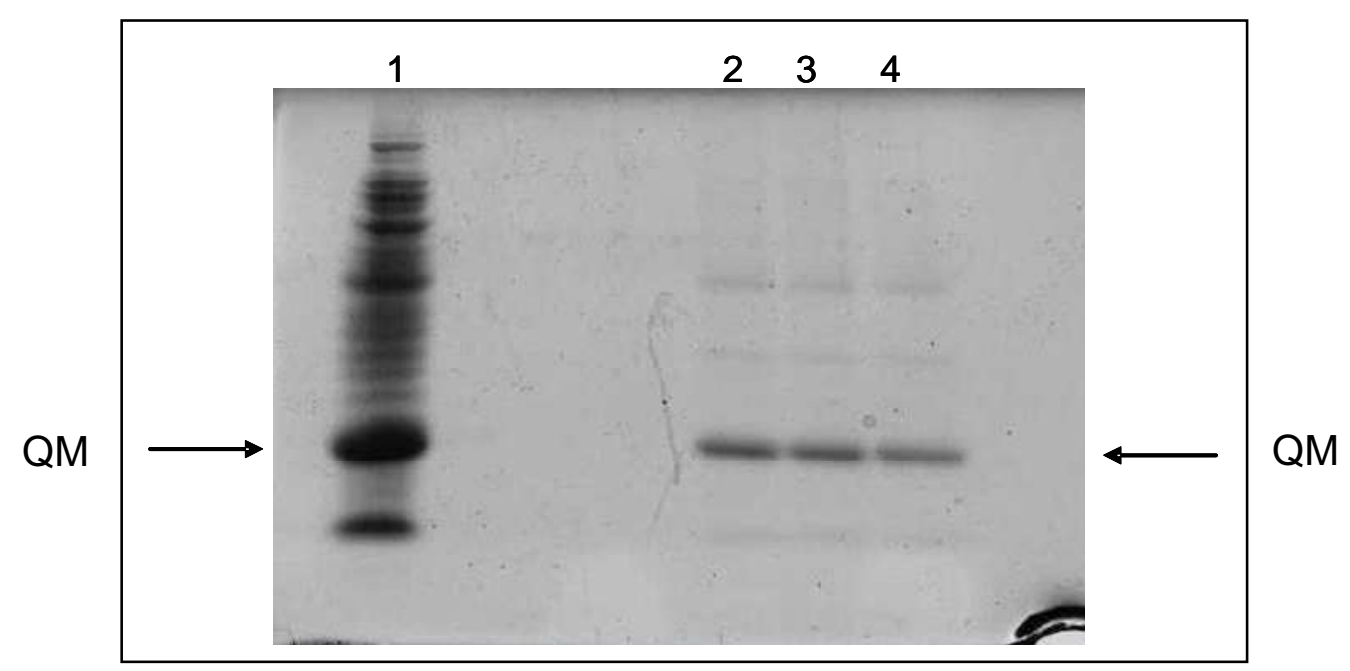

FIGURA 25: Cromatografia por Exclusão Molécula em SDS-PAGE. Coluna 1, amostra antes de passar na coluna, colunas 2, 3 e 4 picos.

A amostra saiu quase sem contaminantes e, para prosseguir com os ensaios de estrutura, foi feita uma diálise para a retirada do sal da amostra, mesmo sendo em pequena concentração, esse sal interferiu no ensaio de CD, aumentando um pouco a voltagem e dificultando as análises.

\subsection{Caracterização estrutural por Dicroísmo Circular}

A integridade estrutural das proteínas foi avaliada por dicroísmo circular.

Tendo em vista os resultados de purificação que não possibilitaram a obtenção da proteína QM periplásmica pura, a caracterização de QM por Dicroísmo Circular foi feita somente com a amostra de proteína solúvel expressa 
pelo vetor p1813_QM. De início foi utilizada uma amostra purificada por exclusão molecular, a mesma amostra observada na FIG. 25, colunas 2, 3 e 4.

As amostras após sonicação e centrifugação e a que foi eluída da coluna de exclusão molecular com $150 \mathrm{mM}$ de $\mathrm{NaCl}$ foram analisadas por dicroísmo circular. Esta amostra por conter $150 \mathrm{mM} \mathrm{NaCl}$ não produziu um espectro com boa resolução, então foi dialisada para a retirada do sal, o que não resolveu o problema pois o novo resultado obtido não apresentou conformação $\alpha$ hélice nem tampouco de folha $\beta$ (dados não mostrados).

As amostras sp2 de ambas as temperaturas, $2^{\circ} \mathrm{C}$ e $30^{\circ} \mathrm{C}$, analisadas em SDS-PAGE, continham pouquíssimos contaminantes, e possuíam a concentração necessária para fazer os ensaios de CD, portanto foram utilizadas.

Os dados obtidos por CD foram analisados pelo programa CDNN, como descrito em Metodologias.

Nas FIG. 26 e 27 estão representados os espectros gerados pelo programa CDNN, amostras obtidas nas temperaturas de ativação de $25^{\circ} \mathrm{C}$ e $3^{\circ} \mathrm{C}$. Ambas apresentam um perfil muito parecido, co nfigurando uma estrutura em $\alpha$-hélice.

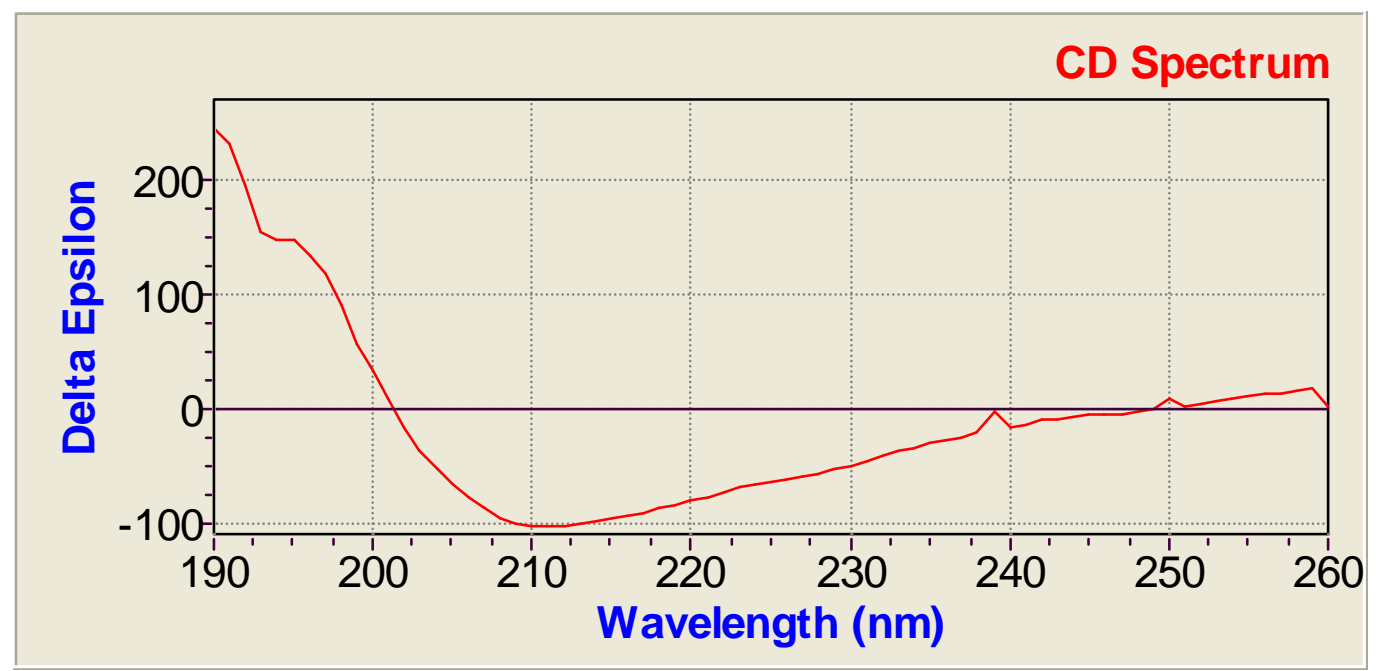

FIGURA 26: Perfil de CD da amostra de QM sp2 expressa a $25^{\circ}$. 


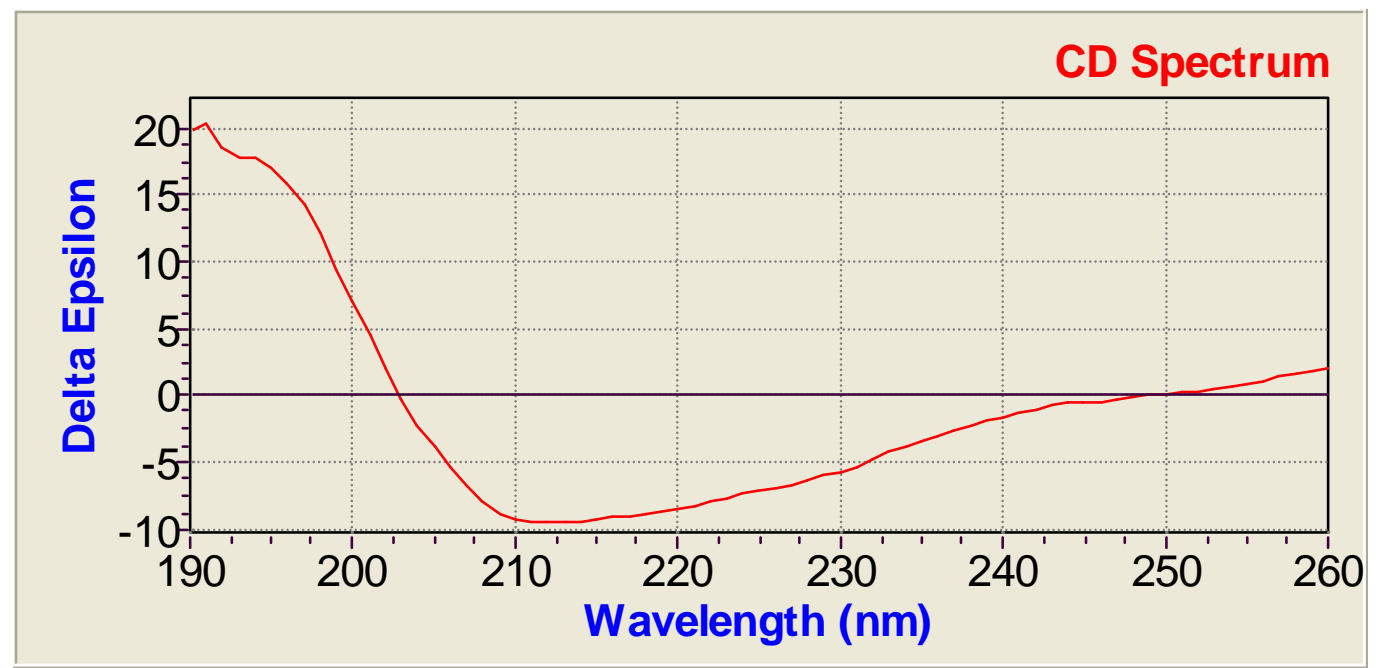

FIGURA 27: Perfil de CD da amostra de QM sp2 expressa a 30C.

Após esse ensaio de identificação do perfil de CD das amostras, foi feita uma avaliação da ação do reagente Guanidina em concentrações crescentes. Foram sete concentrações, 0 M, 10 mM, 25 mM, 50 mM, 75 mM, 100 $\mathrm{mM}, 500 \mathrm{mM}$ e $1 \mathrm{M}$.

A guanidina faz com que a proteína perca sua conformação, mas também possui absorbância na faixa de leitura para $C D$, o que interferia nos espectros gerados. Em vista disso, foi feito um branco para cada concentração de guanidina utilizada e este foi subtraído das amostras.

A interferência da guanidina na leitura pode ser verificada no item porcentagem total das TABELAS 5 e 6 . Os valores de $\alpha$-hélice foram decrescendo gradativamente com o acréscimo da guanidina. Porcentagem total significa a confiança do intervalo de comprimento de onda escolhido para as análises. Quanto mais próximo dos $100 \%$, mais confiável são os dados do espectro gerado. Neste trabalho, foi escolhido o intervalo de comprimentos de $\lambda 190$ a $260 \mathrm{~nm}$, isso porque foi o maior intervalo obtido e a porcentagem ainda era bastante próxima dos 100 , demonstrando maior confiabilidade para os mesmos.

As FIG. 28 e 29 correspondem aos perfis obtidos com as diferentes concentrações de guanidina nas amostras de $25^{\circ} \mathrm{C}$ e $30^{\circ} \mathrm{C}$, respectivamente. É possível perceber que a proteína em questão é predominantemente composta por $\alpha$-hélice e, com o acréscimo da guanidina, a proteína vai perdendo sua 
conformação, com isso, perdendo a $\alpha$-hélice e passando a ter um perfil de folhas $\beta$.

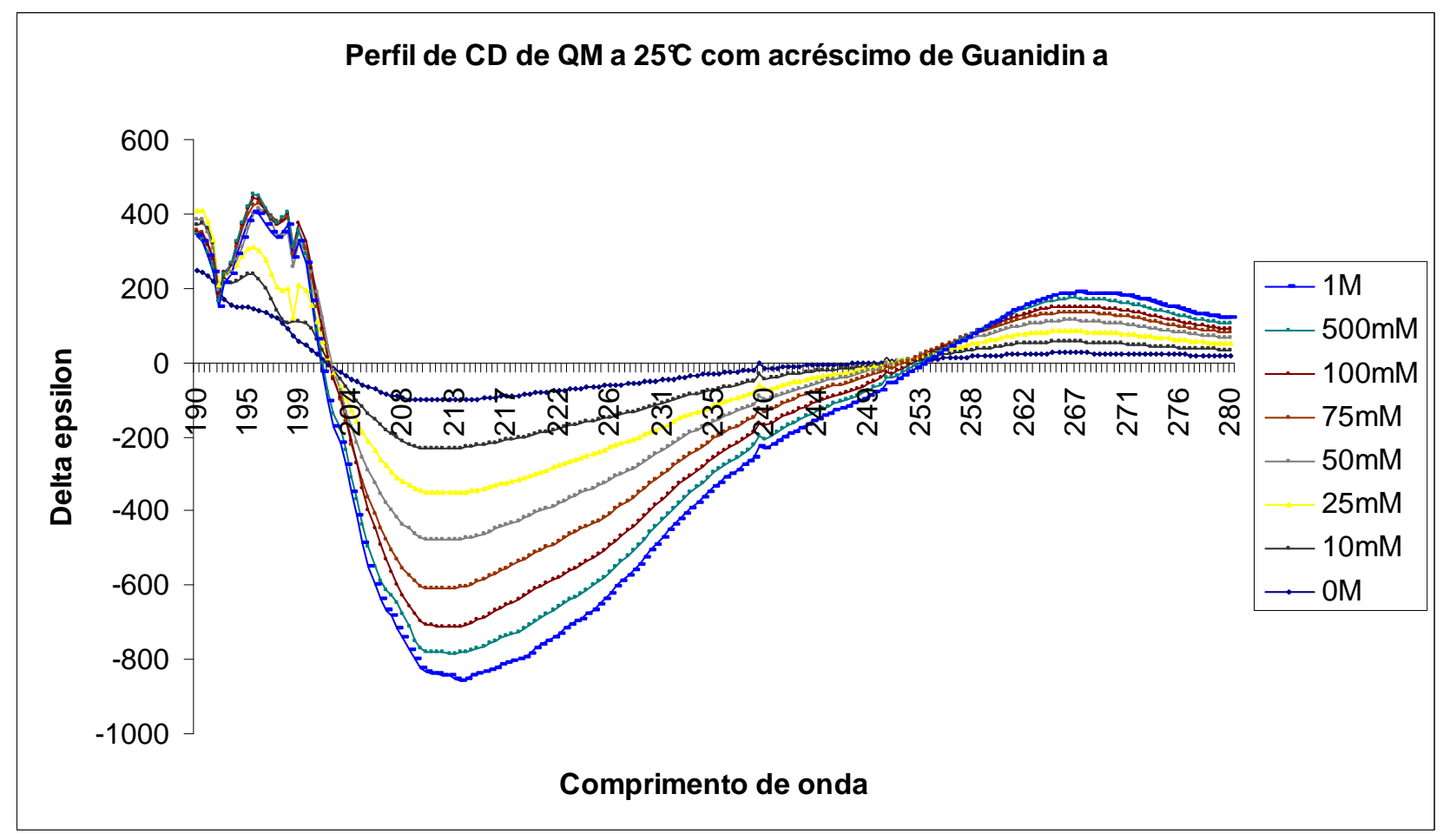

FIGURA 28: Perfil de estrutura secundária de QM citoplásmico expresso a $25 C$ por Dicroísmo Circular com acréscimo de guanidina.

$\mathrm{Na}$ legenda estão as diferentes concentrações de guanidina que foram adicionadas á amostra. 


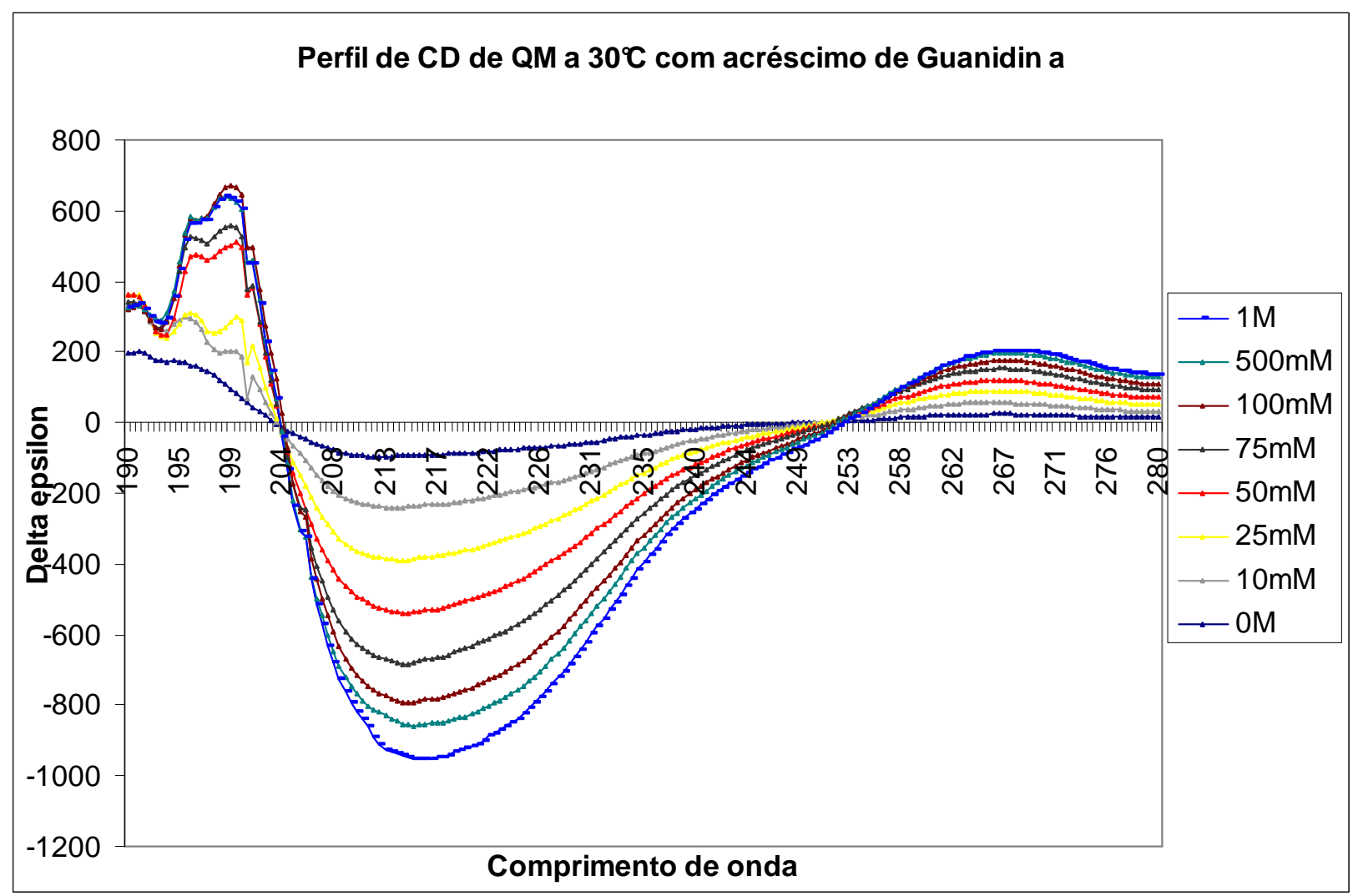

FIGURA 29: Perfil de estrutura secundária de QM citoplásmico expresso a 30 C por Dicroísmo Circular com acréscimo de guanidina.

$\mathrm{Na}$ legenda estão as diferentes concentrações de guanidina que foram adicionadas á amostra.

Os dados obtidos por CD, das amostras produzidas nas temperaturas de $25^{\circ} \mathrm{C}$ e $30^{\circ} \mathrm{C}$, foram analisados pelo programa CDNN e estão sumarizados nas TABELAS 5 e 6, respectivamente. Nas duas condições de temperatura o padrão de desenovelamento da proteína foi semelhante. Nas duas amostras, com o aumento da concentração de guanidina, a proteína saiu de uma conformação de $\alpha$-hélice para uma folha $\beta$ e por fim parcialmente sem conformação. 
TABELA 5: Modificações na estrutura secundária de QM com acréscimo de guanidina em amostra de QM sp2 expressa a $25^{\circ} \mathrm{C}$

\begin{tabular}{ccccccc}
\hline $\begin{array}{c}\text { Concentração de } \\
\text { Guanidina }\end{array}$ & $\mathbf{0 ~ M}$ & $\mathbf{1 0} \mathbf{~ m M}$ & $\mathbf{2 5} \mathbf{~ m M}$ & $\mathbf{5 0} \mathbf{~ m M}$ & $\mathbf{7 5} \mathbf{~ m M}$ & $\mathbf{1 0 0} \mathbf{~ m M}$ \\
\hline Helix & $99,70 \%$ & $80,20 \%$ & $76,20 \%$ & $79 \%$ & $69,40 \%$ & $50,90 \%$ \\
Antiparallel & $0,00 \%$ & $0,30 \%$ & $0,40 \%$ & $0,20 \%$ & $1,10 \%$ & $2,10 \%$ \\
Parallel & $0,10 \%$ & $1,80 \%$ & $2,40 \%$ & $2,30 \%$ & $2,40 \%$ & $5,30 \%$ \\
Beta-turn & $3,10 \%$ & $10,20 \%$ & $11 \%$ & $10,60 \%$ & $12,70 \%$ & $13,70 \%$ \\
Rndm-Coil & $0,30 \%$ & $5,10 \%$ & $7,30 \%$ & $7,30 \%$ & $6,50 \%$ & $20,50 \%$ \\
$\begin{array}{c}\text { Porcentagem } \\
\text { total }\end{array}$ & $103,30 \%$ & $97,60 \%$ & $97,20 \%$ & $97,20 \%$ & $92,20 \%$ & $92,60 \%$ \\
\hline
\end{tabular}

TABELA 6: Modificações na estrutura secundária de QM com acréscimo de guanidina em amostra de QM sp2 expressa a $30^{\circ} \mathrm{C}$

\begin{tabular}{ccccccc}
\hline $\begin{array}{c}\text { Concentração de } \\
\text { Guanidina }\end{array}$ & $\mathbf{0 ~ M}$ & $\mathbf{1 0} \mathbf{~ m M}$ & $\mathbf{2 5} \mathbf{~ m M}$ & $\mathbf{5 0} \mathbf{~ m M}$ & $\mathbf{7 5} \mathbf{~ m M}$ & $\mathbf{1 0 0} \mathbf{~ m M}$ \\
\hline Helix & $86,70 \%$ & $89,10 \%$ & $74,20 \%$ & $87,50 \%$ & $75,30 \%$ & $58,30 \%$ \\
Antiparallel & $0,00 \%$ & $0,00 \%$ & $0,30 \%$ & $0,00 \%$ & $0,30 \%$ & $0,40 \%$ \\
Parallel & $1,80 \%$ & $1,40 \%$ & $2,80 \%$ & $2,10 \%$ & $2,60 \%$ & $6,50 \%$ \\
Beta-turn & $8,10 \%$ & $7,60 \%$ & $10,40 \%$ & $7,70 \%$ & $10,50 \%$ & $11,20 \%$ \\
Rndm-Coil & $6,40 \%$ & $4,80 \%$ & $10,10 \%$ & $9 \%$ & $8,90 \%$ & $32,70 \%$ \\
$\begin{array}{c}\text { Porcentagem } \\
\text { total }\end{array}$ & $103 \%$ & $103 \%$ & $97,80 \%$ & $106,3 \%$ & $97,60 \%$ & $109,1 \%$ \\
& & & & & & \\
\end{tabular}


É possível notar que a amostra produzida na temperatura de $25^{\circ} \mathrm{C}$ possui maior porcentagem de $\alpha$-hélice, $99,7 \%$, quando comparada à de $30^{\circ} \mathrm{C}$, $86,7 \%$. Outro ponto a ser observado é o gradativo e linear decaimento da porcentagem de $\alpha$-hélice e concomitante aumento de folhas $\beta$ observado notadamente na amostra de $25^{\circ} \mathrm{C}$. Este fato não é obs ervado com a amostra de $30^{\circ} \mathrm{C}$ e não há uma correlação entre as diminuições e aumentos das porcentagens de $\alpha$-hélice com as porcentagens de folha $\beta$. É o caso observado nas concentrações de guanidina de 25, 50 e 75 mM, as porcentagens encontradas para $\alpha$-hélice são $74,2 \%, 87,5 \%$ e $75,3 \%$, respectivamente, e para folha $\beta$ permanecem em torno de $13 \%$ (13,5\%, 13,1\% e 13,4\%).

Analisando os resultados iniciais e finais temos que a amostra de $25^{\circ} \mathrm{C}$ iniciou com $99,7 \%$ de $\alpha$-hélice e com $1 \mathrm{M}$ de guanidina passou para $32,1 \%$, uma perda considerável $(67,6 \%)$, um o aumento de folhas $\beta(37,7 \%)$ e o aumento de formas randômicas $22,8 \%$.

No caso da amostra de $30^{\circ} \mathrm{C}$, esta iniciou com $86,7 \%$ de $\alpha$-hélice e com $1 \mathrm{M}$ de guanidina passou para $36,3 \%$, teve uma perda de $50,4 \%$, enquanto que a o aumento de folhas $\beta$ foi de $19,4 \%$, bem inferior ao obtido no caso anterior, e o aumento de formas randômicas foi da mesma ordem $25,5 \%$. 


\subsection{Caracterização de QM por emissão de fluorescência}

A estrutura terciária da proteína foi analisada por emissão de fluorescência do aminoácido triptofano.

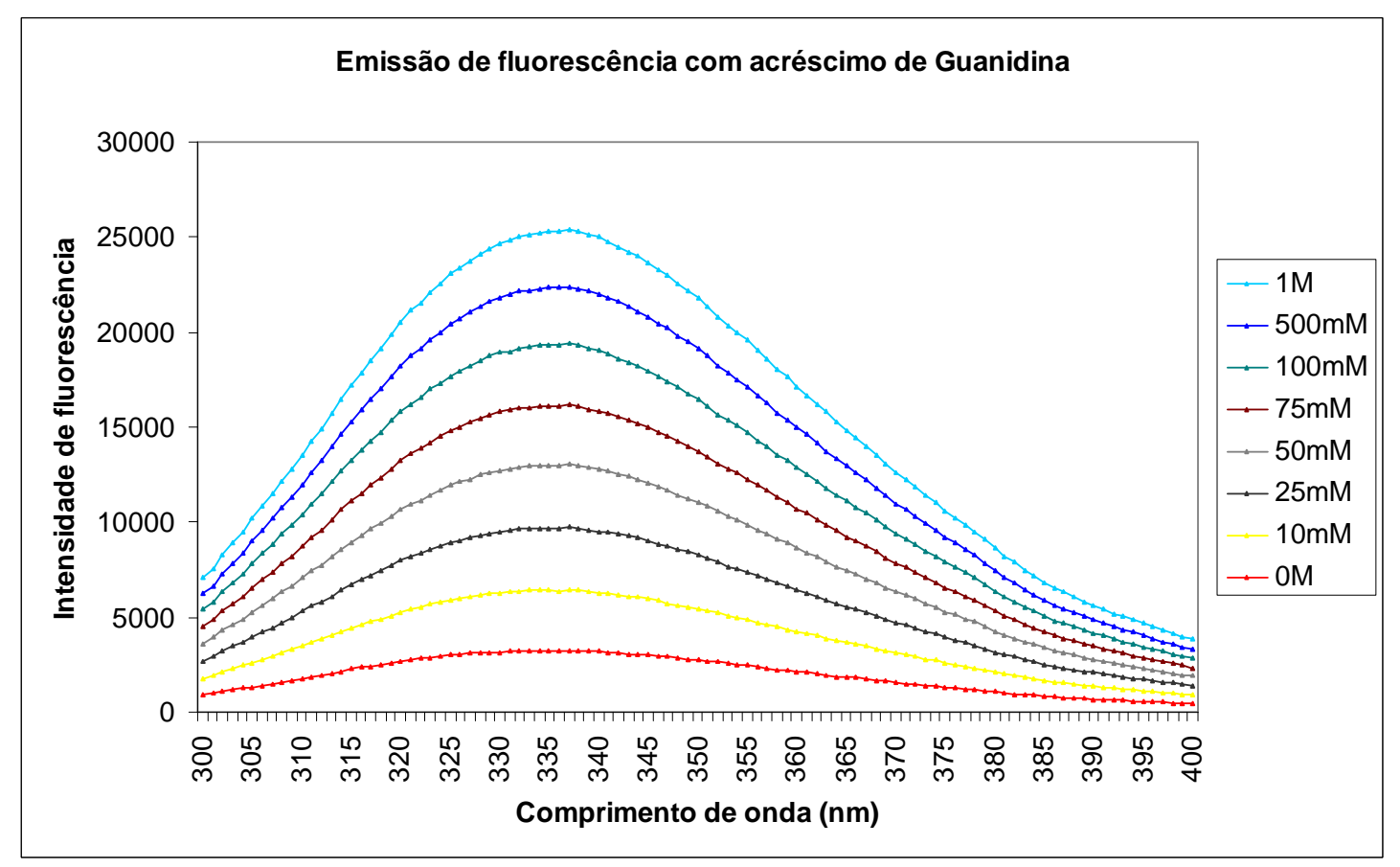

FIGURA 30: Curva da emissão de fluorescência do triptofano da amostra de QM citoplásmica ativada a $25^{\circ} \mathrm{C}$ com desnaturação da pro teína por Guanidina. 


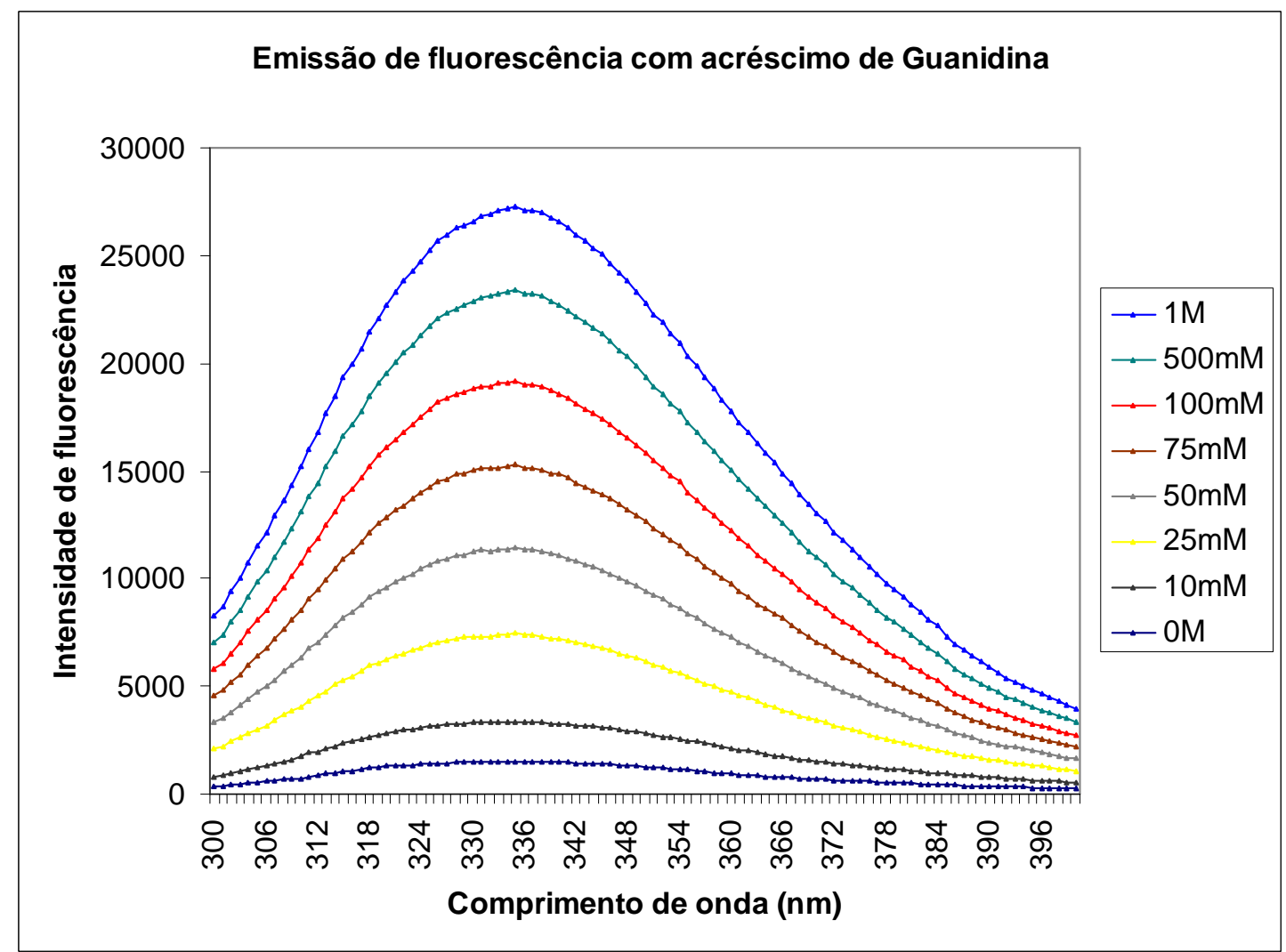

FIGURA 31: Curva da emissão de fluorescência do triptofano da amostra de QM citoplásmica ativada a $25^{\circ} \mathrm{C}$ com desnaturação da pro teína por Guanidina.

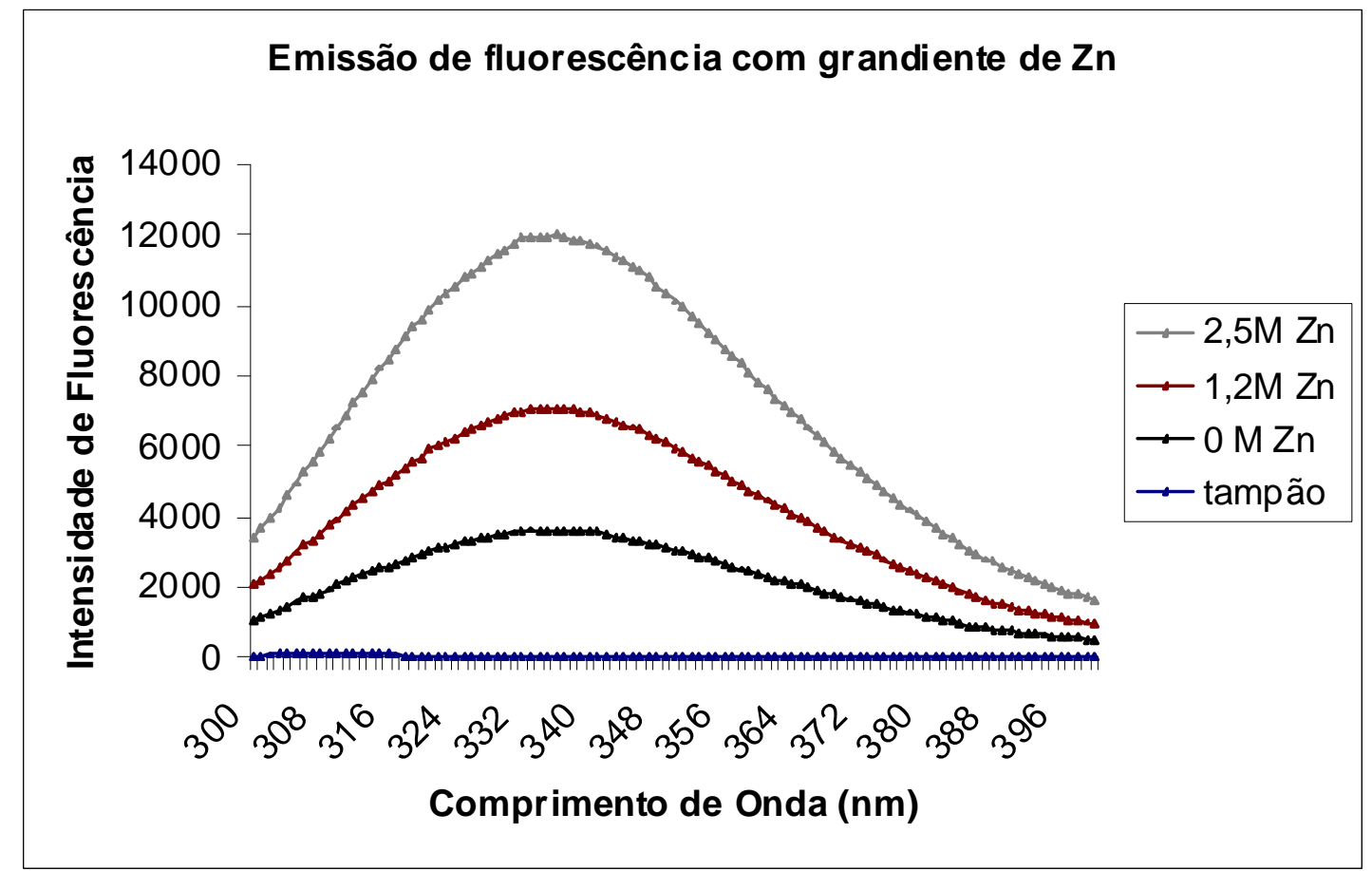

FIGURA 32: Curva da emissão de fluorescência do triptofano da amostra de QM citoplásmica ativada a $25^{\circ} \mathrm{C}$ com acréscimo de zinco. 


\section{DISCUSSÃO}

Diante da gravidade e do aumento do número de pessoas com câncer, muitos grupos de pesquisa vem trabalhando no sentindo de desenvolver marcadores moleculares que ajudem no diagnóstico correto da doença bem como, auxiliem no tratamento da mesma. A disponibilização do genoma possibilitou o estudo de um grande número de genes envolvidos em tumores. Este fato acoplado a técnica do DNA recombinante aumentou consideravelmente a produção de proteínas e peptídeos com potencial terapêutico e diagnóstico.

Algumas proteínas ribossomais, por terem múltiplas funções na célula, tem sido alvo de estudos, particularmente a proteína ribossomal L10 (QM ou RP L10) que possui ação supressora de tumor. Fato esse que a torna um alvo interessante para o desenvolvimento de marcadores e/ou bloqueadores que auxiliem na detecção e/ou parada do crescimento tumoral.

A expressão desta, bem como de inúmeras proteínas de eucariotos, pode ser feita em sistemas heterólogos. Onde o sistema que é escolhido preferencialmente é o da bactéria Escherichia coli, devido ao alto nível de proteína recombinante produzida, rapidez e baixo custo.

Neste trabalho foi avaliada a influência de alguns fatores intrínsecos e extrínsecos que afetam a expressão da proteína QM recombinante produzida em sistema bacteriano. A expressão da proteína recombinante QM no espaço periplásmico da bactéria foi comparada à expressão no citoplasma. Foram estabelecidas as condições de obtenção de QM na sua conformação estrutural resultante da expressão citoplásmica da proteína em bactérias.

Na primeira parte do trabalho, com o intuito de aumentar a eficiência de expressão no periplasma bacteriano, optou-se por fazer uma clonagem no vetor p3SN8 que possui uma alta eficiência de expressão de proteínas recombinantes. Dados da literatura indicam uma produção de 0,7 $\mu \mathrm{g} / \mathrm{mL}$ (Morganti e cols., 1996) e 0,25 $\mu \mathrm{g} / \mathrm{mL}$ (Grahan, 1995); e para a proteína QM não houve expressão. 
A expressão de QM já vinha sendo feita com as bactérias transformadas com o vetor pET26b_QM, porém em quantidades insuficientes para os testes finais de estrutura. Nas condições estabelecidas neste trabalho, com otimização do tempo de cultivo e concentração de IPTG utilizada, não foi obtida expressão de QM pelo vetor p3SN8_QM, mas foi conseguida pelo pET26b_QM. As condições de cultivo que propiciaram esta expressão foram: (i) a adição de 0,5 mM de IPTG para a ativação do promotor e consequente expressão da proteína QM e (ii) cultivo a 30 por 16 horas.

A redução da temperatura de ativação da cultura bacteriana é muito utilizada para expressão de proteínas que agregam ou que são de difícil expressão (Makrides, 1996 e Sorensen e cols., 2005) e neste trabalho, a queda da temperatura, foi um fator determinante para a expressão. Estas condições de cultivo, também foram aplicadas às bactérias transformadas com o vetor p3SN8 sem nenhum resultado positivo.

Neste trabalho, a produção de QM foi de $0,13 \mathrm{mg} / \mathrm{mL}$ com a cultura transformada com o vetor pET26b_QM, esta produção foi muito acima do esperado, principalmente se for comparada com a expressão pelo vetor p3SN8 descrita na literatura. A porcentagem esperada para a expressão de proteína recombinante periplásmica sobre o total de proteínas bacteriana é de $4 \%$ (Makrides, 1996), neste trabalho foi conseguida 6,8\%, aqui também uma taxa superior aos dados da literatura.

Definidos os protocolos de ativação e expressão da proteína QM recombinante, a etapa seguinte foi aperfeiçoar a extração da proteína no espaço periplásmico e para isso foram testados alguns protocolos de choque osmótico. Os protocolos utilizados contemplavam desde a obtenção da proteína de interesse em grandes volumes $(5 \mathrm{~mL})$ até em microlitros, partindo dos mesmos volumes de cultura ativada. Da avaliação dos resultados obtidos foi possível observar que na etapa de adição de glicose, há uma interação entre bactéria e meio (solução com glicose) que pode ser de importância vital na retirada da água de dentro da bactéria, provocando assim uma eficiente saída das proteínas para o periplasma. $\mathrm{Na}$ segunda etapa do choque, há um aumento do turgor da membrana pela entrada da solução de $\mathrm{MgCl}_{2}$ ou água, forçando as proteínas do periplasma saírem para o meio extracelular. 
Quando comparados os resultados dos choques com redução de volume da solução de $\mathrm{MgCl}_{2}$ (FIG 10, colunas 3 e 4), só o protocolo que manteve o volume original de solução de glicose é que possibilitou uma maior recuperação da proteína QM. Mesmo com uma melhor eficiência, a quantidade de proteína de interesse extraída com o choque osmótico se mostrou muito baixa quando comparada com a produzida pela bactéria. Neste ponto foi testada a adição da enzima lisozima com o intuito de aumentar a permeabilidade da parede bacteriana a fim de promover um aumento na saída das proteínas do periplasma (Rathore e cols., 2003). A ação da enzima lisozima, em baixas concentrações, provoca um quebra na parede bacteriana, formando "poros" que possibilitam a saída das proteínas do espaço periplásmico para o exterior. Esta ação da lisozima é facilitada pela adição de EDTA, este composto permite a quebra dos lipopolissacarídeos da parte externa da parede bacteriana, permitindo uma desestruturação da parede e consequente ação da lisozima (Bayer e cols., 1977, Rathore e cols., 2003). Mesmo assim não houve melhora na eficiência da saída da proteína para o meio externo.

Embora se tenham testados alguns protocolos de choques osmóticos, esta técnica teve uma recuperação muito aquém do que a bactéria realmente produziu. São muitos os fatores que interferem na passagem da proteína para o periplasma, o mais evidente é a seqüência sinalizadora utilizada. Os vetores utilizados, pET26b e p3SN8, possuem sequências sinalizadoras de comprovada eficiência no transporte para o periplasma, sendo referenciada por Sorensen $e$ cols. (2005) e Morganti e cols (1996), respectivamente. O observado para a proteína QM é que esta foi expressa em quantidades satisfatórias, a seqüência sinalizadora era adequada e foram testados vários protocolos de choque osmótico sem sucesso. Em vista disso pode-se supor que haja impedimentos pertinentes a própria constituição da proteína que a impeçam de ser transportada para o periplasma, pode ser sua composição específica de aminoácidos ou o seu possível enovelamento.

Uma alternativa para a obtenção da proteína QM solúvel foi utilizar a técnica de lise celular por sonicação. Este procedimento se mostrou muito mais eficiente, porém a amostra ainda continha uma quantidade muito alta de proteínas bacterianas contaminantes. Para tentar solucionar esse problema, esta amostra, sobrenadante de cultura sonicada, foi submetida a uma ultracentrifugação, o que 
possibilitou uma redução dos contaminantes. Higgins \& Barrnett (1972) utilizaram esta técnica para o isolamento de retículo endoplasmático liso e rugoso dos outros componentes celulares com sucesso. Porém, a redução dos contaminantes bacterianos se estendeu também à redução da proteína $Q M$, levando à precipitação da mesma, o que não era de interesse. Portanto, se o tempo e a velocidade da ultracentrifugação fossem alterados, o resultado poderia não ser satisfatório, pois as impurezas continuariam presentes. Embora as análises por Western blotting indicassem uma diferença bastante expressiva nas quantidades de proteína obtidas no choque e na sonicação, é importante lembrar que este ensaio não é adequado para quantificação.

Em relação à proteína $\mathrm{QM}$ expressa no citoplasma, esta teve uma alta expressão na forma agregada, o que já era esperado. A quantidade de proteína foi de aproximadamente $1 \mathrm{mg} / \mathrm{mL}$ na cultura bacteriana ativada (Silva, e cols 2008).

Vera e cols. (2007), estudando a proteína fluorescente GFP (Green Fluorescent Protein) expressa na forma agregada, encontraram uma relação bastante interessante entre os efeitos da temperatura de ativação e a conformação estrutural. A diminuição da temperatura de ativação permitiu a obtenção da proteína GFP na forma solúvel e com o enovelamento correto.

Neste trabalho foram encontrados resultados parecidos de expressão de QM nas temperaturas de $25^{\circ} \mathrm{C}$ e $30^{\circ} \mathrm{C}$. Nos cultivos em $18^{\circ} \mathrm{C}, 2^{\circ} \mathrm{C}$ e $30^{\circ} \mathrm{C}$ houve a expressão de proteína solúvel juntamente com proteína agregada, enquanto que nas temperaturas de cultivo de $3^{\circ} \mathrm{C}$ e $4^{\circ} \mathrm{C}$ só houve a obtenção de proteína agregada. A quantidade obtida foi de $1,4 \mathrm{mg} / \mathrm{mL}$ na temperatura de $25^{\circ} \mathrm{C}$ e de $1,2 \mathrm{mg} / \mathrm{mL}$ a $30^{\circ} \mathrm{C}$, aproximadamente 10 veze $\mathrm{s}$ mais que a produzida no priplasma. $\mathrm{Na}$ literatura há dados de produção de proteína recombinante agregada no citoplasma em uma porcentagem de $50 \%$ sobre o total de proteínas bacterianas (Makrides, 1996), neste trabalho foi conseguida 26\% de QM.

A obtenção de proteína QM na forma solúvel se deve ao fato de que em baixas temperaturas a proteína é expressa em quantidades menores ao longo do tempo, o que colabora com o enovelamento, além do que a energia livre do sistema é menor em temperaturas menores, possibilitando a formação das estruturas secundárias e terciárias. 
Com esta estratégia foi possível a obtenção de proteína QM solúvel, em um enovelamento possivelmente correto, em concentrações adequadas aos experimentos de purificação, dicroísmo circular e fluorescência e com baixa quantidade de contaminantes bacterianos.

A purificação da proteína expressa no periplasma e extraída por sonicação, não teve bons resultados. A proteína por ser muito básica, com um pl teórico de 10, possivelmente seria de fácil purificação em coluna de troca catiônica, porem isto não aconteceu. Foram avaliados tampões com pHs próximos ao pl (Bicina $\mathrm{pH} 8,3$ ) que é sugerido pelo fabricante da coluna e com $\mathrm{pH}$ bem abaixo do pl (tris- $\mathrm{HCl} \mathrm{pH} 7,5$ ), que garantiria uma carga positiva a proteína se o pl teórico não fosse 10. Nestes experimentos ou a proteína não se ligava a resina ou quando era retida, ela era eluída com muitos contaminantes bacterianos, inviabilizando o procedimento.

As purificações utilizando a seqüência de histidina, presente na proteína, em cromatografia por afinidade a metal (Níquel e Cobalto), também não foram bem sucedidas. Neste caso há a possibilidade da seqüência de histidinas não estar exposta suficiente para se ligar ao Níquel ou Cobalto da coluna, visto que Nishimura e cols. (2006) não conseguiram o cristal da proteína QM íntegra porque a região C-terminal é muito flexível, impedindo a estruturação do cristal. A seqüência de histidinas está ligada à proteína QM pela região C-terminal, o que poderia explicar ausência de ligação desta à resina de afinidade por metal.

Quanto à proteína expressa no citoplasma, após a sonicação e centrifugação, as frações solúveis das temperaturas de $2^{\circ} \mathrm{C}$ e $300^{\circ} \mathrm{C}$, continha uma quantidade considerável de contaminantes (sp1). A inserção de outra etapa de centrifugação na extração possibilitou a obtenção de uma proteína QM mais pura. A primeira centrifugação, após a sonicação da cultura ativada, permitiu a separação, junto com a proteína QM, de proteínas solúveis da própria bactéria. Esse sobrenadante contendo a proteína QM, foi submetido a uma nova centrifugação. Na ressuspensão do precipitado resultante desta centrifugação, a proteína QM foi recuperada em menor concentração, 0,15 mg (sp2), porém sem os contaminantes solúveis da própria bactéria que haviam ficado no primeiro sobrenadante.

As amostras sp1 foram purificadas em coluna de exclusão molecular utilizando no tampão $\mathrm{NaCl}$ e as amostras sp2 já estavam praticamente sem 
contaminantes. Por ser uma proteína de eucarioto produzida em um sistema bacteriano, há a possibilidade desta, embora pura e solúvel, não estar necessariamente na sua conformação correta. Em vista disto, a proteína QM na forma solúvel e pura teve sua estrutura secundária analisada pela técnica de CD. Esta análise avalia a estrutura secundária na sua composição de $\alpha$-hélices, folhas $\beta$ e formas randômicas (sem conformação definida).

A primeira amostra analisada foi o produto obtido da purificação de QM por exclusão molecular, na qual a proteína foi eluída com $150 \mathrm{mM} \mathrm{NaCl}$. O perfil do CD obtido foi realmente surpreendente, pois mostrou uma proteína sem estruturas $\alpha$ ou $\beta$. De acordo com a literatura, tampões contendo sais, como $\mathrm{NaCl}$, são fortemente indicados para manter as cargas e a estabilidade conformacional de enzimas e proteínas (Andrade e cols., 1998). Estas amostras purificadas foram analisadas por dicroísmo circular e produziram um perfil de proteína sem conformação a ou $\beta$. Neste caso houve uma possível desestabilização, pois amostras semelhantes de QM, sem sal, foram analisadas e tiveram um perfil muito diferente.

Amostras da proteína QM das frações sp2, tanto cultivadas a 25 quanto a $30^{\circ} \mathrm{C}$, foram analisadas, também pela técnic a de CD e ocorreu uma diferença significativa entre as análises. A amostra de $25^{\circ} \mathrm{C}$ apresentou maior porcentagem de $\alpha$-hélice que a de $30^{\circ} \mathrm{C}$. A perda gradativa de $\alpha$-hélices e a concomitante detecção das folhas $\beta$, com a adição de concentrações crescentes de guanidina, foram mais lineares na amostras de $25^{\circ} \mathrm{C}$ do que as porcentagens encontradas para as amostras de $30^{\circ} \mathrm{C}$. Este fato den ota uma conformação secundária pouco estruturada. As conclusões de Vera e cols. (2007) para a GFP expressa em diferentes temperaturas corroboram com os dados encontrados para proteína QM, a qual também apresenta uma estrutura melhor definida como $\alpha$ hélices e folhas $\beta$, quando expressa em temperaturas menores, neste caso em $25^{\circ} \mathrm{C}$.

As análises da estrutura da proteína QM, sob a ação de concentrações crescentes de guanidina, obtidas por CD mostraram um perfil muito interessante de perda da estrutura.

A estrutura de $\alpha$-hélice possui a característica de ser mais resistente a ação de agentes denaturantes. Por estar localizada externamente à 
estrutura e possuir um tamanho maior quando comparado as folhas $\beta$ na proteína QM, pode-se inferir que a ação da guanidina agiu primeiramente na região externa da proteína e, após desestruturar a formação das duas $\alpha$-hélices, as folhas $\beta$ foram sendo expostas. Este fato pode ser observado pela diminuição gradativa da composição de $\alpha$-hélice e o concomitante aumento das folhas $\beta$, com o aumento da concentração de guanidina.

Um dos pontos intrigantes neste trabalho, sem dúvida nenhuma, foi a ausência de retenção da amostra periplásmica, que foi testada em resinas de princípios diferentes como afinidade e troca catiônica, e ausência de enovelamento correto na amostra solúvel obtida a partir das culturas de $25^{\circ} \mathrm{C}$ e $30^{\circ} \mathrm{C}$ (sp1). Avaliando-se os resultados dos CDs obtidos pelas amostras de proteína citoplásmica (sp2) cultivadas nestas duas temperaturas, pode-se perceber que estes possuem diferenças significativas: (i) a porcentagem de $\alpha$ hélice é maior na amostra cultivada a $25^{\circ} \mathrm{C}$; (ii) na curva de guanidina a perda gradual do enovelamento, particularmente das $\alpha$-hélices e exposição das folhas $\beta$, foi mais acentuado na amostra cultivada a $25^{\circ} \mathrm{C}$ e; (iii) o desenovelamento da amostra cultivada a ${ }^{2} 5^{\circ} \mathrm{C}$, com a adição de guanidina, foi praticamente linear, enquanto que o observado na amostra cultivada a $30^{\circ} \mathrm{C}$ não. Este fenômeno foi observado tanto para a perda nas $\alpha$-hélices como na detecção das folhas $\beta$.

Observa-se nitidamente que temperaturas mais altas $\left(3^{\circ} \mathrm{C}\right)$ podem propiciar um enovelamento incorreto, porém mantendo a proteína solúvel. Isto poderia ter ocorrido no caso da proteína produzida no periplasma, na qual a temperatura de cultivo foi $37^{\circ} \mathrm{C}$.

Os dados obtidos nos espectros de fluorescência com as amostras contendo concentrações crescentes de guanidina mostraram um aumento na emissão de fluorescência. As maiores detecções foram nos comprimentos de onda entre $\lambda 335$ a $337 \mathrm{~nm}$, tanto para a proteína obtida em $25^{\circ} \mathrm{C}$ quanto para a de $30^{\circ} \mathrm{C}$. O comprimento de onda esperado para a emis são de fluorescência do triptofano é de $\lambda 360 \mathrm{~nm}$, porém este não foi detectado neste experimento. Podese inferir que as altas quantidades de aminoácidos, que emitem fluorescência na faixa de comprimento de onda medido, é bastante grande, (11 Tirosinas e 9 Fenilalanina) isto poderia alterar 0 espectro. A estrutura secundária foi evidenciada por análise de CD, onde a perda da conformação da proteína ocorre 
em etapas, isto é, o desenovelamento das $\alpha$-hélices e concomitante exposição das folhas $\beta$. Os aminoácidos que estão distribuídos ao longo da molécula poderiam emitir uma fluorescência resultante diferente em cada etapa deste desenovelamento. Acreditamos que um trabalho mais detalhado, visando à análise separadamente de cada um dos aminoácidos que emitem fluorescência em seus comprimentos de ondas específicos, poderia fornecer dados mais elucidativos a respeito da estrutura terciária da molécula.

Os espectros obtidos nas análises de incorporação de Zinco seguiram o mesmo padrão obtido para os experimentos com guanidina. Cabe aqui observar que alguma mudança deve estar ocorrendo, pois a alteração observada entre a emissão com e sem Zinco é bastante significativa. Este fato nos leva a crer que esteja havendo uma alteração na conformação da molécula, o que seria o esperado, pois é neste sítio que a proteína interage com a oncoproteína Jun (Zhang e cols., 2004).

A proteína recombinante QM solúvel foi expressa nas duas vias de expressão escolhidas, sendo eficiente apenas no citoplasma bacteriano, esta foi purificada com sucesso, mas em compensação teve sua conformação estrutural modificada pelo sal acrescentado à amostra. Em cultivo a baixas temperaturas, esta proteína foi obtida na forma solúvel. A partir desta etapa, a proteína foi submetida aos ensaios de estrutura com a obtenção dos perfis de estrutura secundária bem como a análise dos triptofanos presentes na mesma. 


\section{CONCLUSÕES}

Este trabalho propôs a expressão da proteína recombinante QM solúvel, sua purificação e análises estruturais.

- O cDNA para QM foi clonado em vetor de expressão periplásmica P3SN8 mas não houve sucesso na obtenção da proteína.

- As bactérias transformadas pelo vetor pET26_QM, também de expressão periplásmica, produziram cerca de $0,13 \mathrm{mg} / \mathrm{ml}$ de proteína recombinante QM. Porém nenhum choque osmótico testado foi eficiente para retirada da proteína;

- A expressão com o plasmídeo recombinante p1813_QM teve os maiores níveis de proteína solúvel obtidos em culturas incubadas a $25^{\circ} \mathrm{C}$ e $30^{\circ} \mathrm{C}$ por $16 \mathrm{~h}$, não haven do diferença significativa entre as duas;

- A quantidade de proteína obtida a partir da cultura transformada pelo plasmídeo p1813_QM foi de $1,4 \mathrm{mg} / \mathrm{mL}$ de meio;

- A proteína QM solúvel obtida foi de $0,2 \mathrm{mg} / \mathrm{mL}$ numa fração praticamente sem contaminantes, não havendo necessidade de purificação;

- A proteína possui uma conformação estrutural secundária definida;

- Os testes de estabilidade com guanidina demonstraram que esta é composta por $\alpha$-hélice e folha beta;

- A estrutura em $\alpha$-hélice se encontra na região externa da proteína evidenciada pela desenovelamento da molécula;

- Os resultados de fluorescência obtidos com desenovelamento da molécula por guanidina não foram conclusivos. 


\section{REFERÊNCIAS}

ANGEL, P.; KARIN, M. The role of Jun, Fos and the AP-1 complex in cellproliferation and transformation. Biochimica et biophysica Acta, v. 1072, p. 12957, 1991.

ALTINOK, G.; POWEL, I.J.; CHE, M.; HORMONT, K.; SARKAR, F.H.; SAKR, W.A.; GRIGNON, D.; LIAO, D.J. Reduction of QM protein expression correlates with tumor grade in prostatic adenocarcinoma. Prostate cancer and prostatic disease, v. 9 (1), p. 77-82, 2006.

ANDRADE, M.C.C; QUINTO, B.M.; CARMONA, A.K.; RIBAS, O.S.; BOIM, M.A.; SCHOR, N.; CASARINI, D.E. Purification and characterization of angiotensin Iconverting enzymes from mesangial cells in culture. Journal of hypertension, $v$. 16, p. 2063-74, 1998.

BAYER, M.E., LEIVE, L. Effect of ethylenediaminetetraacetate upon the surface of Escherichia coli. Journal of bacteriology, v 130 (3), p. 1364-81, 1977.

BOHM, G.; MUHR, R.; JAENICKE, R. Quantitative analysis of protein far UV circular dichroism spectra by neural networks. Protein engeneering, v. 5, p. 19195, 1992.

BRADFORD, M.M. A rapid and sensitive method for the quantitation of microgram quantities of protein utilizing the principle of Protein-Dyue binding. Analytical biochemistry, v. 72, p. 248-54, 1976.

BISHOP, J.M. Molecular themes in oncogenesis. Cell Review, v. 64, p. 235-46, 1991.

BORJALILOO, S.; ZOMORODIPOUR, A.; YAKHCHALI, B.; SHOJAI, S. Comparison of T7- and lac-based systems for the periplasmic expression of human granulocyte macrophage colony stimulating factor in Escherichia coli.

Iranian Journal of Biotechnology, v. 1 (2), p. 101-108, 2003.

BURNERTTE, W.N. "Western Blotting": Eletrophoretic transfer of proteins form Sodium Dodecyl Sulfate-Polyacrilamide gels to unmodified nitrocellulose and radiographic detection with antibody and radioiodinate protein A. Analytical biochemistry, v. 112, p. 195-203, 1981.

CLARK, E.D. Protein refolding for industrial processes. Current opinion in biotechnology, v. 12 (2), p. 202-7, 2001.

COOPER, G.M. Tumor Suppressor Genes-The Cell-A Molecular Approach 2nd, Sunderland (MA): Sinauer Associates, Inc; c2000. 
DOWDY, S.F.; LAI, K.M.; WEISSMAN, B.E; MATSUI, Y.; HOGAN, B.L.M.; STANBRIDGE, E.J. The isolation and characterization of a novel cDNA demonstrating an altered mRNA level in nontumorigenic Wilms' microcell hybrid cells. Nucleic acids research, v. 19 (20), p. 5763-69, 1991.

FARMER, A.A.; JOHNSEN, J.I.; LOFTUS, T.M.; SMITH, K.P.; STANBRIDGE, E.J. Isolation and characterization of the QM promoter. Nucleic acids research, v. 24 (11), p. 2158-65, 1996.

FUTREAL, P.A.; COIN, L.; MARSHALL, M.; DOWN, T.; HUBBARD, T.; WOOSTER, R.; RAHMAN, N.; STRATTON, M. A census of human cancer genes. Nature reviews Cancer, v. 4 (3), p. 177-83, 2004.

GRAHAM, R. W.; GREENWOOD, J. M.; WARREN, R. A.; KILBURN, D. G.; A TRIMBUR, D. E. The pTug A and pTug as vectors for the high-level expression of cloned genes in Escherichia coli. Gene, v. 158, p. 51-54, 1995.

GODEFROY, N.; LEMAIRE, C.; MIGNOTTE, B.; VAYSSIÈRE, J.L. p53 and Retinoblastoma protein (pRb): A complex network of interactions. Apoptosis, v. 11, p. 659-61, 2006.

HANAHAN, D.; WEINBERG, R.A. The hallmarks of cancer. Cell, v. 100, p. 57-70, 2000.

HIGGINS, J.A.; BARRNETT, R.J., Studies on the biogenesis of smooth endoplasmic reticulum membranes in livers of Phenobarbital treated rats - The site of activity of acetyltransferases involved in synthesis of the membrane phospholipid. The Journal of cell biology, v. 55 (2), p. 282-98, 1972.

HUNTER, T. Cooperation between oncogenes. Cell Review, v. 64, p. 249-70, 1991.

KOSHLAND, D.; BOTSTEIN, D. Secretion of beta-lactamase requires the carboxy end of the protein. Cell, v. 20, p. 331-34, 1997.

LAEMMLI, U. K. Cleavage of structural proteins during the assembly of the head of bacteriophage T4. Nature, v. 227, p. 680-85, 1970.

LOFTUS, T.M.; NGUYEN, Y.H.; STANBRIDGE, E. J. The QM protein associates with ribosomes in the rough endoplasmic reticulum. Biochemistry, v. 36, p. 822430, 1997.

LUCK, D. N.; GOUT, P. W.; BEER, C. T.; SMITH, M. Bioactive recombinant methionyl bovine prolactin: structure-function studies using site-specific mutagenesis. Molecular Endocrinology, v. 3 (5), p. 822-831, 1989.

MALUMBRES, M.; BARBACID, M. To cycle or not to cycle: A critical decision in cancer. Nature reviews Cancer, v. 1, p. 222-31, 2001. 
MAKRIDES, S.C. Strategies for achieving high-level expression of genes in Escherichia coli. Microbiological reviews, v. 60, p. 512-538, 1996.

MASSAD-COSTA, A.M.; DA SILVA, I.D.C.; AFFONSO, R.; SOARES JR, J.M.; NUNES, M.G.; DE LIMA, G.R.; BARACAT, E.C. Gene analysis in patients with premature ovarian failure or gonadal dysgenesis: A preliminary study. Maturitas, v. 57, p. 399-404, 2007.

MATSUSHITA K.; SHINAGAWA E.; ADACHI O.; AMEYAMA M. Spheroplast of acetic acid bacteria. Agricultural and biological chemistry, v. 45 (6), p. 1515-18, 1981.

MEIRELES, S.I.; CARVALHO, A.F.; HIRATA, J.R.R; MONTAGNINI, A.L. Differentially expressed genes in gastric tumors identified by cDNA array. Cancer letters, v. 190, p. 199-211, 2003.

MONTECLARO, F.S.; VOGT, P.K. A Jun-binding protein related to a putative tumor suppressor. Cell Biology, v. 90, p. 6726-30, 1993.

MORGANTI, L.; HUYER, M.; GOUT, P.W.; BARTOLINI, P. Production and characterization of biologically active Ala-Ser-(His)6-Ile-Glu-Gly-Arg-human prolactin (tag-hPRL) secreted in the periplasmic space of Escherichia coli. Biotechnology and applied biochemistry, v. 23, p. 67-75, 1996.

NGUYEN, Y.H.; MILLS, A.A.; STANBRIDGE, E.J. Assembly of the QM protein onto the 605 ribosomal subunit occurs in the cytoplasm. Journal of Cellular Biochemistry, v. 68, p. 281-285, 1998.

NOWELL, P.C. Mechanisms of tumor progression. Cancer research, v. 46, p. 2203-07, 1986.

OH, H.S.; KWON, H.; SUN, S.K.; YANG, C.H. QM, a putative tumor suppressor, regulates proto-oncogene c-Yes. The Journal of biological chemistry, v. 277 (39), p. 36489-98, 2000.

PEDRAZA-FARIÑA, L.G. Mechanisms of oncogenic cooperation in cancer initiation and metastasis. Yale Journal of Biology and Medicine, v. 79, p. 95103, 2006.

QORONFLEH, M.W.; HESTERBERG, L.K. Confronting high-troughput protein refolding using high pressure and solution screens. Protein expression and purification, v. 55, p. 209-24, 2007.

RATHORE, A.S.; BILBREY, R.E.; STEINMEYER D.E. Optimization of an osmotic shock procedure for isolation of a protein product expressed in $E$. coli. Biotechnology Progress, v 19 (5), p. 1541-1546, 2003.

ROSKOSKI, R.JR. Src protein-tyrosine kinase structure and regulation. Biochemical and Biophysical Research Communications, v. 324 (4), p. 115564, 2004. 
SEFFRIN, J.R.; HILL, D.; BURKART, W.; MAGRATH, I.; BADWE, R. A., NGOMA, T.; MOHAR, A.; GREY, N. Millennium development goals. CA: a cancer journal for clinicians, v. 59, p. 282-84, 2009.

SHEN, X. J.; ALI-FEHMI, R.; WENG, C.R.; SARKER, F.H.; GRIGNON, D.; LIAO, D.J. Loss of heterozygosity and microsatellite instability all the Xq28 and the A/G heterozygoty of the QM gene are associated with ovarian cancer. Cancer Biology \& Therapy, v. 5 (5), p. 523-8, 2006.

SILVA, L. R. Estudo da renaturação da proteína antitumoral QM por meio de altas pressões. 2008. Trabalho de Conclusão de Curso- Universidade Bandeirante de São Paulo, São Paulo.

SOARES, C.R.J.; GOMIDE, F.I.C.; UEDA, E.K.M.; BARTOLINI, P. Periplasmic expression of human growth hormone via plasmid vectors containing the IPL promoter: use of HPLC for product quantification. Protein Engineering, v. 16 (12), p. 1131-38, 2003

SØRENSEN, P. H.; MORTENSEN, K. K. Soluble expression of recombinant proteins in the cytoplasm of Escherichia coli. Microbial Cell Factories, v. 4 (1), p. $1-8,2005$.

VERA, A.; GONZÁLEZ-MONTALBÁN, N.; ARÍS, A.; VILLAVERDE A. The conformational quality of insoluble recombinant proteins is enhanced at low growth temperatures. Biotechnology and bioengineering, v. 96 (6), p. 1101-6, 2007.

ZHANG, Y.; HUNAG, J.; MENG, Q.; JIANG, T.; XIE, L.;WANG, Z.; ZHANG, R. Molecular cloning and expression of pearl oyster (Pincatada fucata) homologue of mammalian putative tumor suppressor QM. Marine Biotechnology, v. 6, p. 8-16, 2004. 